Report of Investigation 2019-1

\title{
TSUNAMI INUNDATION MAPS FOR ADAK AND ATKA, ALASKA
}

E.N. Suleimani, J.B. Salisbury, D.J. Nicolsky, and M.E. West

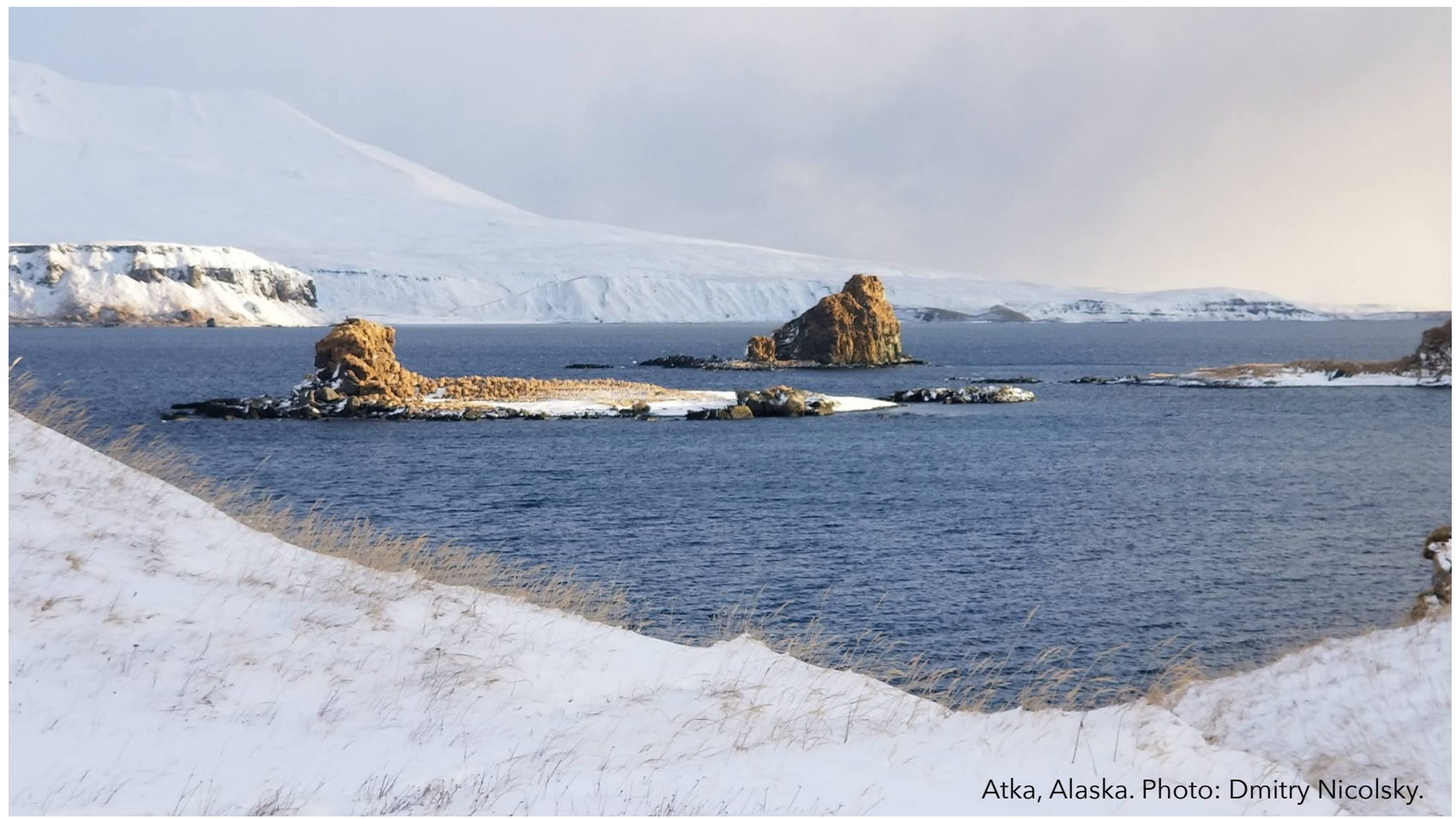





\section{TSUNAMI INUNDATION MAPS FOR ADAK AND ATKA, ALASKA}

E.N. Suleimani, J.B. Salisbury, D.J. Nicolsky, and M.E. West

Report of Investigation 2019-1

State of Alaska

Department of Natural Resources

Division of Geological \& Geophysical Surveys 
STATE OF ALASKA

Michael J. Dunleavy, Governor

\section{DEPARTMENT OF NATURAL RESOURCES}

Corri A. Feige, Commissioner

\section{DIVISION OF GEOLOGICAL \& GEOPHYSICAL SURVEYS}

Steve Masterman, State Geologist and Director

Publications produced by the Division of Geological \& Geophysical Surveys (DGGS) are available for free download from the DGGS website (dggs.alaska.gov). Publications on hard-copy or digital media can be examined or purchased in the Fairbanks office:

Alaska Division of Geological \& Geophysical Surveys 3354 College Rd., Fairbanks, Alaska 99709-3707

Phone: (907) 451-5010 Fax (907) 451-5050

dggspubs@alaska.gov|dggs.alaska.gov

DGGS publications are also available at:

Alaska State Library,

Historical Collections \& Talking Book Center

395 Whittier Street

Juneau, Alaska 99811

Alaska Resource Library and Information Services (ARLIS)

3150 C Street, Suite 100

Anchorage, Alaska 99503

Suggested citation:

Suleimani, E.N., Salisbury, J.B., Nicolsky, D.J., and West, M.E., 2019, Tsunami inundation maps for Adak and Atka, Alaska: Alaska Division of Geological \& Geophysical Surveys Report of Investigation 2019-1, 63 p., 6 sheets. doi.org/10.14509/30186
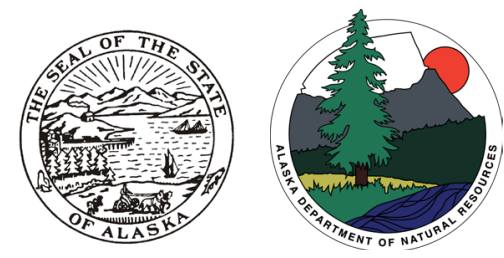


\section{Contents}

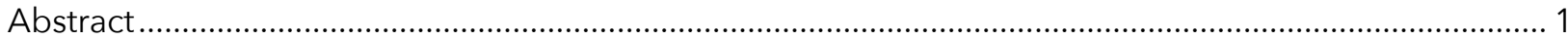

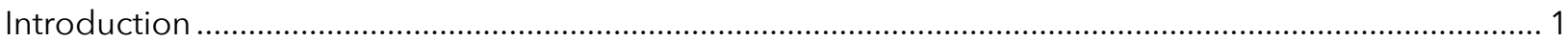

Project Background: Regional \& Geological Context ........................................................................ 1

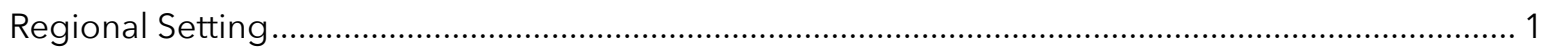

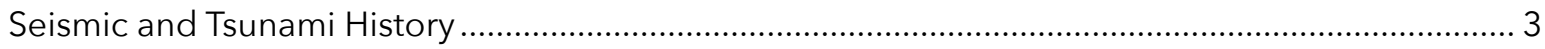

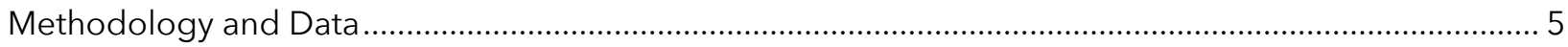

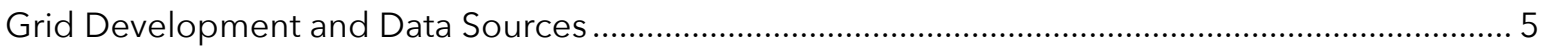

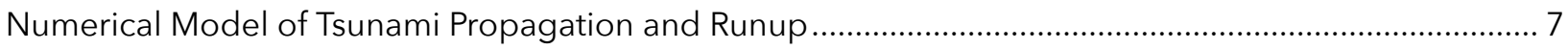

Validation of the Model with the March 11, 2011, Tohoku Tsunami.............................................. 8

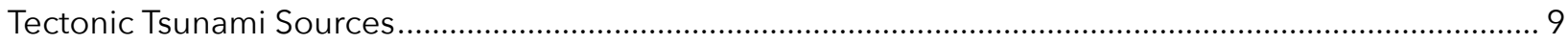

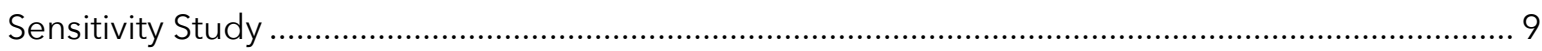

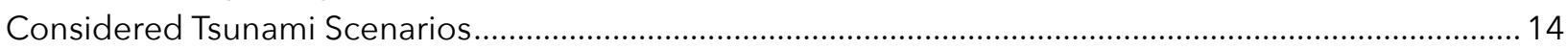

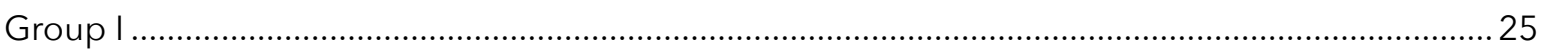

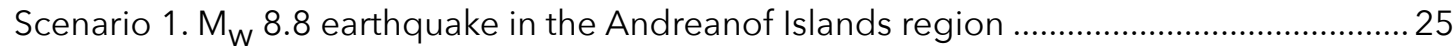

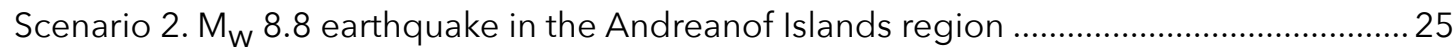

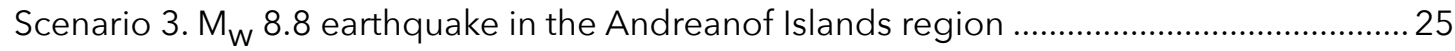

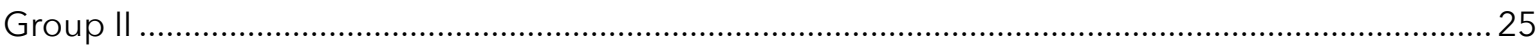

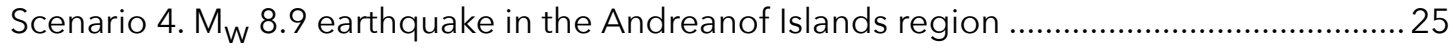

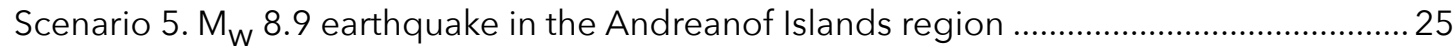

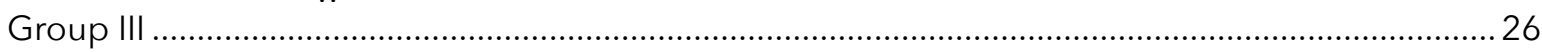

Scenario 6. $\mathrm{M}_{\mathrm{W}} 9.1$ earthquake in the Andreanof Islands region ..........................................26

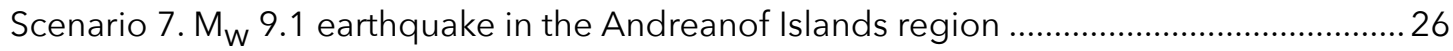

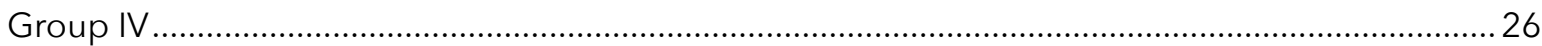

Scenario 8. $\mathrm{M}_{\mathrm{W}} 9.0$ earthquake according to the SAFRR project ..........................................26

Scenario 9. $M_{W} 9.1$ earthquake in the Cascadia subduction zone along the British Columbia, Washington, Oregon, and northern California shores .......................... 27

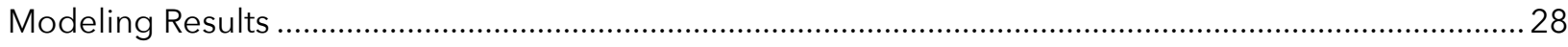

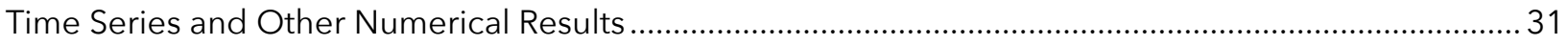

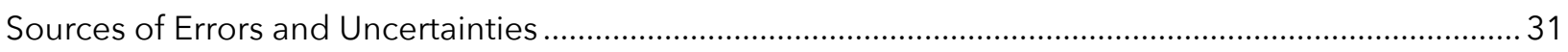

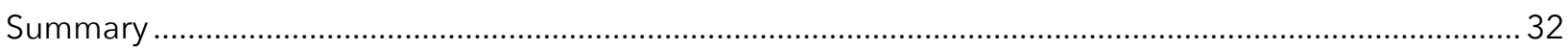

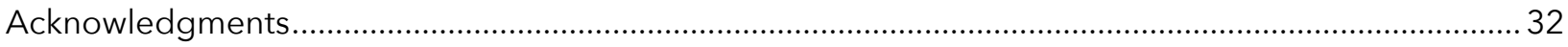

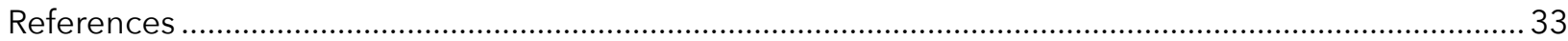

\section{Figures}

Figure 1. Map of the central Aleutian Islands and the Andreanof Islands group ..................................... 2

Figure 2. Updated dislocation modeling results for Andreanof Islands region ....................................... 3

Figure 3. Nesting of the levels 0-4 bathymetry/topography grids for numerical modeling of

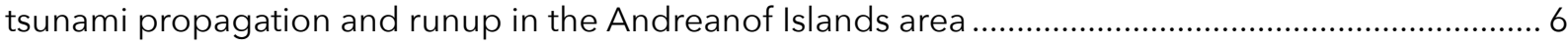

Figure 4. Locations of real-time kinetic GPS measurements in Adak ....................................................... 7

Figure 5. Locations of RTK GPS measurements in Atka ........................................................................ 8

Figure 6. Observed water-level dynamics in Adak and GPS measurements of water level in the

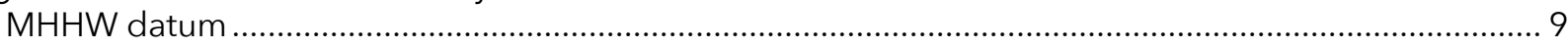

Figure 7. Map of vertical deformations of the ocean floor and adjacent coastal region corresponding to the March 11, 2011, Tohoku earthquake ................................................................ 10

Figure 8. Observed and simulated water-level dynamics at the Adak tide station during the 14-hour period following the March 11, 2011, Tohoku earthquake .................................................... 11

Figure 9. Mosaic of the discretized plate interface in the area of Andreanof Islands used for construction of hypothetical ruptures 
Figure 10. Hypothetical slip distributions and vertical coseismic deformations along the plate interface for cases $A-E$, modeling $M_{w} 8.0$ ruptures offshore Adak.....

Figure 11. Hypothetical slip distributions and coseismic deformations along the plate interface for cases $\mathrm{A}-\mathrm{Ez}$, modeling $\mathrm{M}_{\mathrm{w}} 8.0$ ruptures offshore Atka.

Figure 12. Modeled water-level dynamics for the vertical coseismic deformations......

Figure 13. Estimated slip distributions and computed vertical coseismic deformations along the plate interface for scenarios 1-7 for Adak.

Figure 14. Estimated slip distributions and computed vertical coseismic deformations along the plate interface for scenarios 1-7 for Atka

Figure 15. Computed vertical coseismic deformations for scenario 8 , a $M_{W} 9.0$ earthquake according to the SAFRR project......

Figure 16. Computed vertical coseismic deformations for scenario 9 , a $M_{W} 9.1$ earthquake in the Cascadia subduction zone

Figure 17. Modeled potential inundation in Adak for selected scenarios

Figure 18. Modeled potential inundation in Atka for selected scenarios 30

\section{Tables}

Table 1. Tsunami effects at Adak and Atka...

Table 2. Nested grids used to compute propagation of tsunami waves from the Pacific to Adak and Atka 5

Table 3. Hypothetical tectonic scenarios used to model tsunami runup in Adak and Atka........ 18

\section{Appendix}

Figure A1. Locations of time series points in Adak.

Table A1. Maximum water levels and water velocities for tectonic scenarios at time series points near Adak

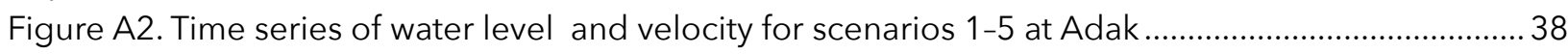

Figure A3. Time series of water level and velocity for scenarios 6 and 7 at Adak ................................ 43

Figure A4. Time series of water level and velocity for scenarios 8 and 9 at Adak ...................................48

Figure B1. Locations of time series points in Atka ................................................................................ 53

Table B1. Maximum water levels and water velocities for tectonic scenarios at time series

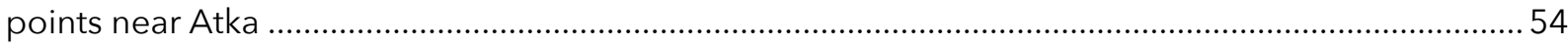

Figure B2. Time series of water level and velocity for scenarios 1-5 at Atka .......................................55

Figure B3. Time series of water level and velocity for scenarios 6-7 at Atka.......................................... 58

Figure B4. Time series of water level and velocity for scenarios 8 and 9 at Atka ..................................61

\section{Map Sheets}

Sheet 1. Maximum estimated tsunami inundation, Adak, Alaska

Sheet 2. Potential maximum permanent flooding, Adak, Alaska

Sheet 3. Maximum estimated tsunami inundation, Atka, Alaska

Sheet 4. Maximum estimated tsunami inundation and potential permanent flooding, North Atka, Alaska

Sheet 5. Maximum estimated tsunami inundation and potential permanent flooding, South Atka, Alaska

Sheet 6. Potential maximum permanent flooding, Atka, Alaska 


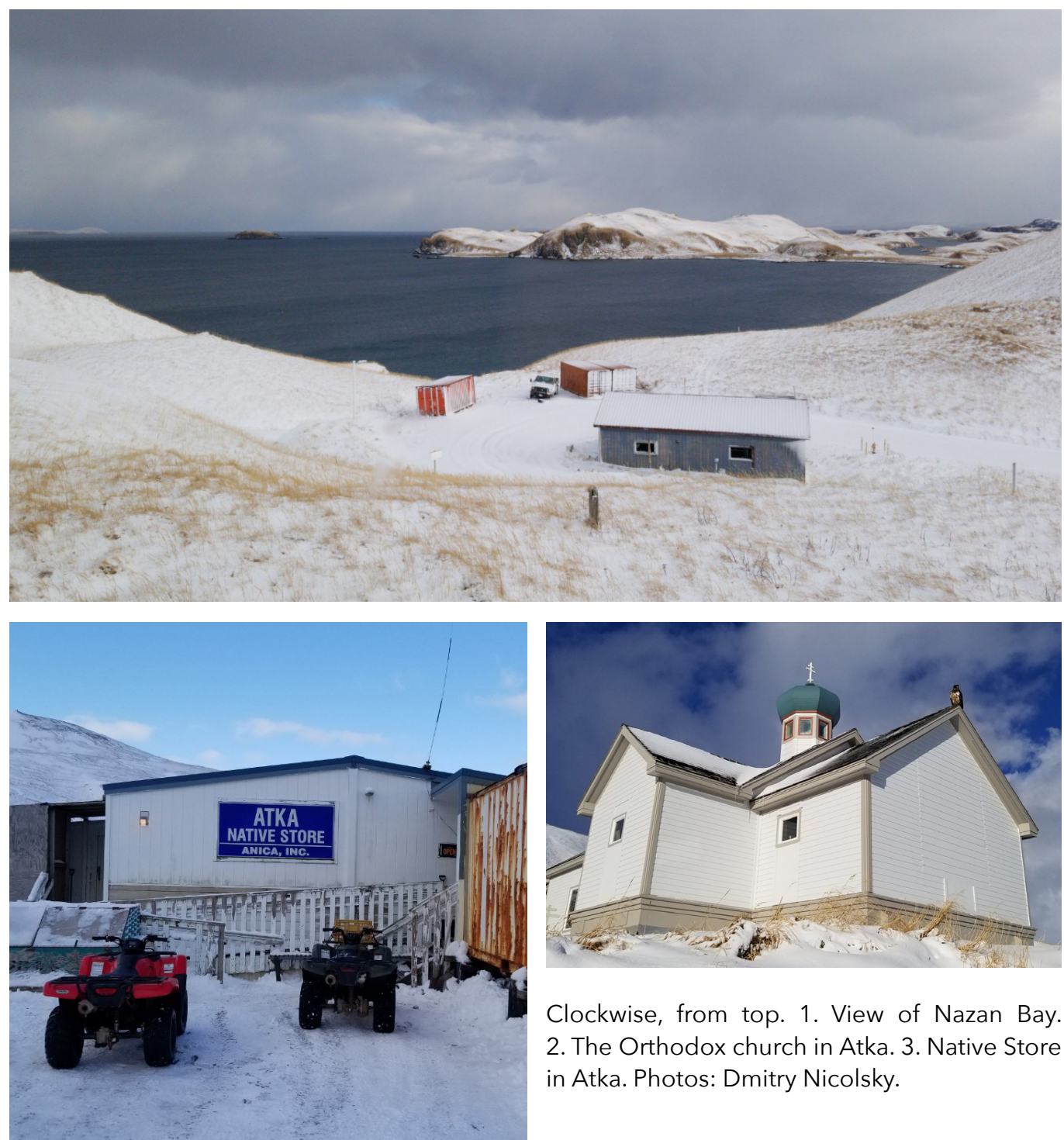

Clockwise, from top. 1. View of Nazan Bay. 2. The Orthodox church in Atka. 3. Native Store in Atka. Photos: Dmitry Nicolsky. 


\title{
TSUNAMI INUNDATION MAPS FOR ADAK AND ATKA, ALASKA
}

\author{
E.N. Suleimani, ${ }^{1}$ J.B. Salisbury, ${ }^{2}$ D.J. Nicolsky, ${ }^{1}$ and M.E. West ${ }^{1}$
}

\begin{abstract}
We evaluate potential tsunami hazard for Adak and Atka by numerically modeling tsunami inundation generated by earthquakes along the Alaska-Aleutian subduction zone. Hypothetical worst-case scenarios are defined by analyzing tsunami dynamics related to various plausible earthquake slip distributions. Potential tsunami sources include megathrust earthquakes in the area of the Andreanof Islands, the Alaska Peninsula, and the Cascadia subduction zone. We consider scenarios similar to the 2011 Tohoku earthquake in Japan with maximum slip located on a shallow portion of the plate interface close to the seafloor trench. The maximum modeled tsunami wave height is 10-15 m (33-50 ft) in both Adak and Atka. The numerical simulations reveal that for some scenarios, the first wave could reach Adak and Atka as soon as 15 and 30 minutes after the earthquake, respectively. Significant wave activity could continue for more than 12 hours after the earthquake, and the predicted average time interval between successive waves is 45 minutes to 1 hour. Results presented here are intended to provide guidance to local emergency management agencies for tsunami inundation assessment, evacuation planning, and public education to mitigate future tsunami hazards.
\end{abstract}

\section{INTRODUCTION}

Subduction of the Pacific plate under the North American plate has resulted in numerous great earthquakes $(M>8)$ and is the source of locally generated tectonic tsunamis in Alaska (Dunbar and Weaver, 2008). Several historic earthquakes along the Alaska-Aleutian megathrust (fig. 1) have generated tsunamis resulting in widespread damage and loss of life in Alaska and throughout the Pacific (Lander, 1996). Tsunamis originating in the vicinity of the Aleutian Islands are a near-field hazard and can reach coastal communities within minutes of an earthquake. However, property damage and loss of life can potentially be minimized through strong community awareness and preparedness programs. Estimating the potential flooding, or "inundation," in the coastal zone with numerical models is an essential component of these programs.
The intended audience of this report consists of scientists, engineers, and community planners. Digital data and documentation provided with the report enable technical users to explore the range of potential tsunami impacts. The methods used to produce tsunami inundation maps were developed over the course of many years in multiple publications. Refer to Suleimani and others (2016) for a summary of the current methodology.

\section{PROJECT BACKGROUND: REGIONAL \& GEOLOGICAL CONTEXT \\ Regional Setting}

The following regional information is paraphrased from the Community Database, Alaska Department of Commerce, Community, and Economic Development's Division of Community and Regional Affairs (DCCED/DCRA).

\footnotetext{
'Alaska Earthquake Center, Geophysical Institute, University of Alaska, P.O. Box 757320, Fairbanks, Alaska 99775-7320; ensuleimani@alaska.edu

${ }^{2}$ Alaska Division of Geological \& Geophysical Surveys, 3354 College Rd., Fairbanks, Alaska 99709-3707.
} 


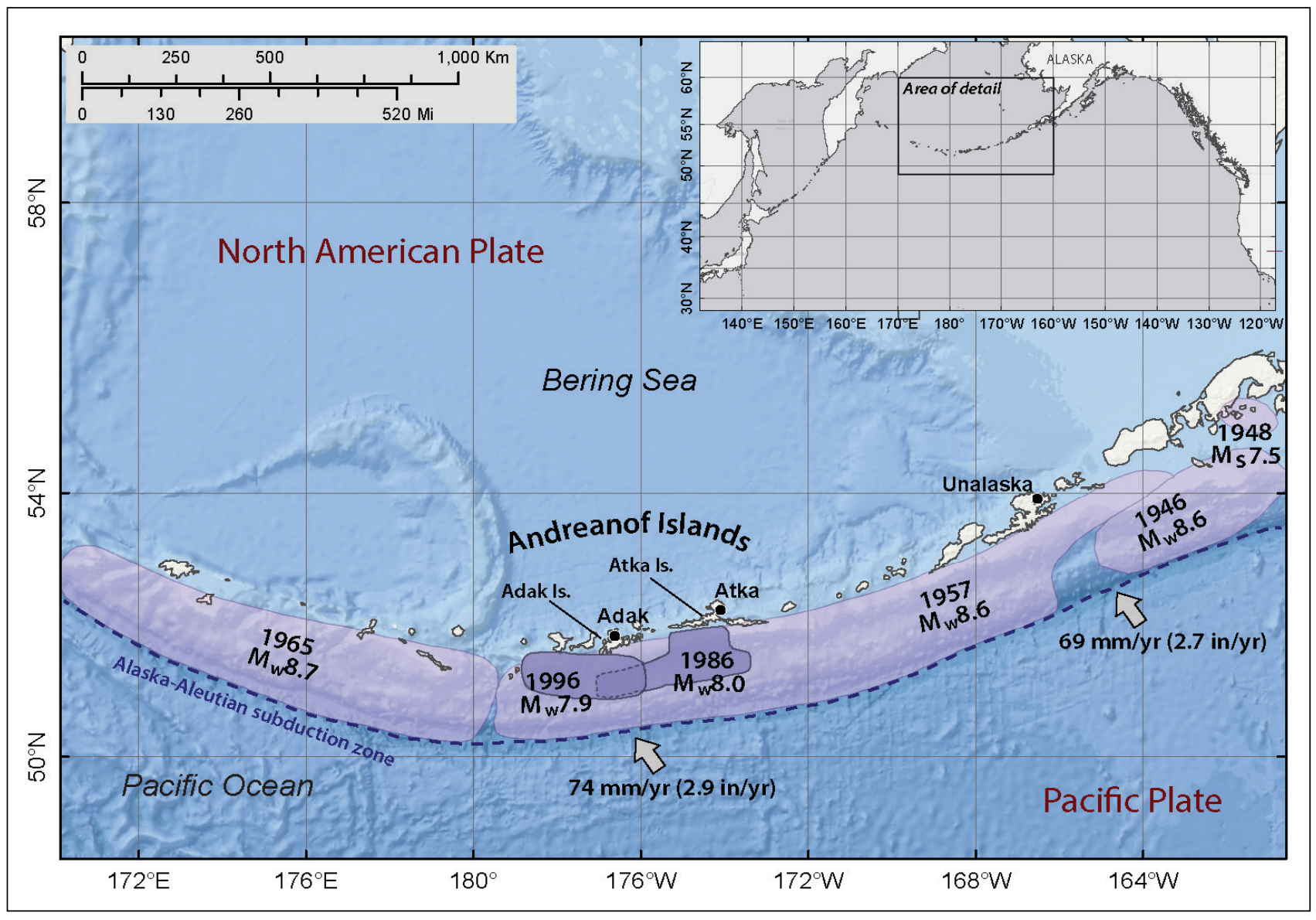

Figure 1. Map of the central Aleutian Islands and the Andreanof Islands group. Rupture areas of the latest sequence of great and large earthquakes are shown by shaded polygons.

Adak (51 $\left.53^{\prime} 0^{\prime \prime} \mathrm{N}, 176^{\circ} 38^{\prime} 42^{\prime \prime} \mathrm{W}\right)$, population 308, is located on Adak Island in the Andreanof Islands (fig. 1). It is $1,930 \mathrm{~km}(1,200 \mathrm{mi})$ southwest of Anchorage and $724 \mathrm{~km}(450 \mathrm{mi})$ west of Dutch Harbor (Unalaska). Adak Island, once heavily populated, was abandoned in the early 1800s as Aleutian Islands hunters followed the Russian fur trade east. During World War II, Adak's military installations allowed U.S. forces to mount successful military operations. After the war, Adak was developed as a naval air station, which closed on March 31, 1997. In 2001, the community became an incorporated city. Adak currently provides a fueling port and crew transfer facility for fishing ships based in Seattle and Alaska. The community has an airport, docks, housing facilities, a restaurant, grocery store, and ship supply store. Adak Fisheries, LLC, an employer of a large seasonal staff, processes Pacific cod, pollock, mackerel, halibut, and snow and king crab.

Atka (52 $\left.11^{\prime} 57^{\prime \prime} \mathrm{N}, 174^{\circ} 12^{\prime} 48^{\prime \prime} \mathrm{W}\right)$, population 70 , is on the east side of Atka Island in the Andreanof Islands (fig. 1). It is $1,770 \mathrm{~km}(1,100$ mi) southwest of Anchorage, $563 \mathrm{~km} \mathrm{(350} \mathrm{mi)} \mathrm{west}$ of Dutch Harbor (Unalaska), and 172 km (107 mi) east of Adak. Atka is a traditional Unangan (Aleut) community and a federally recognized tribe. According to DCCED/DCRA, the island has been occupied by Unangans for at least 2,000 years. The first contact with Russian explorers occurred in 1747, and Atka became an important trade site and safe harbor. During World War II, Atka was burned to the ground but was rebuilt by the U.S. Navy after the war, at which time residents were allowed to return. The city was incorporated in 1988 and has an airport, docks, and housing 
facilities. Scheduled air service is available three times weekly from Unalaska, and planes can also be chartered from Cold Bay or Unalaska.

\section{Seismic and Tsunami History}

The Andreanof Islands are part of the Aleutian Arc, north of the convergent boundary between the Pacific and North American plates known as the Alaska-Aleutian subduction zone (fig. 1). The plate convergence rate near the Andreanof Islands is approximately $74 \mathrm{~mm}$ (2.9 in) per year (Cross and Freymueller, 2007). This section of subduction zone has ruptured in three major earthquakes in the last -60 years (fig. 1). The $1957\left(\mathrm{M}_{\mathrm{W}}\right.$ 8.6) earthquake initiated near the Andreanof Islands and ruptured east toward Unalaska (Johnson and others, 1994). The damages to Adak and Atka from both the earthquake and resulting tsunami were severe. The 1986 Andreanof Islands earth- quake $\left(\mathrm{M}_{\mathrm{W}}\right.$ 8.0) and the 1996 event $\left(\mathrm{M}_{\mathrm{W}}\right.$ 7.9) together re-ruptured the western one-third of the 1957 rupture area. The 1996 rupture area is west of and slightly overlaps the 1986 rupture area (fig. 1; Tanioka and Gonzalez, 1998).

Cross and Freymueller (2007) used GPS measurements to study plate coupling in the Andreanof region of the subduction zone and found strong along-strike (i.e., - east-west) variations in plate coupling. They showed that the combined rupture area of the 1986 and 1996 earthquakes was a region of high slip deficit. This combined rupture area had high slip during the 1957 earthquake (Johnson and others, 1994). Cross and Freymueller (2008) found that the plate interface is nearly 100 percent locked west of the 1986 and 1996 earthquakes at depths from $15-45 \mathrm{~km}$ (9-28 mi), and that east of the 1986 earthquake the subduction zone is largely creeping (fig. 2).

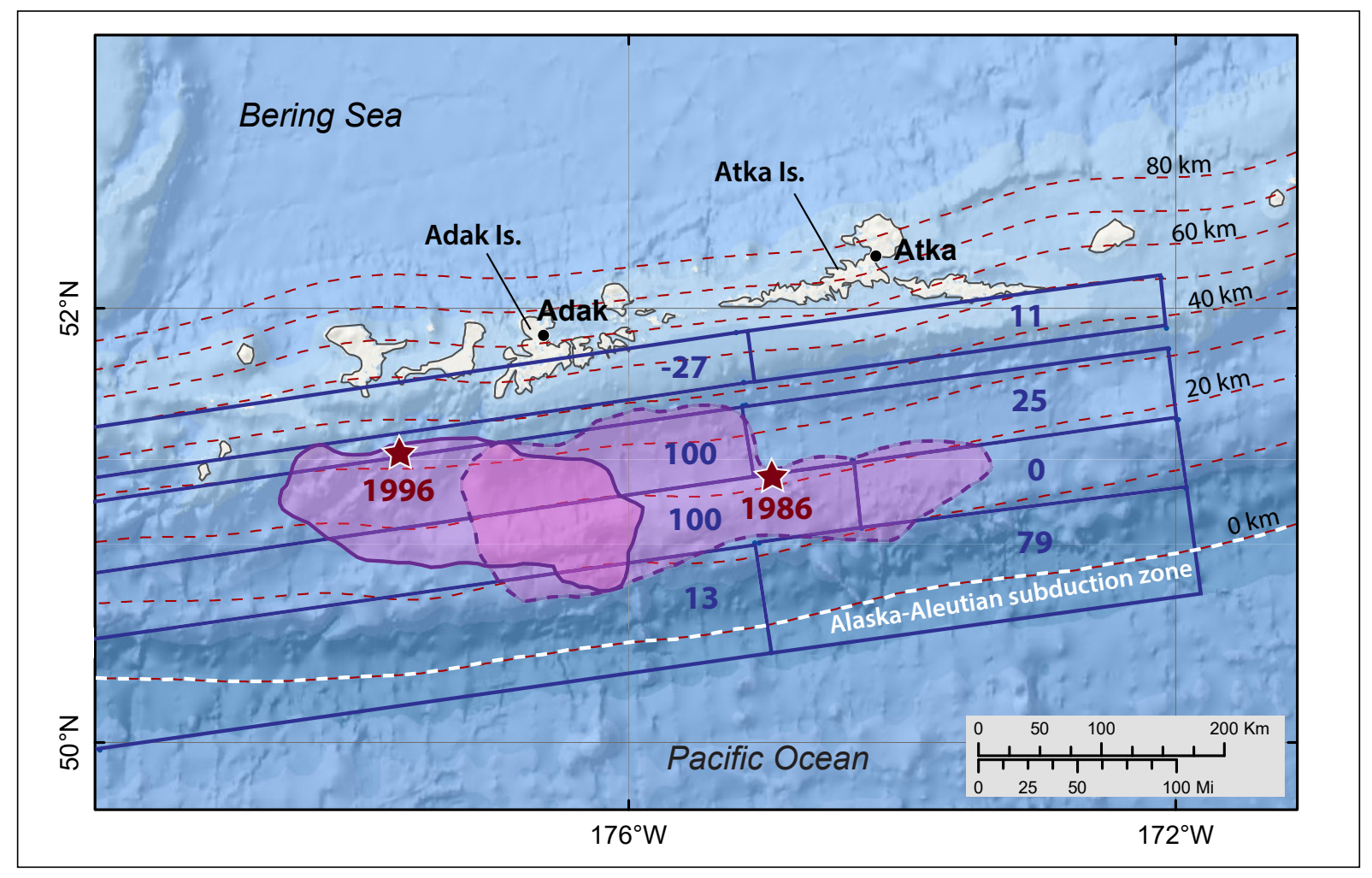

Figure 2. Updated dislocation modeling results for Andreanof Islands region, adapted from Cross and Freymueller (2008). Bold blue numbers indicate the percentage of unit coupling for the associated fault plane. Epicenters of the 1986 and 1996 earthquakes are shown as stars, with the rupture areas shaded. Red lines are depth contours of the subducting plate interface; black numbers indicate depth in kilometers from the ocean floor to the interface. The approximate location of the trench is shown by the white dashed line. 
According to the National Geophysical Data Center Global Historical Tsunami Database (doi. org/10.7289/V5PN93H7), about 50 tsunamis with wave heights ranging from $1 \mathrm{~cm}(0.4$ in) to $2.7 \mathrm{~m}$
(8.9 ft) have reached Adak in recorded history. The same database lists ten tsunamis that reached Atka, with wave heights ranging from $6 \mathrm{~cm}$ (2.4 in) to $9.14 \mathrm{~m}(30 \mathrm{ft})$. Table 1 summarizes tsunamis greater than $15 \mathrm{~cm}(0.5 \mathrm{ft})$ at Adak and Atka.

Table 1. Tsunami effects at Adak and Atka: Data from the National Centers for Environmental Information Global Historical Tsunami Database (www.ngdc.noaa.gov/hazard/tsu_db.shtml) and comments from Lander (1996).

\begin{tabular}{|c|c|c|c|c|}
\hline Date & $\begin{array}{l}\text { Magnitude } \\
\qquad\left(\mathrm{M}_{\mathrm{w}}\right)\end{array}$ & Origin & $\begin{array}{l}\text { Maximum } \\
\text { water } \\
\text { height in } \\
\text { meters ( } \mathrm{ft} \text { ) }\end{array}$ & Comments \\
\hline \multicolumn{5}{|c|}{ Adak } \\
\hline 04/01/1946 & 8.6 & $\begin{array}{l}\text { Unimak } \\
\text { Island, } \\
\text { Alaska }\end{array}$ & $0.23(0.8)$ & - \\
\hline $11 / 04 / 1952$ & 9.0 & $\begin{array}{l}\text { Kamchatka } \\
\text { Peninsula }\end{array}$ & $1.1(3.6)$ & $\begin{array}{l}\text { The waves slightly overflowed the banks of } \\
\text { the harbor and flooded low-lying areas in } \\
\text { Sweeper Cove. }\end{array}$ \\
\hline 03/09/1957 & 8.6 & $\begin{array}{l}\text { Aleutian } \\
\text { Islands }\end{array}$ & $3.8(12.5)$ & $\begin{array}{l}\text { Tsunami caused severe damage. All } \\
\text { structures at the fuel and oil dock washed } \\
\text { away up to } 4 \mathrm{~m} \text { elevation; oil pipelines } \\
\text { damaged. }\end{array}$ \\
\hline $05 / 22 / 1960$ & 9.5 & Chile & $1.1(3.6)$ & - \\
\hline $03 / 28 / 1964$ & 9.2 & $\begin{array}{l}\text { Gulf of } \\
\text { Alaska }\end{array}$ & $0.27(0.9)$ & - \\
\hline 02/04/1965 & 8.7 & Rat Islands & $0.46(1.5)$ & Sea level fell 1.2 feet in 15 minutes. \\
\hline $11 / 22 / 1969$ & 7.7 & $\begin{array}{l}\text { Kamchatka } \\
\text { Peninsula }\end{array}$ & $0.3(1.0)$ & - \\
\hline 05/07/1986 & 8.0 & $\begin{array}{l}\text { Andreanof } \\
\text { Islands }\end{array}$ & $0.88(2.9)$ & - \\
\hline 06/10/1996 & 7.9 & $\begin{array}{l}\text { Andreanof } \\
\text { Islands }\end{array}$ & $0.51(1.7)$ & - \\
\hline $11 / 15 / 2006$ & 8.3 & Kuril Islands & $0.2(0.7)$ & - \\
\hline $02 / 27 / 2010$ & 8.8 & Chile & $0.38(1.2)$ & - \\
\hline 03/11/2011 & 9.0 & $\begin{array}{l}\text { Honshu, } \\
\text { Japan }\end{array}$ & $1.1(3.6)$ & - \\
\hline \multicolumn{5}{|c|}{ Atka } \\
\hline 03/09/1957 & 8.6 & Alaska & $9.14(30.0)$ & $\begin{array}{l}\text { Tsunami washed the skiffs up the creek and } \\
\text { washed away all of the boathouses and also } \\
\text { the oil supply of the village. Big pilings were } \\
\text { washed to a height of about } 10 \mathrm{~m} \text {. }\end{array}$ \\
\hline 02/27/2010 & 8.8 & Chile & $0.42(1.4)$ & - \\
\hline
\end{tabular}


Although the primary tsunami danger to Adak and Atka is from the Alaska-Aleutian megathrust, they are also vulnerable to tsunamis generated by circum-Pacific earthquakes. Tsunamis from earthquakes in Japan, Chile, and Kamchatka have been recorded in both Adak and Atka (table 1). During the 2011 Tohoku tsunami, Adak was the only town in Alaska with significant effects. According to the Adak harbormaster, sea levels rose and fell at the harbor entrance, similar to a fast-moving tide at -15 minute intervals. Vessels could not enter or leave the harbor and a number of vessels waited out in deeper waters. There was minor damage at the small boat harbor when a floating dock was lifted over the top of its piling. This demonstrates that even distant earthquakes can produce significant tsunamis in Alaska and should not be dismissed from consideration.

\section{METHODOLOGY AND DATA Grid Development and Data Sources}

We use a series of nested computational grids to calculate high-resolution tsunami inundation for each community. The bathymetry and topography in level 0-3 grids are based on digital elevation models (DEMs) developed at the National Centers for Environmental Information (NCEI), a part of the National Oceanic \& Atmospheric Administration (NOAA) (table 2; fig. 3). The coarsest grid, with 2-arc-minute resolution (approximately $2 \mathrm{~km}$ [ $1.2 \mathrm{mi}])$, spans the central and northern Pacific Ocean and is extracted from NCEI's "ETOPO2" dataset. We used three intermediate grids, the 24-, 8-, and 3-arc-second DEMs (table 2; fig. 3), for which data sources and methodology are described

Table 2. Nested grids used to compute propagation of tsunami waves from the Pacific to Adak and Atka. The level 4 grid is used to compute inundation. Note that the grid resolution is not uniform: the first dimension is the longitudinal grid resolution and the second is the latitudinal resolution. Measurements also vary across each grid and are given for a reference location near Atka to illustrate relative grid resolution

\begin{tabular}{|c|c|c|c|c|}
\hline \multirow[b]{2}{*}{ Grid name } & \multicolumn{2}{|c|}{ Resolution } & \multirow{2}{*}{$\begin{array}{l}\text { East-West } \\
\text { boundaries }\end{array}$} & \multirow{2}{*}{$\begin{array}{c}\text { North-South } \\
\text { boundaries }\end{array}$} \\
\hline & $\begin{array}{c}\text { Arc- } \\
\text { seconds }\end{array}$ & $\begin{array}{c}\text { Meters (feet), } \\
\text { near Atka }\end{array}$ & & \\
\hline Level 0, Northern Pacific & $120 \times 120$ & $\begin{array}{l}\approx 2,276 \times 3,704 \\
(\approx 7,467 \times 12,152)\end{array}$ & $\begin{array}{l}120^{\circ} 00^{\prime} \mathrm{E}- \\
100^{\circ} 00^{\prime} \mathrm{W}\end{array}$ & $\begin{array}{l}10^{\circ} 00^{\prime} \mathrm{N}- \\
65^{\circ} 00^{\prime} \mathrm{N}\end{array}$ \\
\hline Level 1, Western Aleutians & $40 \times 40$ & $\begin{array}{l}\approx 758 \times 1,233 \\
(\approx 2,487 \times 4,045)\end{array}$ & $\begin{array}{l}172^{\circ} 00^{\prime} \mathrm{E}- \\
173^{\circ} 13^{\prime} \mathrm{W}\end{array}$ & $\begin{array}{l}48^{\circ} 44^{\prime} \mathrm{N}- \\
55^{\circ} 29^{\prime} \mathrm{N}\end{array}$ \\
\hline $\begin{array}{l}\text { Level 2, Coarse resolution, } \\
\text { Adak-Atka }\end{array}$ & $13 \times 13$ & $\begin{array}{l}\approx 253 \times 411 \\
(\approx 830 \times 1,348)\end{array}$ & $\begin{array}{l}180^{\circ} 27^{\prime} 27^{\prime \prime} \mathrm{W}- \\
173^{\circ} 42^{\prime} 27^{\prime \prime} \mathrm{W}\end{array}$ & $\begin{array}{l}51^{\circ} 09^{\prime} 27^{\prime \prime} \mathrm{N}- \\
52^{\circ} 47^{\prime} 13^{\prime \prime} \mathrm{N}\end{array}$ \\
\hline $\begin{array}{l}\text { Level 3, Fine resolution, } \\
\text { Adak }\end{array}$ & $4 \times 4$ & $\begin{array}{l}\approx 84 \times 137 \\
(\approx 276 \times 449)\end{array}$ & $\begin{array}{l}179^{\circ} 18^{\prime} 18^{\prime \prime} \mathrm{W}- \\
176^{\circ} 35^{\prime} 56^{\prime \prime} \mathrm{W}\end{array}$ & $\begin{array}{l}51^{\circ} 32^{\prime} 56^{\prime \prime} \mathrm{N}- \\
52^{\circ} 11^{\prime} 31^{\prime \prime} \mathrm{N}\end{array}$ \\
\hline $\begin{array}{l}\text { Level 3, Fine resolution, } \\
\text { Atka }\end{array}$ & $4 \times 4$ & $\begin{array}{l}\approx 84 \times 137 \\
(\approx 276 \times 449)\end{array}$ & $\begin{array}{l}176^{\circ} 23^{\prime} 51^{\prime \prime} \mathrm{W}- \\
173^{\circ} 51^{\prime} 16^{\prime \prime} \mathrm{W}\end{array}$ & $\begin{array}{l}51^{\circ} 46^{\prime} 56^{\prime \prime} \mathrm{N}- \\
52^{\circ} 29^{\prime} 31^{\prime \prime} \mathrm{N}\end{array}$ \\
\hline $\begin{array}{l}\text { Level 4, High resolution, } \\
\text { Adak }\end{array}$ & $1.5 \times 1$ & $\begin{array}{l}\approx 28 \times 27 \\
(\approx 92 \times 88)\end{array}$ & $\begin{array}{l}177^{\circ} 42^{\prime} 19^{\prime \prime} \mathrm{W}- \\
177^{\circ} 30^{\prime} 34^{\prime \prime} \mathrm{W}\end{array}$ & $\begin{array}{l}51^{\circ} 49^{\prime} 43^{\prime \prime} \mathrm{N}- \\
51^{\circ} 58^{\prime} 04^{\prime \prime} \mathrm{N}\end{array}$ \\
\hline $\begin{array}{l}\text { Level 4, High resolution, } \\
\text { Atka }\end{array}$ & $1.5 \times 1$ & $\begin{array}{l}\approx 28 \times 27 \\
(\approx 92 \times 88)\end{array}$ & $\begin{array}{l}175^{\circ} 16^{\prime} 28^{\prime \prime} \mathrm{W}- \\
175^{\circ} 01^{\prime} 10^{\prime \prime} \mathrm{W}\end{array}$ & $\begin{array}{l}52^{\circ} 04^{\prime} 14^{\prime \prime} N- \\
52^{\circ} 17^{\prime} 42^{\prime \prime} N\end{array}$ \\
\hline
\end{tabular}




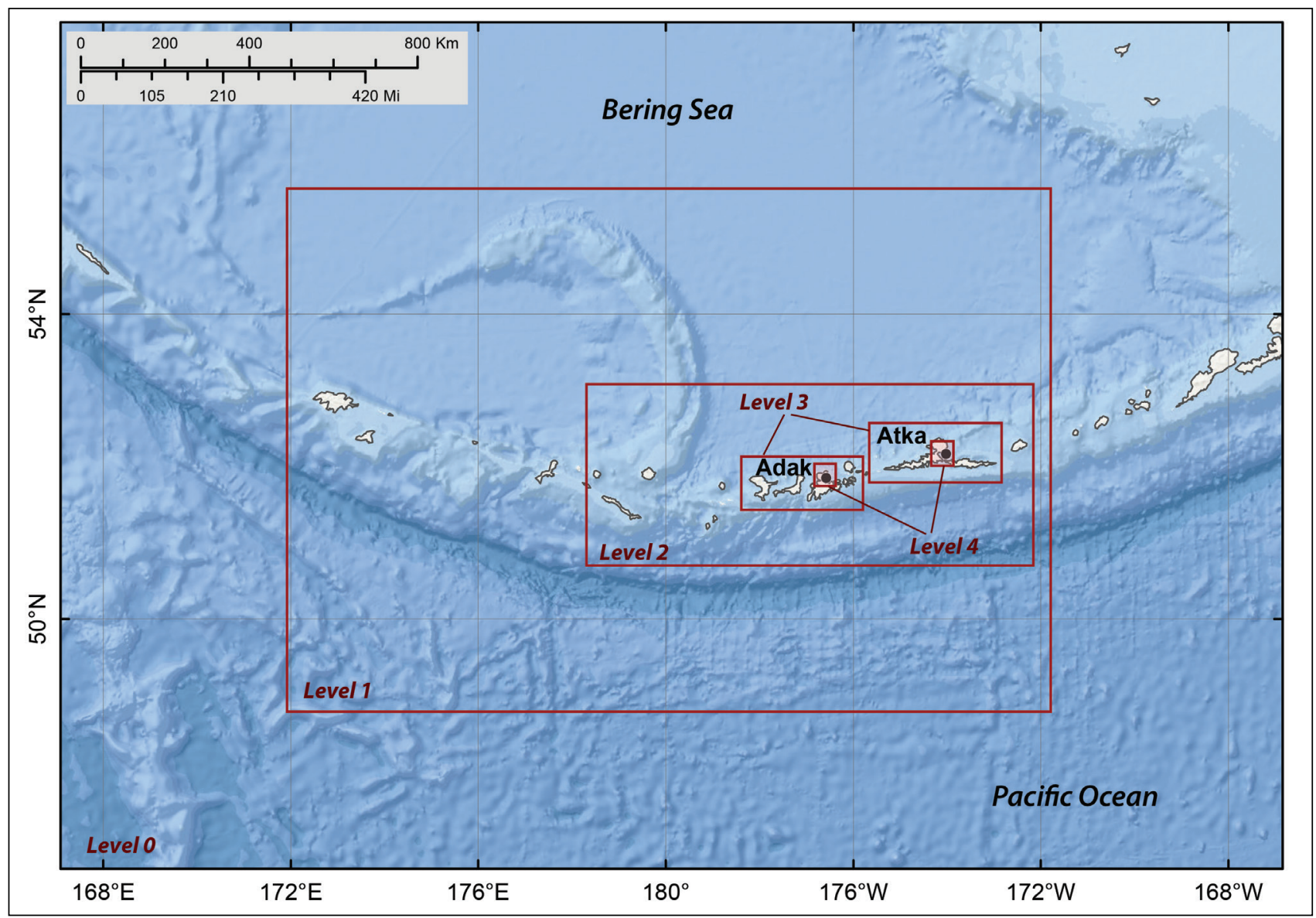

Figure 3. Nesting of the levels 0-4 bathymetry/topography grids for numerical modeling of tsunami propagation and runup in the Andrean of Islands area. Each embedded grid is outlined by a red rectangle.

in detail by Lim and others (2011), Carignan and others (2009), and Friday and others (2011). The areas covered by the highest-resolution grids for Adak and Atka, the 3-arc-second "level 4 grids," are shown in figure 3 . The high-resolution grids reflect $28 \times 27 \mathrm{~m}(92 \times 88 \mathrm{ft})$ cells, which satisfy the National Tsunami Hazard Mitigation Program (NTHMP) mapping and modeling committee minimum recommended requirements for computation of tsunami inundation (2010).

The level 4 DEMs are based on the DCRA elevation dataset. To minimize the vertical error resulting from conversion of the DCRA datum to the Mean Higher High Water (MHHW) datum, we augment our topographic dataset with elevations collected by a real-time kinematic (RTK) survey-grade Leica 500 Global Positioning System (GPS) (0.03-0.05 m [1-2 in] precision). Because there are no GPS monuments, we set up GPS base stations in both Adak and Atka. Both GPS surveys were tied to the water level measured with respect to the MHHW datum at local NOAA tide stations. The locations of GPS measurements in Adak and Atka are shown in figures 4 and 5, respectively, and a comparison of the GPS-estimated and NOAA-observed tide dynamics at Adak is shown in figure 6. The few anomalies are due to water level measurements made at unprotected locations along the coast where ocean waves made it difficult to determine the precise water level.

We checked the accuracy of GPS data converted to the MHHW level by estimating the height of the tidal station disk "NO 18 1957" in Adak (yellow triangle, fig. 4). According to the NOAA National Ocean Service (tidesandcurrents. noaa.gov), the disk is $4.74 \mathrm{~m}(15.56 \mathrm{ft})$ above 


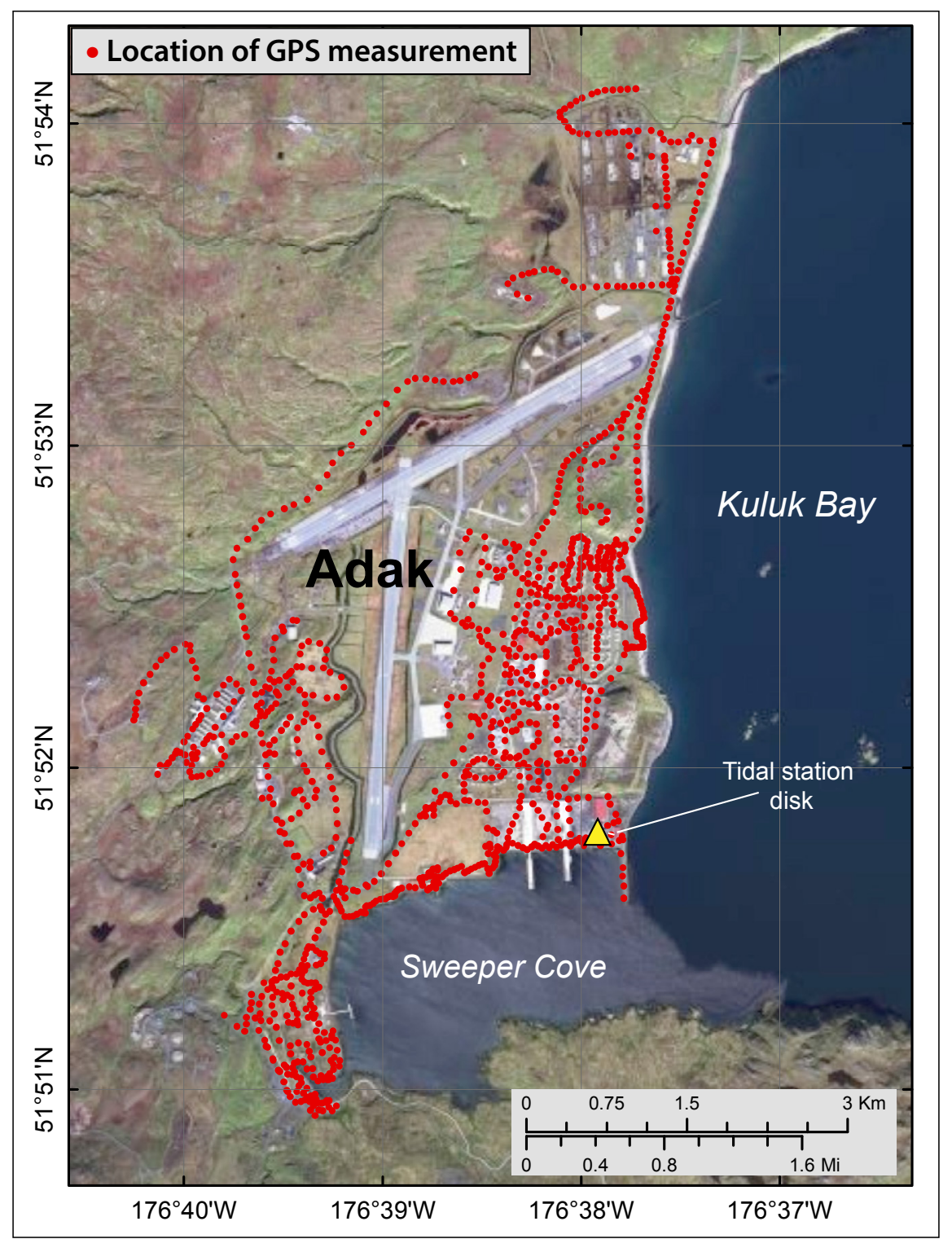

Figure 4. Locations of (real-time kinetic) RTK GPS measurements ( $n=1170$ ) in Adak. The yellow triangle indicates location of the tidal station disk NO 181957.

MHW and $4.67 \mathrm{~m}(15.31 \mathrm{ft})$ above MHHW. After measuring the height of this disk during the GPS survey and adjusting to the MHHW datum, we determine that the disk is $4.68 \mathrm{~m}(15.35 \mathrm{ft})$ above MHHW. The difference-less than $0.03 \mathrm{~m}$ $(0.1 \mathrm{ft})$ between the NOAA stamping and our estimate-demonstrates that our conversion provides sub-decimeter accuracy. Finally, the collected GPS measurements have horizontal accuracy (datum WGS84) of 3-5 m (10-16 ft) (Leica Geosystems AG, 2002). The base station was not horizontally controlled by the benchmarks. The converted GPS survey was provided to NCEI and incorporated into the DEM development process.

\section{NUMERICAL MODEL OF TSUNAMI PROPAGATION AND RUNUP}

To estimate tsunami propagation and runup we used a numerical model successfully employed in multiple previous studies (see dggs.alaska. gov/pubs/tsunami). This model has been verified through a set of analytical benchmarks and extensively tested against laboratory and field data (Nicolsky and others, 2011; Nicolsky, 2012). The 


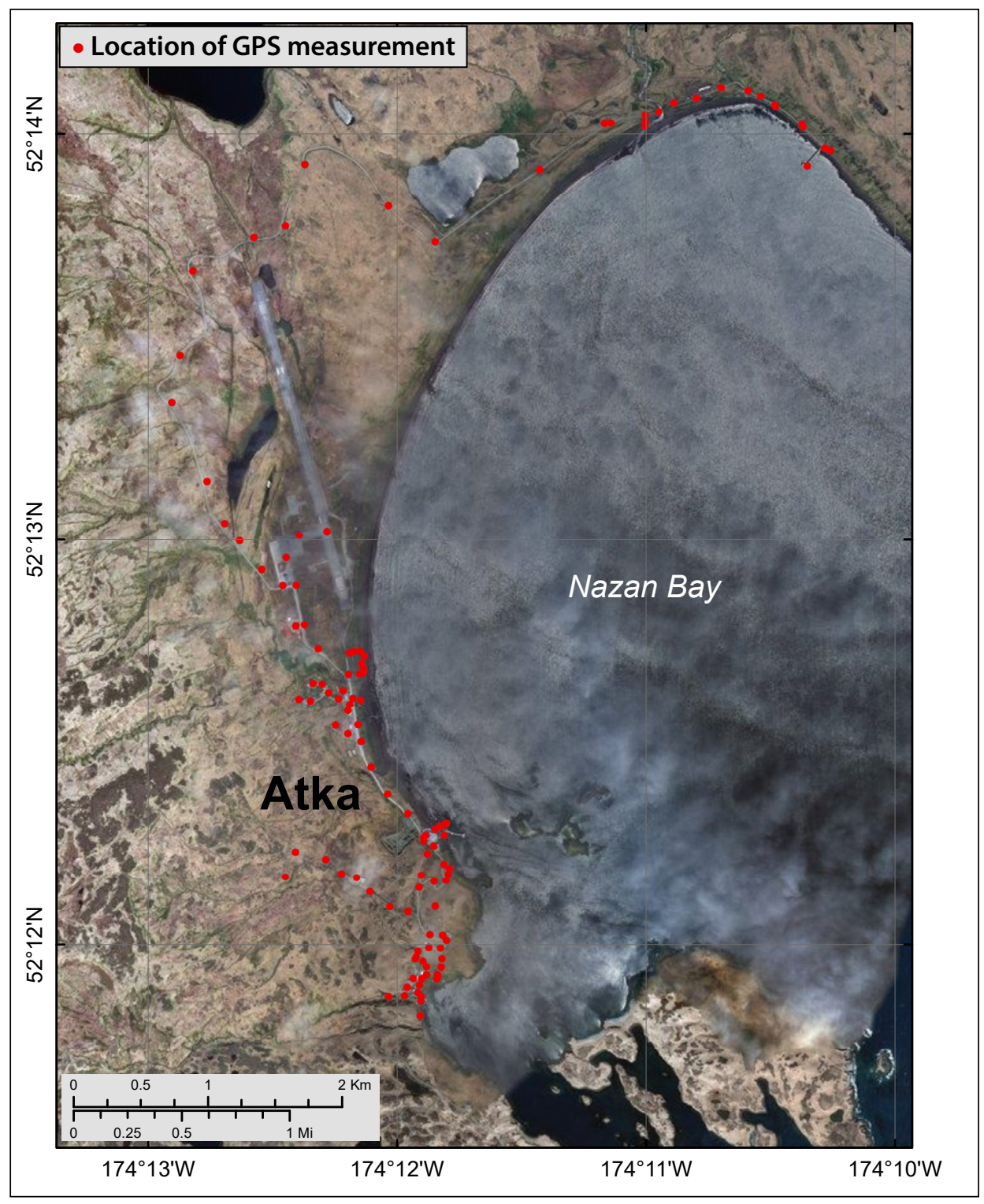

Figure 5. Locations of RTK GPS measurements $(n=118)$ in Atka.

model uses an ocean surface displacement (due to an earthquake-generated seafloor deformation) as an initial condition and solves nonlinear shallow-water equations using a finite-difference method on a staggered grid. Because the numerical model does not dynamically simulate interaction of tides and tsunami waves, we use a safe approach and assume that the tsunami arrives at high tide. All simulations are conducted using bathymetric/topographic data corresponding to MHHW level in the communities. Previous studies demonstrated that the extent of the simulated tsunami inundation is sensitive to parameterization of the ocean-bottom drag coef- ficient, that is, the surface roughness coefficient $\mu$ in the Manning formula (Nicolsky and others, 2011). We use a value of surface roughness $\mu=0.02$ $\mathrm{m}^{1 / 3} / \mathrm{s}\left(0.03 \mathrm{ft}^{1 / 3} / \mathrm{s}\right)$ that corresponds to straight and uniform Earth surface (www.fsl.orst.edu/geowater/ FX3/help/8_Hydraulic_Reference/Mannings_n_ Tables.htm).

\section{Validation of the Model with the March 11, 2011, Tohoku Tsunami}

To assess accuracy of the grid nesting around communities, we compared modeled waves of the Tohoku tsunami of March 11, 2011, with 


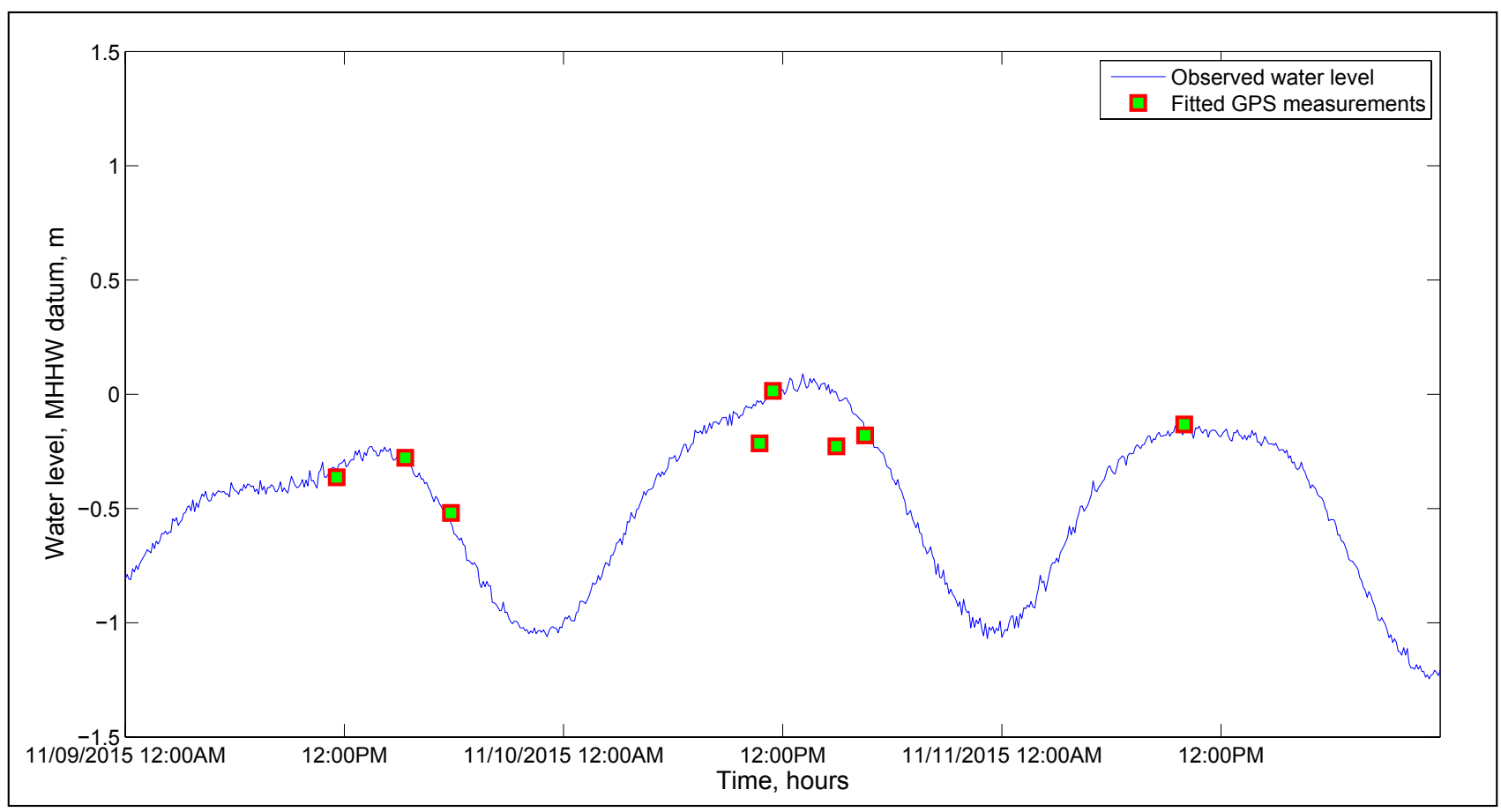

Figure 6. Observed water-level dynamics in Adak and GPS measurements of water level in the MHHW datum.

observed waves for the Tohoku tsunami at the Adak tide station (point 1 in fig. A1; e.g., Nicolsky and others, 2015). We used the finite fault inversion model phase III from Shao and others (2011) to replicate vertical coseismic deformation of the Tohoku earthquake (fig. 7). The Tohoku tsunami produced a $1.1 \mathrm{~m}(3.6 \mathrm{ft})$ maximum wave in Adak (NCEI/WDS Global Historical Tsunami Database), whereas our simulation results in a $1.17 \mathrm{~m}$ $(3.84 \mathrm{ft})$ wave (table 1$)$.

Tang and others (2012) demonstrated that, except for the stations close to the 2011 Tohoku earthquake source area, numerically modeled tsunamis travel faster and reach shores faster than actual tsunami waves. Tsunami travel in natural, open systems involves many complexities (due to elasticity of the solid earth, seawater compressibility, and variations of gravitational potential) not included in a numerical model, and therefore a modeled tsunami may arrive up to 15 minutes sooner than the actual, observed tsunami (Watada and others, 2014). Like Tang and others (2012), our computed wave arrived 6 minutes faster than the observed waves arrived at Adak in 2011.
After adjusting for this 6-minute discrepancy, our modeled waveform reproduces well the phase of actual Tohoku tsunami waves for up to three hours after the arrival of the first wave. The largest wave occurred 12 hours after the earthquake and was caused either by local effects, such as resonant wave amplification in Sweeper Cove, or redirection of energy flux due to interaction of the tsunami with seafloor topography (Tang and others, 2012). We infer that our model sufficiently replicates the onset and first few hours of the Tohoku tsunami, but does not accurately represent reflected and trapped waves more than a few hours after the first wave arrival. The level 3 DEMs surrounding the Andreanof Islands are too coarse to properly model cumulative wave interaction and dispersion effects over longer periods of time.

\section{TECTONIC TSUNAMI SOURCES Sensitivity Study}

A comprehensive understanding of subduction zone behavior near the Andreanof Islands is hindered by the lack of geodetic data close to the Aleutian trench. For instance, locating the up-dip 


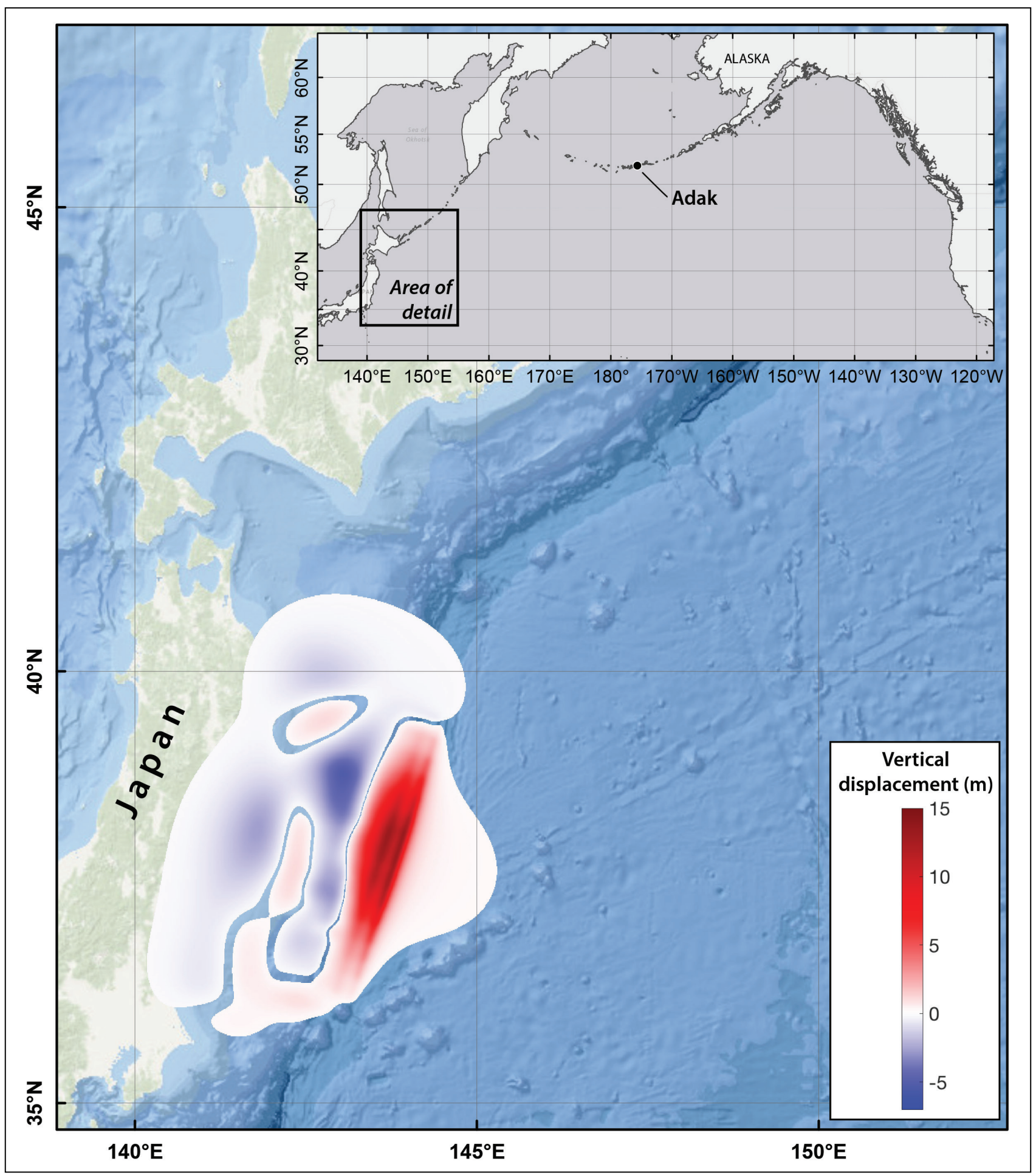

Figure 7. Map of vertical deformations of the ocean floor and adjacent coastal region corresponding to the March 11, 2011, Tohoku earthquake, based on a finite fault model by Shao and others (2011). Warm colors indicate uplift; blue indicates subsidence. Inset shows the location of the map with respect to the Adak tide gauge (black dot). 


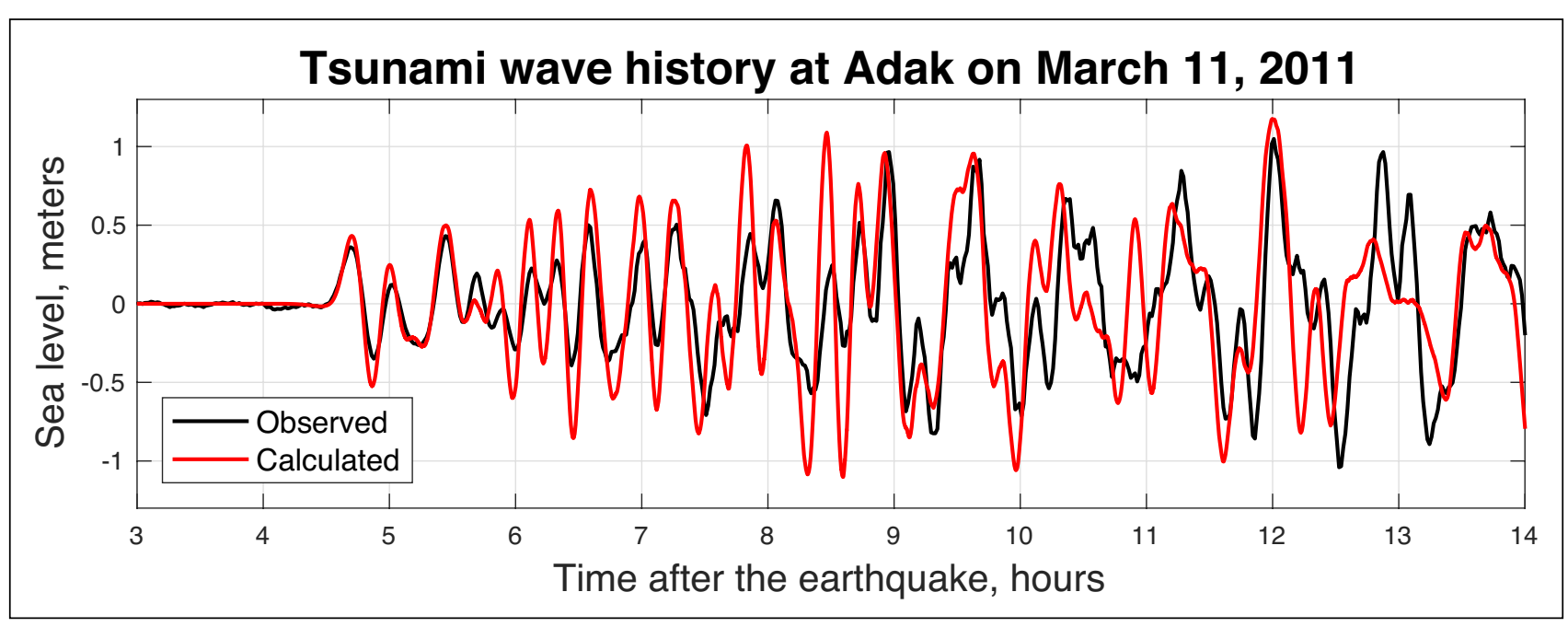

Figure 8. Observed and simulated water-level dynamics at the Adak tide station during the 14-hour period following the March 11, 2011, Tohoku earthquake.

limit of the locked zone of the plate interface is difficult because there are no necessary seafloor GPS/acoustic measurements with which to make that determination. However, recent studies comparing the Alaska and Tohoku tectonic margins suggest that there are several similarities between the two areas and that a hypothetical rupture could propagate to shallow depths on the Alaska-Aleutian megathrust in a manner similar to the $\mathrm{M}_{\mathrm{w}} 9.0$ Tohoku earthquake (Kirby and others, 2013). Earthquakes from this upper portion of the plate interface tend to cause greater perturbations to the seafloor and, as a result, have the potential to generate substantial tsunamis and cause accentuated tectonic uplift and subsidence. Therefore, we include earthquakes that rupture the shallow locked zone in our scenarios. Additionally, we conduct a sensitivity study to determine precisely what effect the down-dip location of a rupture has on tectonic subsidence, uplift, and resulting tsunami waves. We consider these results when developing maximum credible earthquake source scenarios.

We use a model of the Alaska-Aleutian plate interface referred to as Slab 1.0 from Hayes and others (2012; fig. 9). The plate interface is discretized into a mesh of rectangles ranging from 3-6 $\mathrm{km}(1.9-3.7 \mathrm{mi})$ in the along-strike (-east-west) direction. The upper and lower edges of each rect- angle are spaced at $1 \mathrm{~km}(0.6 \mathrm{mi})$ depth contours. We model potential earthquake scenarios by first prescribing a general pattern of earthquake slip, limiting the maximum size of the earthquake by total energy released (i.e., seismic moment), and then computing the slip at the center of each subfault. Earthquake displacements on each subfault are used to compute the coseismic seafloor deformation (e.g., Okada, 1985).

The depth of a megathrust rupture controls the amount and distribution of regional subsidence and uplift, and therefore the resulting tsunami inundation and permanent flooding characteristics. We developed five different slip scenarios (cases A-E) for $M_{W} 8.0$ earthquakes near the Andreanof Islands and calculate regional vertical deformations associated with each (figs. 10 and 11 for Adak and Atka, respectively). To keep the seismic moment constant for all scenarios, we vary the total amount of co-seismic slip according to the overall rupture area. For example, the width of the rupture area is defined in the down-dip direction. Because the subduction interface steepens with depth, deeper earthquakes have smaller rupture widths but greater amounts of total slip. The relative slip distribution for all five cases is identical: uniform in the along-strike direction, with tapered ends and a symmetrical bell-curve distribution in the downdip direction. 


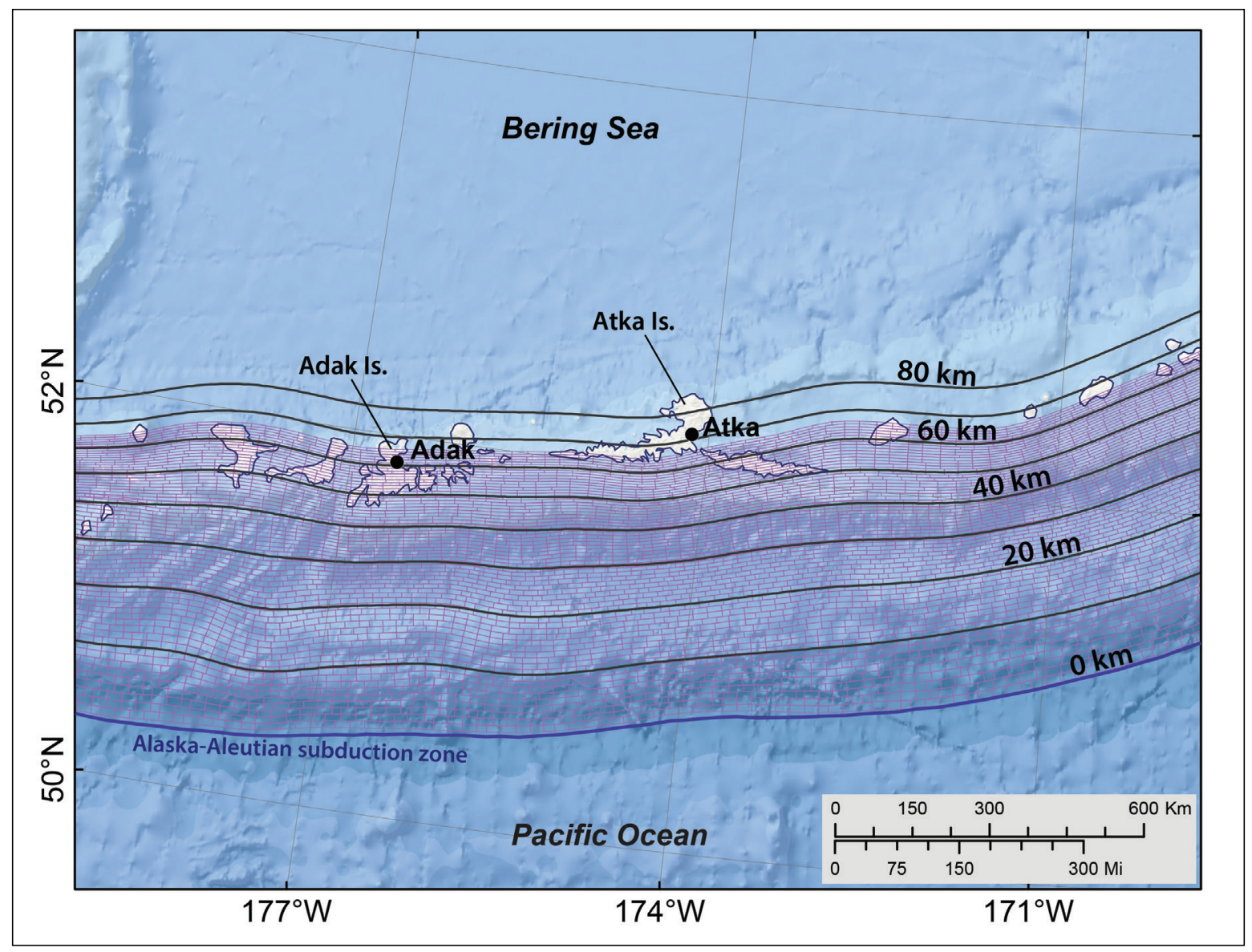

Figure 9. Mosaic of the discretized plate interface in the area of Andreanof Islands used for construction of hypothetical ruptures. Black lines are depth contours of the subducting plate interface; black numbers indicate depth in kilometers from the ocean floor to the interface. The approximate location of the trench is shown by the solid blue line.

For each case A-E we calculated tectonic subsidence/uplift and water dynamics close to Adak and Atka (fig. 12). Overall, the cases B, C, and $\mathrm{D}$ produced larger waves in both communities as compared to cases $\mathrm{A}$ and $\mathrm{E}$. The time series indicate that the rupture at $30 \mathrm{~km}(18.6 \mathrm{mi})$ depth (case C) resulted in the highest wave amplitudes in both Adak and Atka because this scenario corresponds to the greatest subsidence during the earthquake: $96 \mathrm{~cm}$ $(3.1 \mathrm{ft})$ in Adak and $1 \mathrm{~m}(3.3 \mathrm{ft})$ in Atka. The waves generated by the shallow ruptures of cases $\mathrm{A}$ and $\mathrm{B}$ arrived later and were smaller than case $\mathrm{C}$. The deep rupture represented by case $\mathrm{E}$ produced coseismic uplift in Adak. As a result, land and the nearby seabed rose with respect to pre-earthquake sea level and the arriving waves effectively had smaller amplitudes.
On the basis of these results, we develop hypothetical ruptures with maximum slip in the 20-40 $\mathrm{km}$ (12.4-25 mi) depth range (cases B-D) and the capability to generate the highest amplitude waves in the Andreanof Islands. As in Nicolsky and others (2016), we develop maximum credible scenarios by assuming slip of up to $35 \mathrm{~m}$ (115 ft) in the deep and intermediate sections of the Alaska-Aleutian megathrust, and up to $55 \mathrm{~m}(180 \mathrm{ft})$ in the shallow sections of the megathrust. These slip distributions are consistent with earthquake source scenarios used by other tsunami modeling studies (for example, Butler, 2014; USGS SAFRR scenario, www2.usgs.gov/natural_hazards/safrr/projects/ tsunamiscenario.asp). 

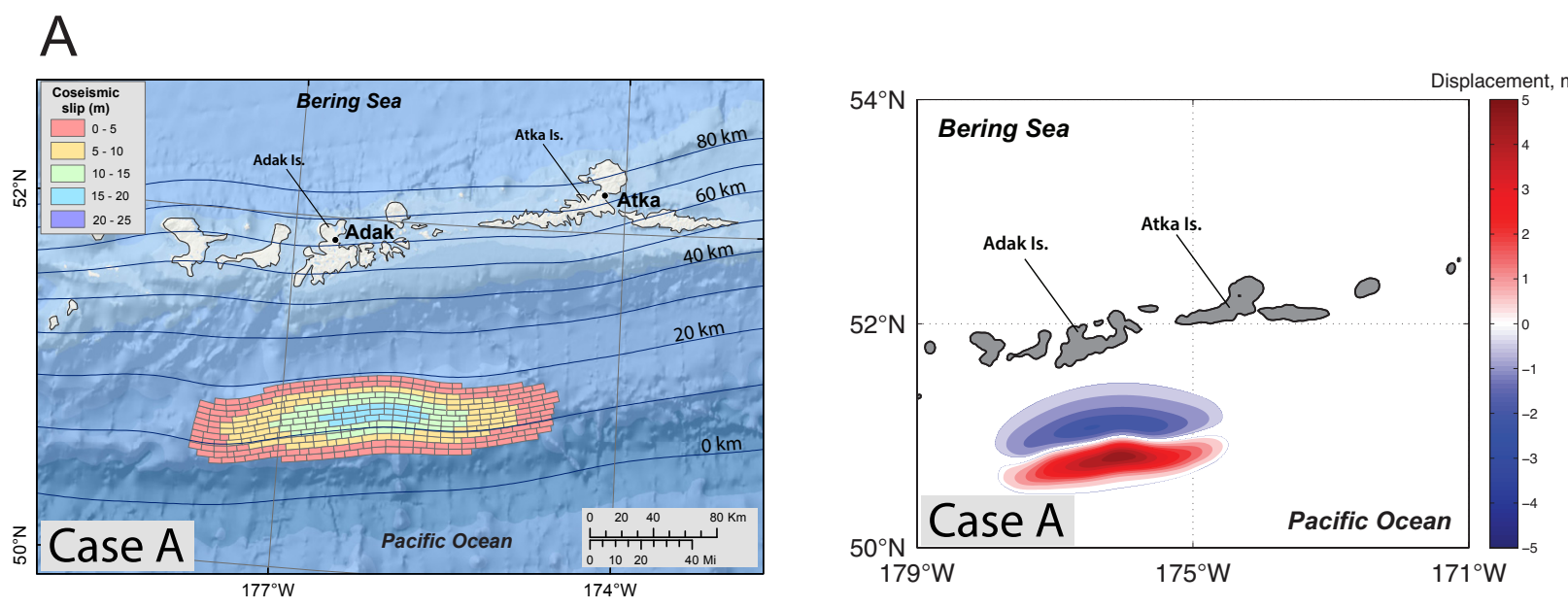

B
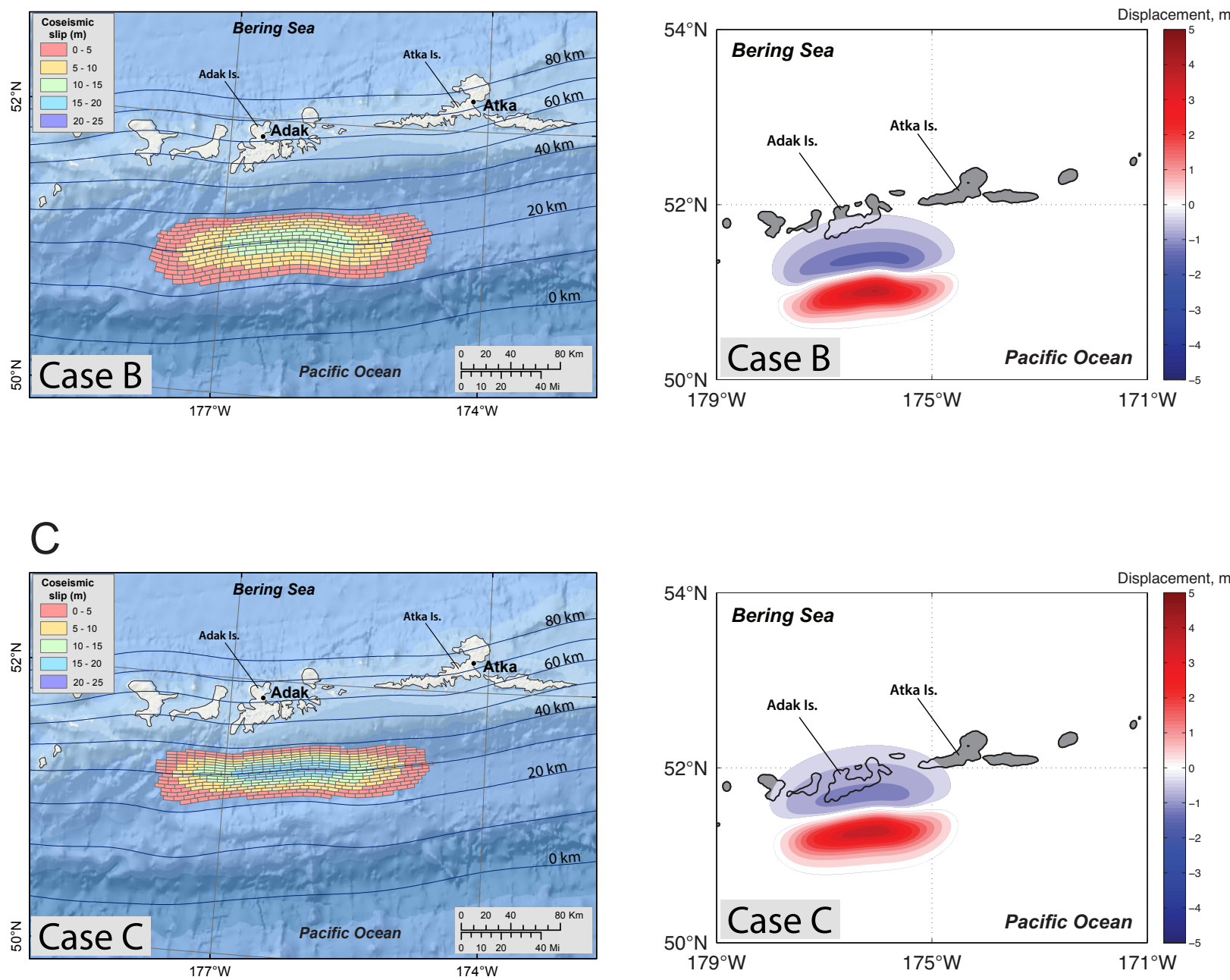

Figure 10A-C. Hypothetical slip distributions (left column) and vertical coseismic deformations (right column) along the plate interface for cases $A-C$, modeling $M_{W} 8.0$ ruptures offshore Adak. The hypothetical ruptures are offset by $10 \mathrm{~km}$ $(6.2 \mathrm{mi})$ in the downdip direction: cases $A-C$ correspond to ruptures at $10 \mathrm{~km}(6.2 \mathrm{mi}), 20 \mathrm{~km}(12.4 \mathrm{mi}), 30 \mathrm{~km}(18.6 \mathrm{mi})$, depth, respectively. The slip location varies in the downdip direction of the plate interface while preserving the same patch configuration. Black lines are depth contours of the subduction interface, in meters. Blue areas are associated with coseismic surface subsidence; areas of uplift are shown in red. 


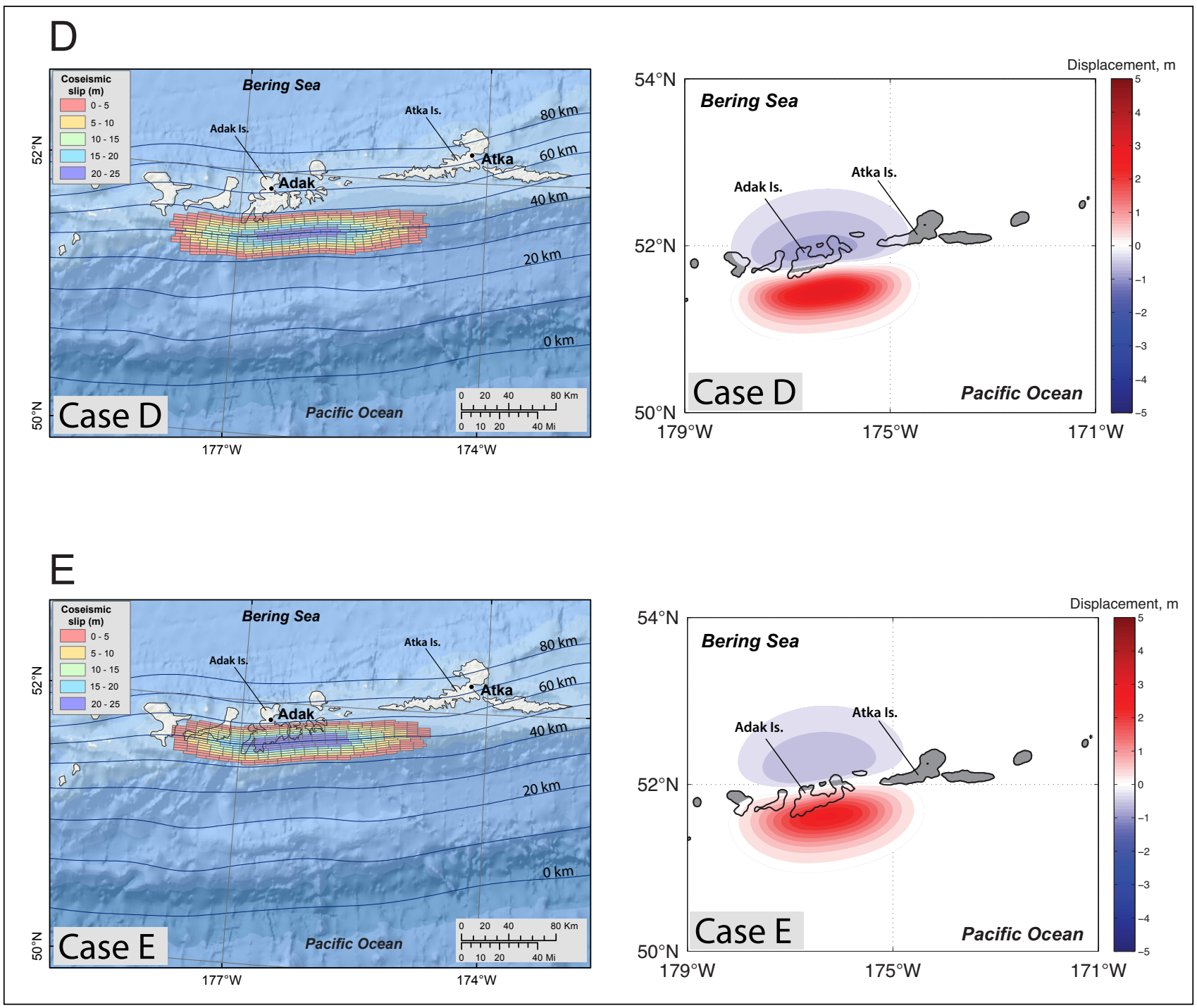

Figure 10D, E. Hypothetical slip distributions (left column) and vertical coseismic deformations (right column) along the plate interface for cases $D$ and $E$, modeling $M_{W} 8.0$ ruptures offshore Adak. The hypothetical ruptures are offset by $10 \mathrm{~km}(6.2 \mathrm{mi})$ in the downdip direction: cases A-E correspond to ruptures at $40 \mathrm{~km}$ (25 mi), and $50 \mathrm{~km}$ (31 mi) depth, respectively. The slip location varies in the downdip direction of the plate interface while preserving the same patch configuration. Black lines are depth contours of the subduction interface, in meters. Blue areas are associated with coseismic surface subsidence; areas of uplift are shown in red.

\section{CONSIDERED TSUNAMI SCENARIOS}

We develop nine geologically plausible tsunamigenic earthquake scenarios that generate maximal credible tsunami inundation in Adak (fig. 13, table 3). For Atka, we transpose the same rupture patches slightly to the east in order to achieve maximal credible tsunami inundation there (fig. 14). In previous studies, we limited the coseismic slip to $18.5 \mathrm{~m}(60.6 \mathrm{ft})$ near the seafloor trench (Suleimani and others, 2005). Based on modeling results of the USGS SAFRR project and considering implications of the 2011 shallow-slip Tohoku rupture, we now suggest that the maximum slip near the seafloor trench could be as great as 50 $\mathrm{m}(160 \mathrm{ft})$. Also, for the sake of consistency with previous reports (e.g., Nicolsky and others, 2016, 2017; Suleimani and others, 2016), we consider two earthquakes (scenarios 6 and 7) with slip 


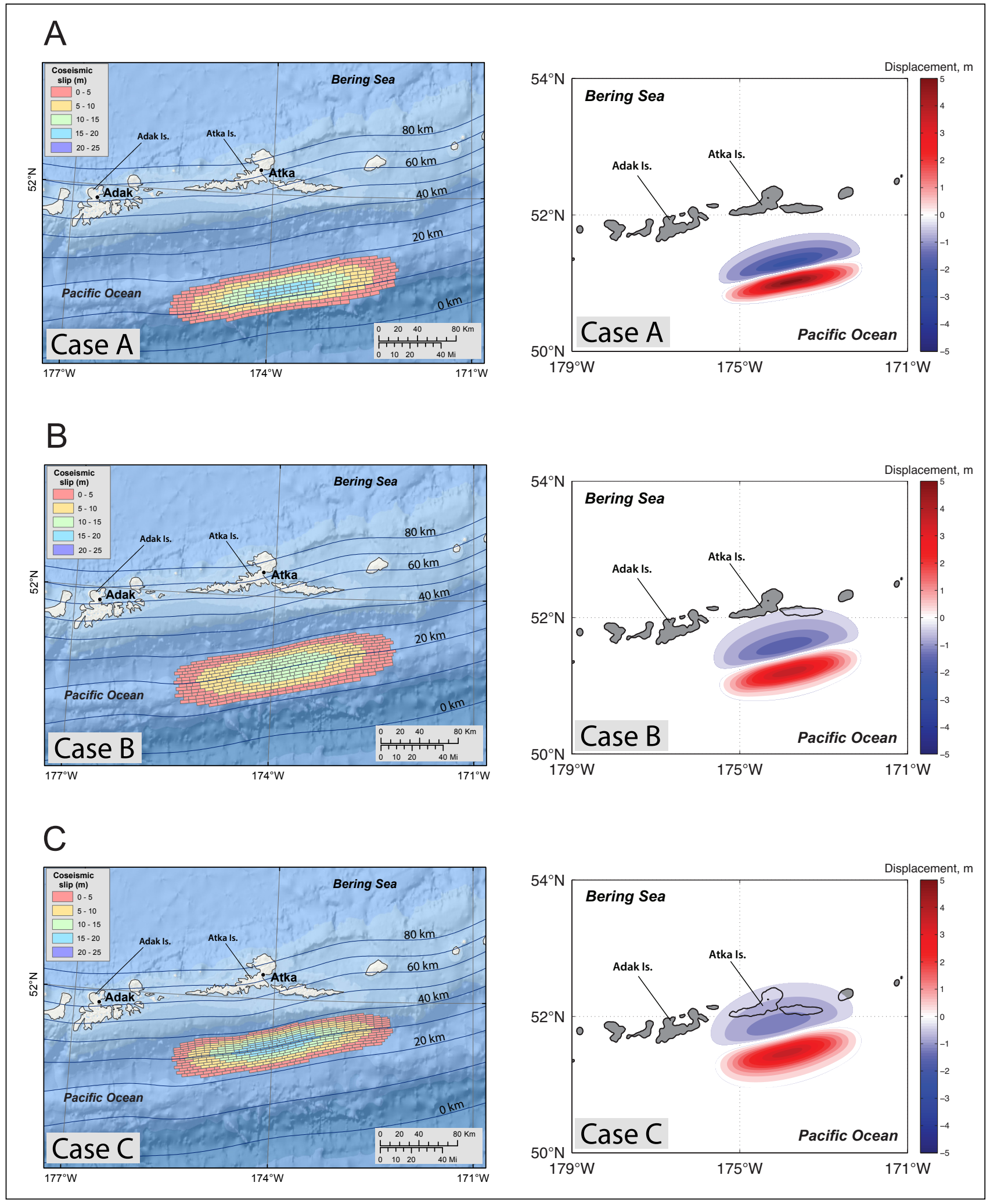

Figure 11A-C. Hypothetical slip distributions (left column) and coseismic deformations (right column) along the plate interface for cases $A-C$, modeling $M_{w} 8.0$ ruptures offshore Atka. The hypothetical ruptures are offset by $10 \mathrm{~km}(6.2$ $\mathrm{mi}$ ) in the downdip direction: cases $\mathrm{A}-\mathrm{C}$ correspond to ruptures at $10 \mathrm{~km}(6.2 \mathrm{mi}), 20 \mathrm{~km}(12.4 \mathrm{mi})$, and $30 \mathrm{~km}(18.6 \mathrm{mi})$ depth, respectively. The slip location varies in the downdip direction of the plate interface while preserving the same patch configuration. Black lines are depth contours of the subduction interface, in meters. Blue areas are associated with coseismic surface subsidence; areas of uplift are shown in red. 


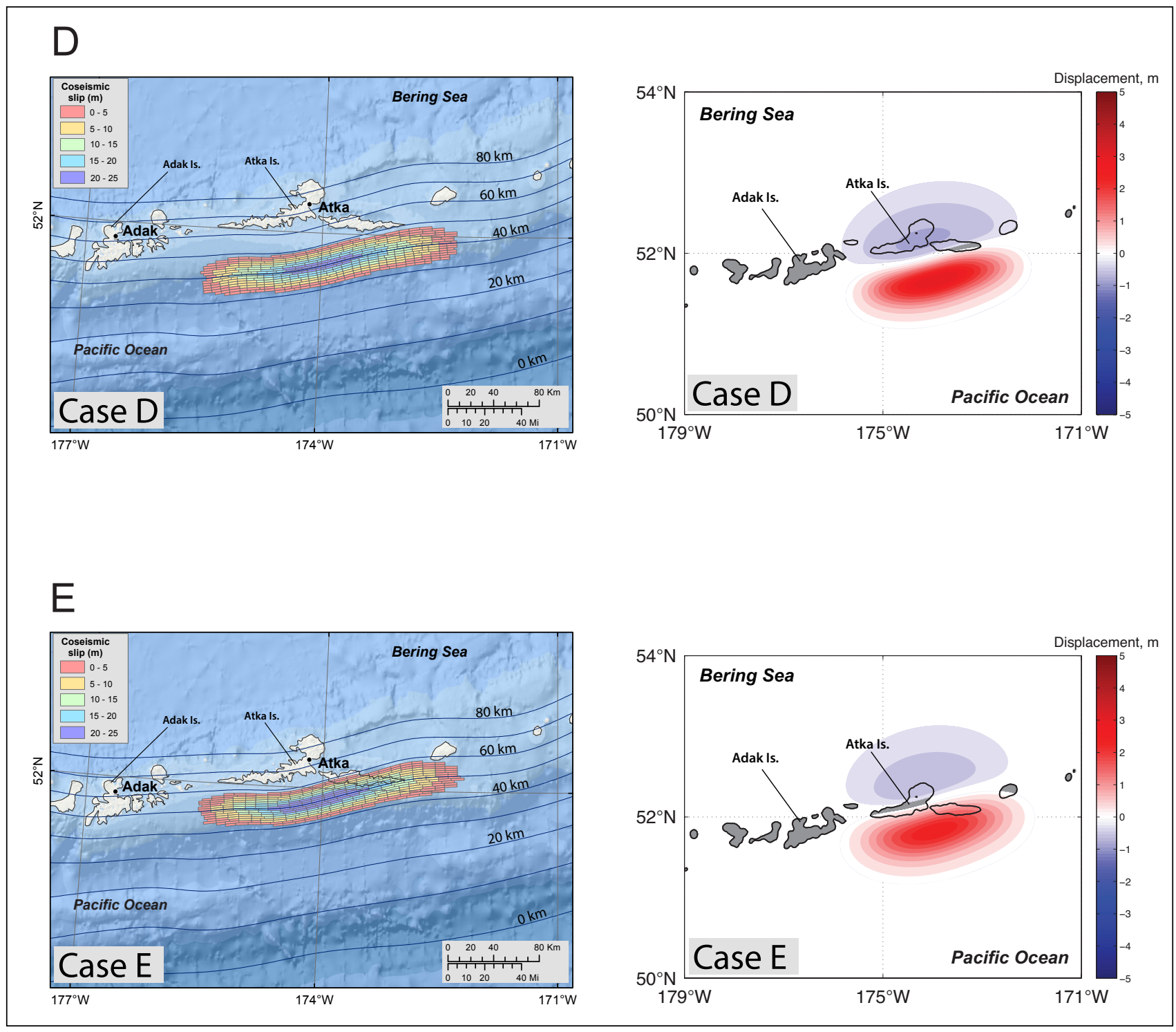

Figure 11D, E. Hypothetical slip distributions (left column) and coseismic deformations (right column) along the plate interface for cases $D$ and $E$, modeling $M_{W} 8.0$ ruptures offshore Atka. The hypothetical ruptures are offset by $10 \mathrm{~km}$ $(6.2 \mathrm{mi})$ in the downdip direction: cases D and E correspond to ruptures at $40 \mathrm{~km}(25 \mathrm{mi})$ and $50 \mathrm{~km}(31 \mathrm{mi})$ depth, respectively. The slip location varies in the downdip direction of the plate interface while preserving the same patch configuration. Black lines are depth contours of the subduction interface, in meters. Blue areas are associated with coseismic surface subsidence; areas of uplift are shown in red.

parameterization according to Butler and others (2014). Additionally, we include two sources from previous inundation mapping reports: the SAFRR tsunami scenario (Ross and Jones, 2013) as scenario 8 , and the rupture of the Cascadia subduction zone (Wang and others, 2003; Witter and others, 2011) as scenario 9 .

For each scenario, we simulate impacts in Adak and Atka. We do not account for the finite speed of rupture propagation along the fault or for effects from horizontal seafloor movement, and we assume the ocean-bottom displacements to be instantaneous. Table 3 describes each of the scenarios, which are grouped based on earthquake source parameters such as slip distribution and geographical location. The proposed slip distributions and vertical coseismic deformations for scenarios 1-7 are shown in figures 13-16. 


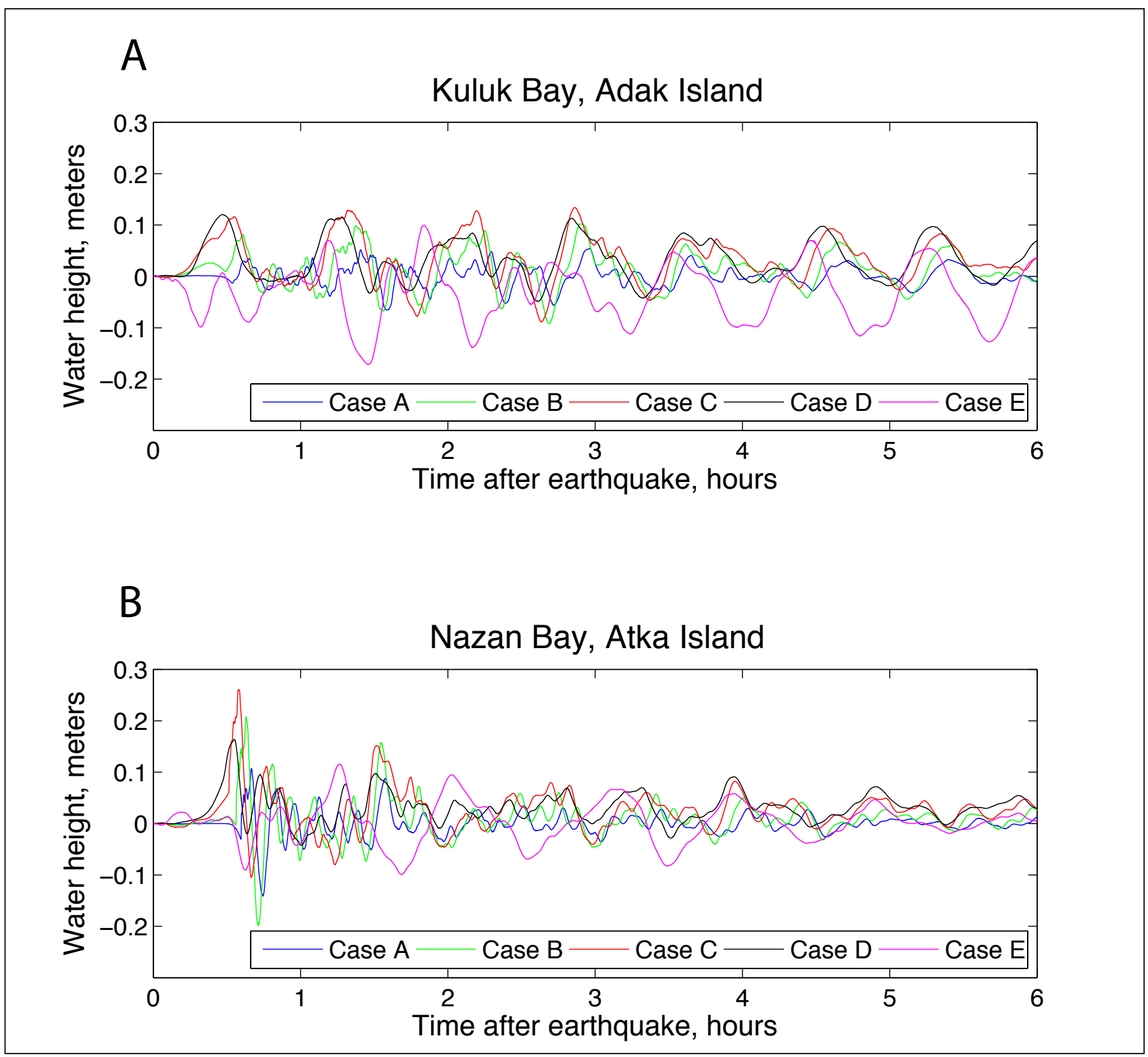

Figure 12. Modeled water-level dynamics for the vertical coseismic deformations shown in figures 10 and 11 . The location of the Adak time series is shown by point 1 in figure A1, and the location of the Atka time series is shown by point 1 in figure B1. 
Table 3. Hypothetical tectonic scenarios used to model tsunami runup in Adak and Atka. Al = Andreanof Islands.

\begin{tabular}{|c|c|c|c|c|c|c|c|}
\hline Group & \# & $M_{w}$ & Description & $\begin{array}{l}\text { Maximum } \\
\text { slip, } m(f t)\end{array}$ & $\begin{array}{l}\text { Average } \\
\text { slip, } \\
\text { m (ft) }\end{array}$ & $\begin{array}{l}\text { Vertical } \\
\text { displace- } \\
\text { ment in } \\
\text { Adak, } \\
\text { m (ft) }\end{array}$ & $\begin{array}{l}\text { Vertical } \\
\text { displace- } \\
\text { ment in } \\
\text { Atka, } \\
\mathrm{m}(\mathrm{ft})\end{array}$ \\
\hline \multirow{3}{*}{ I } & 1 & 8.8 & $\begin{array}{l}\text { Earthquake in the Al region } \\
\text { with maximum slip at } 15-25 \\
\mathrm{~km} \text { depth and uniform along- } \\
\text { strike slip distribution }\end{array}$ & 35 (115) & $19.2(63)$ & $-1.9(-6.2)$ & $-2.1(-6.9)$ \\
\hline & 2 & 8.8 & $\begin{array}{l}\text { Earthquake in the Al region } \\
\text { with maximum slip at } 25-35 \\
\mathrm{~km} \text { depth and uniform along- } \\
\text { strike slip distribution }\end{array}$ & $\begin{array}{c}35.2 \\
(115.5)\end{array}$ & $18.1(59.4)$ & $-2.7(-8.8)$ & $-2.6(-8.5)$ \\
\hline & 3 & 8.8 & $\begin{array}{l}\text { Earthquake in the Al region } \\
\text { with maximum slip at } 35-45 \\
\mathrm{~km} \text { depth and uniform along- } \\
\text { strike slip distribution }\end{array}$ & 35 (115) & $17.4(57)$ & $-2.7(-8.8)$ & $-2.5(-8.2)$ \\
\hline \multirow{2}{*}{ II } & 4 & 8.9 & $\begin{array}{l}\text { Earthquake in the Al region } \\
\text { with maximum slip at } 15-35 \\
\mathrm{~km} \text { depth and uniform along- } \\
\text { strike slip distribution }\end{array}$ & 35 (115) & $21.2(69.5)$ & $-2.2(-7.2)$ & $-2.6(-8.5)$ \\
\hline & 5 & 8.9 & $\begin{array}{l}\text { Earthquake in the Al region } \\
\text { with maximum slip at } 25-45 \\
\mathrm{~km} \text { depth and uniform along- } \\
\text { strike slip distribution }\end{array}$ & 35 (115) & $19.6(64.3)$ & $-3.0(-9.8)$ & $-2.9(-9.5)$ \\
\hline \multirow{2}{*}{ III } & 6 & 9.1 & $\begin{array}{l}\text { Earthquake in the Al region } \\
\text { with } 35 \mathrm{~m} \text { of maximum slip } \\
\text { across the majority of the } \\
\text { rupture; uniform along-strike } \\
\text { slip distribution }\end{array}$ & 35 (115) & $33.1(108.6)$ & $-3.7(-12.1)$ & $-3.5(-11.5)$ \\
\hline & 7 & 9.1 & $\begin{array}{l}\text { Earthquake in the Al region } \\
\text { with } 50 \mathrm{~m} \text { of maximum slip } \\
\text { near the trench and } 20 \mathrm{~m} \text { of } \\
\text { slip in the rest of the rupture; } \\
\text { uniform along-strike slip } \\
\text { distribution }\end{array}$ & $50(164)$ & $35(115)$ & $-0.9(-2.9)$ & $-1.1(-3.6)$ \\
\hline \multirow[b]{2}{*}{ IV } & 8 & 9.0 & $\begin{array}{l}\text { Earthquake according to the } \\
\text { SAFRR project }\end{array}$ & 75 (250) & $16(52)$ & $0(0)$ & $0(0)$ \\
\hline & 9 & 9.1 & $\begin{array}{l}\text { Earthquake in the Cascadia } \\
\text { subduction zone along the } \\
\text { British Columbia, Washington, } \\
\text { Oregon, and northern } \\
\text { California shore }\end{array}$ & 45 (150) & $36(120)$ & $0(0)$ & $0(0)$ \\
\hline
\end{tabular}




\section{Scenario 1, Adak:}

$M_{w} 8.8$ earthquake in the Andreanof Islands region: maximum slip at a depth of $15-25 \mathrm{~km}$
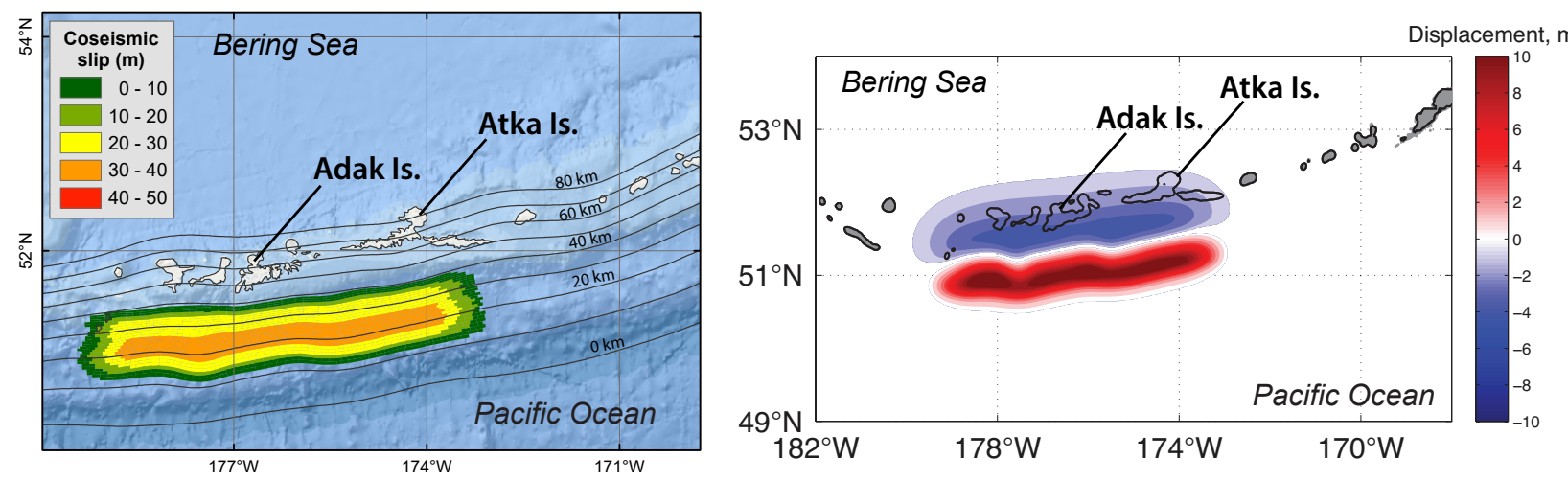

\section{Scenario 2, Adak:}

$M_{w} 8.8$ earthquake in the Andreanof Islands region: maximum slip at a depth of $25-35 \mathrm{~km}$
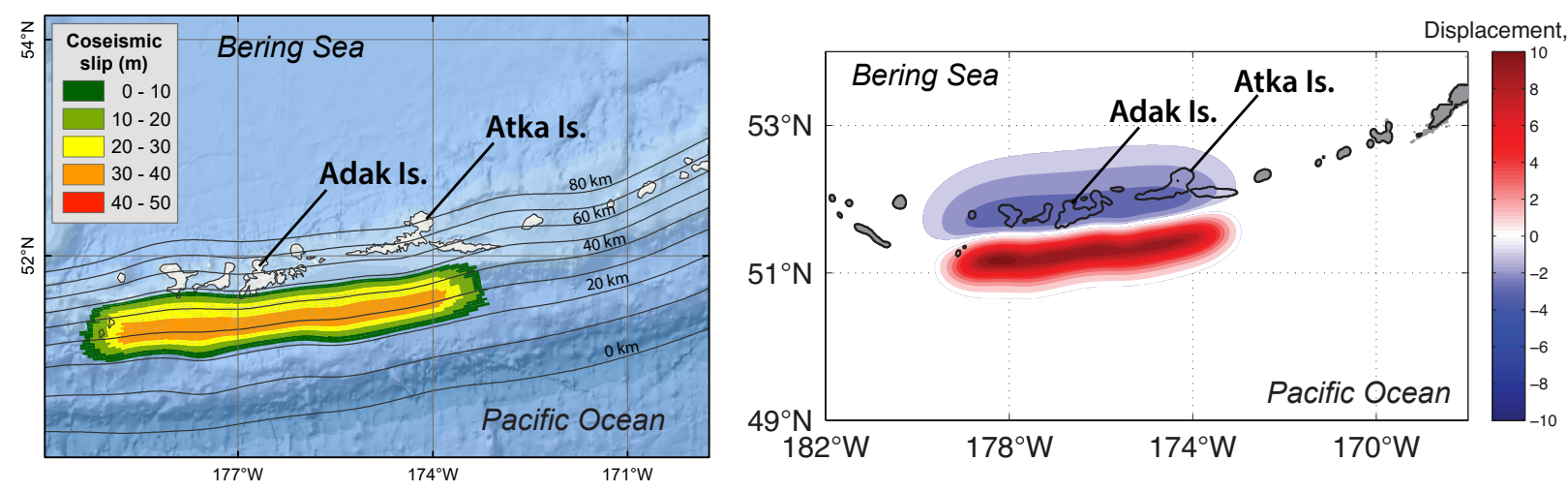

\section{Scenario 3, Adak:}

$M_{w} 8.8$ earthquake in the Andreanof Islands region: maximum slip at a depth of $35-45 \mathrm{~km}$
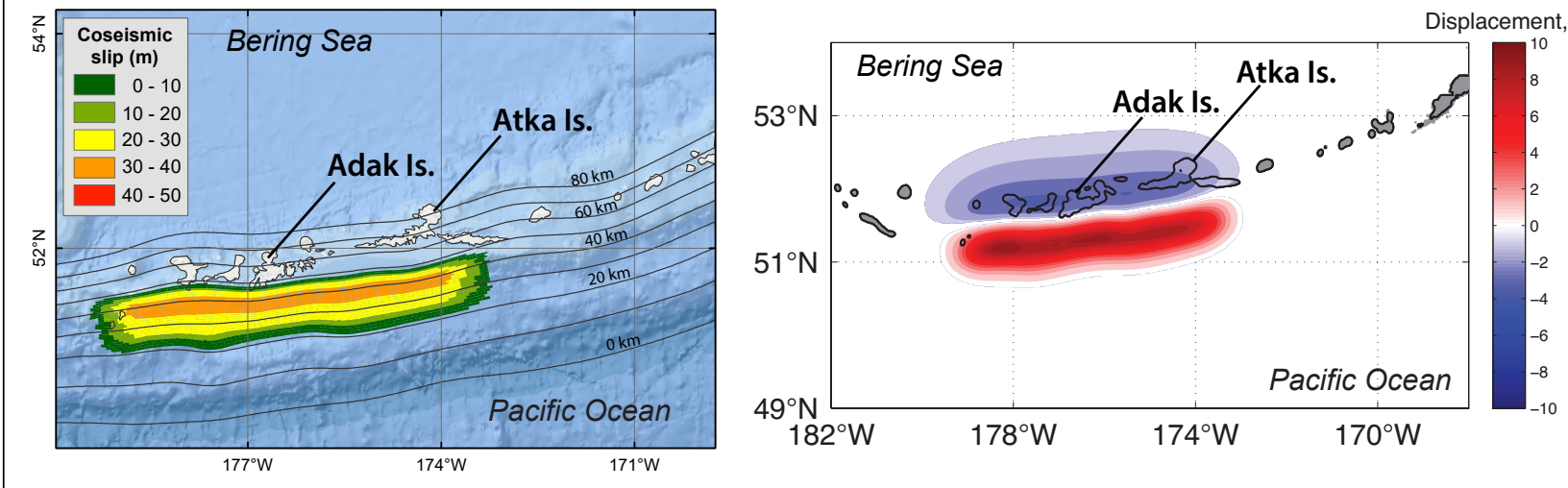

Figure 13A. Estimated slip distributions (left column) and computed vertical coseismic deformations (right column) along the plate interface for scenarios 1-3 for Adak. Depth contours of the Aleutian subduction interface are shown by black lines. Blue shaded areas are associated with coseismic ground subsidence; areas of uplift are shown in red. 


\section{Scenario 4, Adak:}

$M_{w} 8.9$ earthquake in the Andreanof Islands region: maximum slip at a depth of $15-35 \mathrm{~km}$
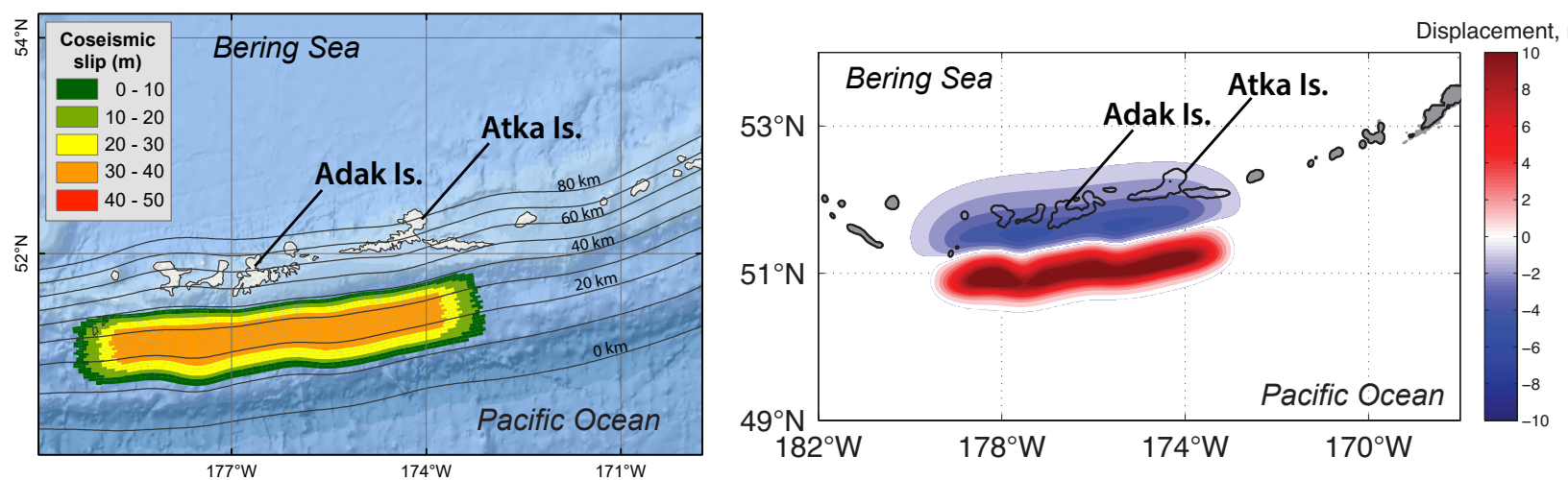

\section{Scenario 5, Adak:}

$M_{\mathrm{w}} 8.9$ earthquake in the Andreanof Islands region: maximum slip at a depth of $25-45 \mathrm{~km}$
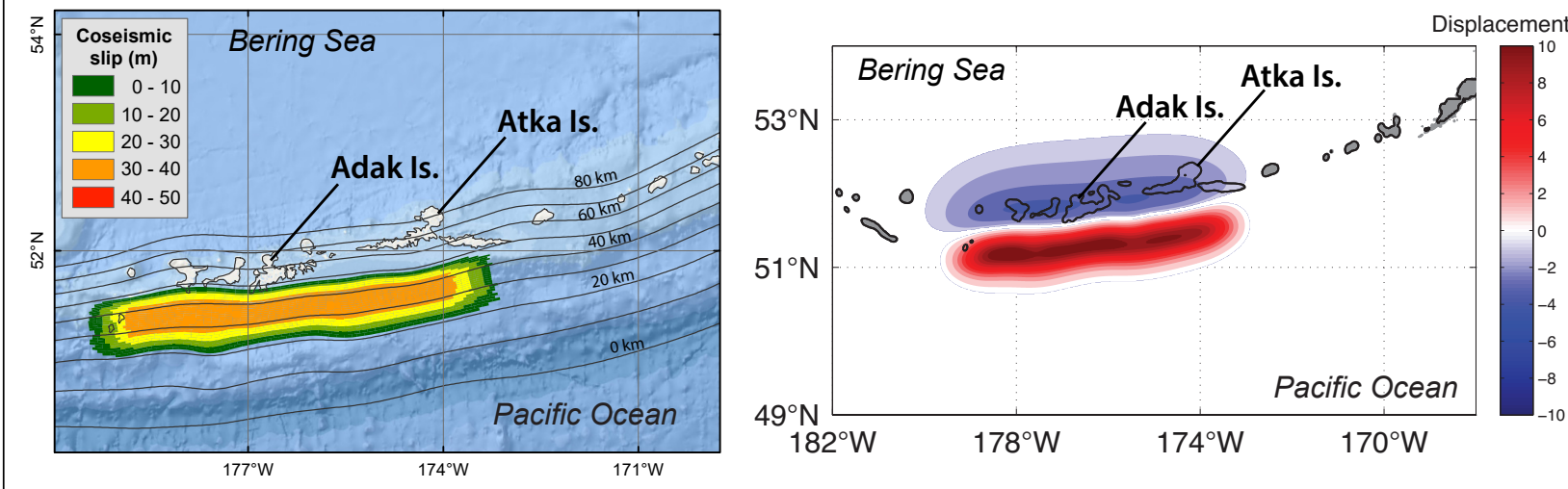

Figure 13B. Estimated slip distributions (left column) and computed vertical coseismic deformations (right column) along the plate interface for scenarios 4 and 5 for Adak. Depth contours of the Aleutian subduction interface are shown by black lines. Blue shaded areas are associated with coseismic ground subsidence; areas of uplift are shown in red. 


\section{Scenario 6, Adak:}

$M_{w} 9.1$ earthquake in the Andreanof Islands region with $35 \mathrm{~m}$ of maximum slip across the majority of the rupture.
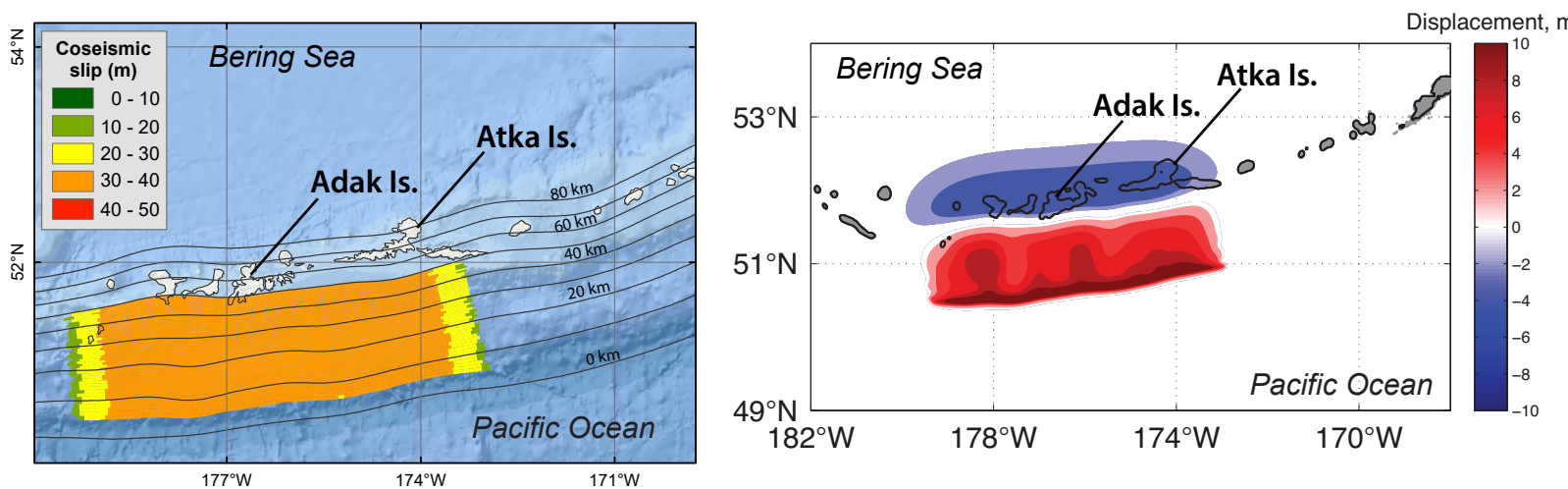

\section{Scenario 7, Adak:}

$M_{w} 9.1$ earthquake in the Andreanof Islands region with $50 \mathrm{~m}$ of maximum slip near the trench and $20 \mathrm{~m}$ of slip in the rest of the rupture
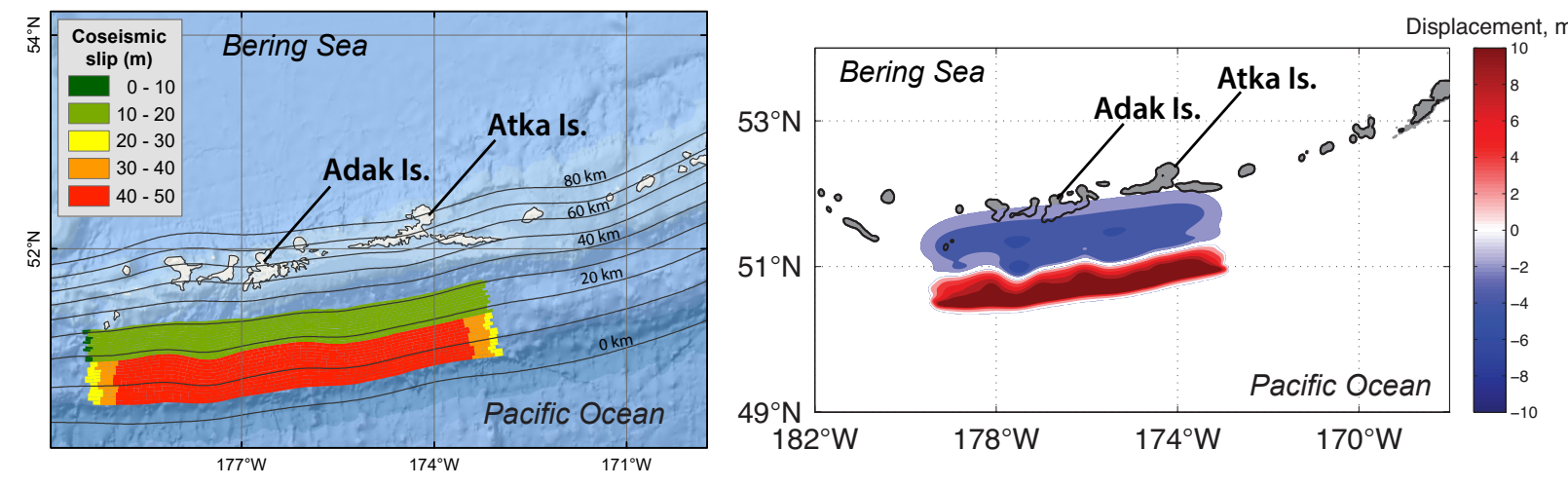

Figure 13C. Estimated slip distributions (left column) and computed vertical coseismic deformations (right column) along the plate interface for scenarios 6 and 7 for Adak. Depth contours of the Aleutian subduction interface are shown by black lines. Blue shaded areas are associated with coseismic ground subsidence; areas of uplift are shown in red. 


\section{Scenario 1, Atka:}

$M_{w} 8.8$ earthquake in the Andreanof Islands region: maximum slip at a depth of $15-25 \mathrm{~km}$
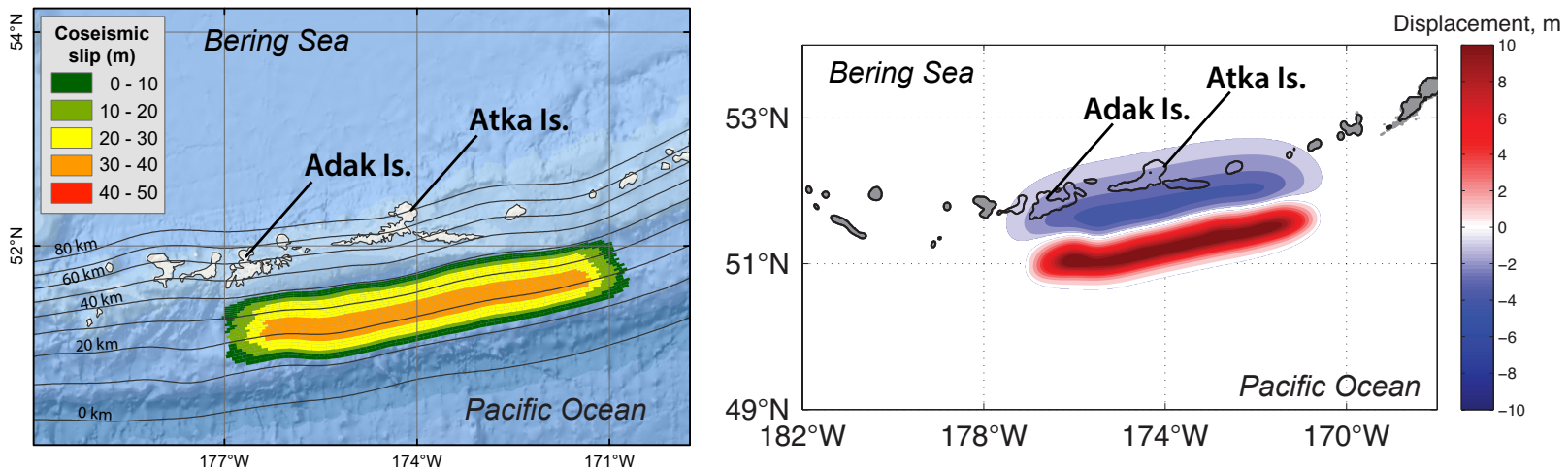

\section{Scenario 2, Atka:}

$M_{w} 8.8$ earthquake in the Andreanof Islands region: maximum slip at a depth of $25-35 \mathrm{~km}$
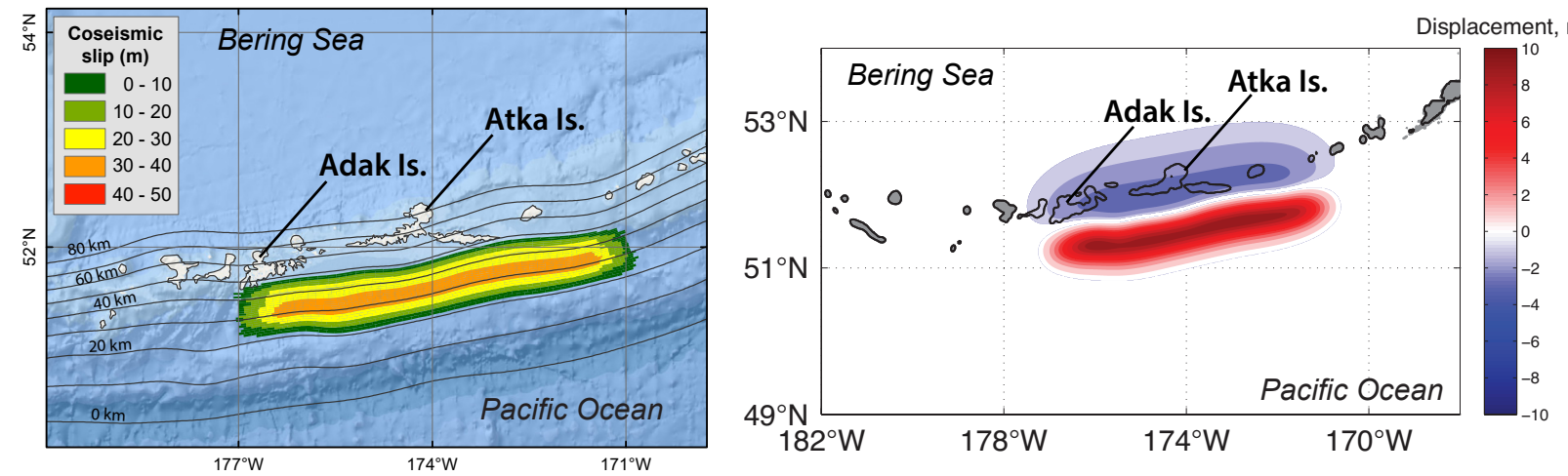

\section{Scenario 3, Atka:}

$M_{w} 8.8$ earthquake in the Andreanof Islands region: maximum slip at a depth of $35-45 \mathrm{~km}$
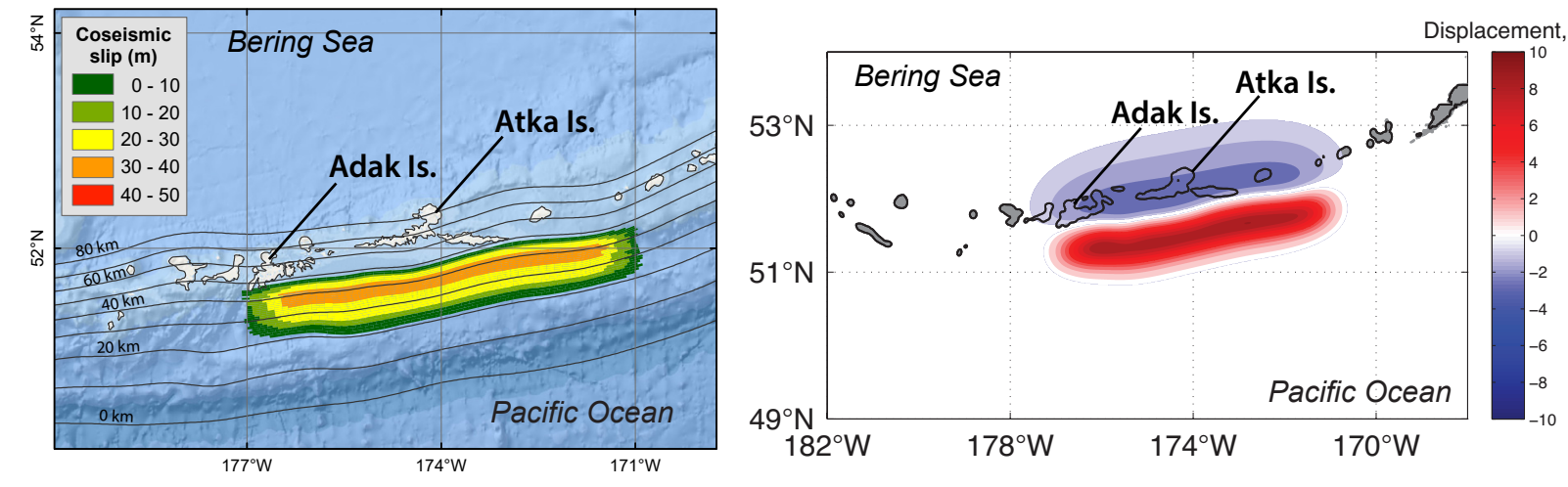

Figure 14A. Estimated slip distributions (left column) and computed vertical coseismic deformations (right column) along the plate interface for scenarios 1-3 for Atka. Depth contours of the Aleutian subduction interface are shown by black lines. Blue shaded areas are associated with coseismic ground subsidence; areas of uplift are shown in red. 


\section{Scenario 4, Atka:}

$M_{w} 8.9$ earthquake in the Andreanof Islands region: maximum slip at a depth of $15-35 \mathrm{~km}$
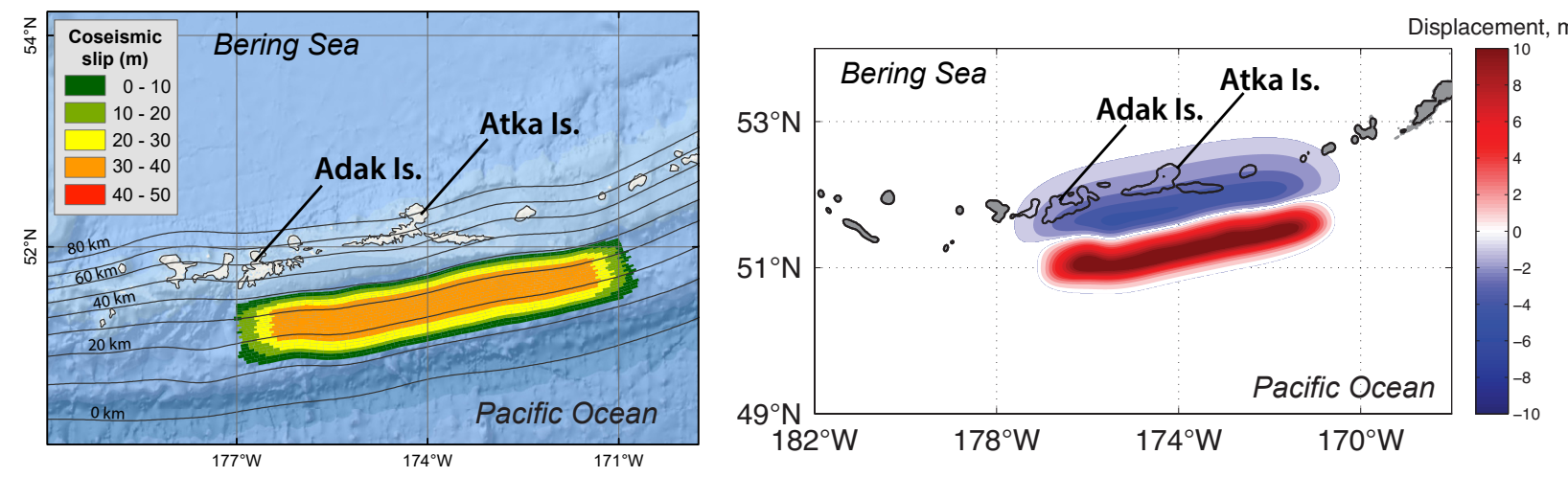

\section{Scenario 5, Atka:}

$M_{w} 8.9$ earthquake in the Andreanof Islands region: maximum slip at a depth of $25-45 \mathrm{~km}$
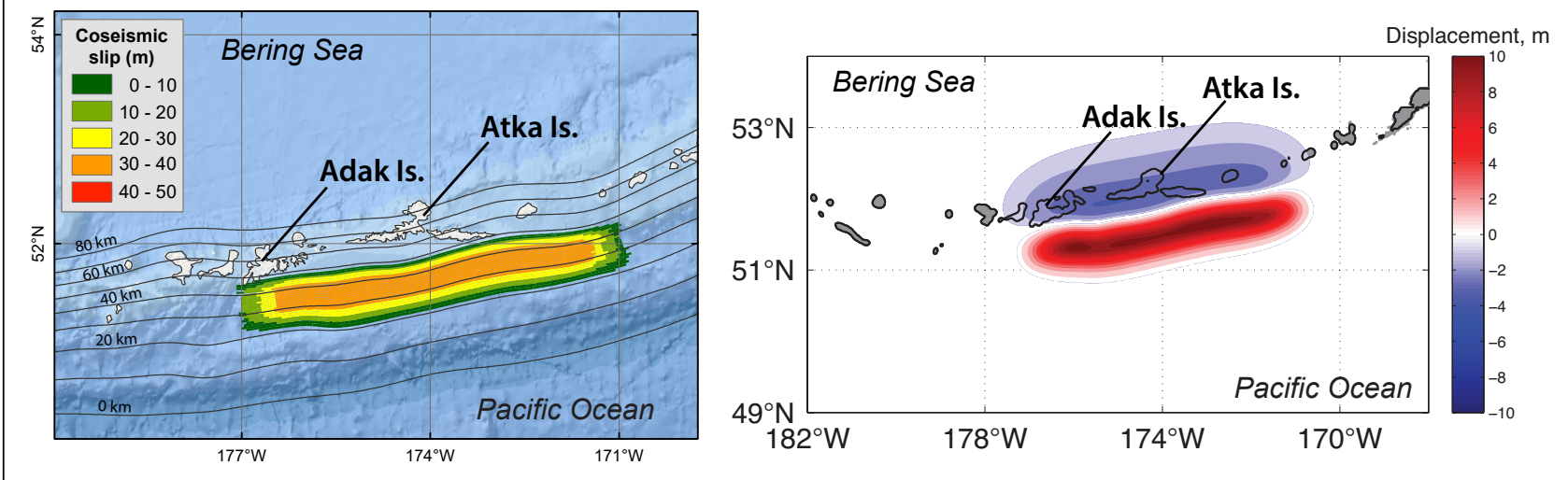

Figure 14B. Estimated slip distributions (left column) and computed vertical coseismic deformations (right column) along the plate interface for scenarios 4 and 5 for Atka. Depth contours of the Aleutian subduction interface are shown by black lines. Blue shaded areas are associated with coseismic ground subsidence; areas of uplift are shown in red. 


\section{Scenario 6, Atka:}

$M_{w} 9.1$ earthquake in the Andreanof Islands region with $35 \mathrm{~m}$ of maximum slip across the majority of the rupture.
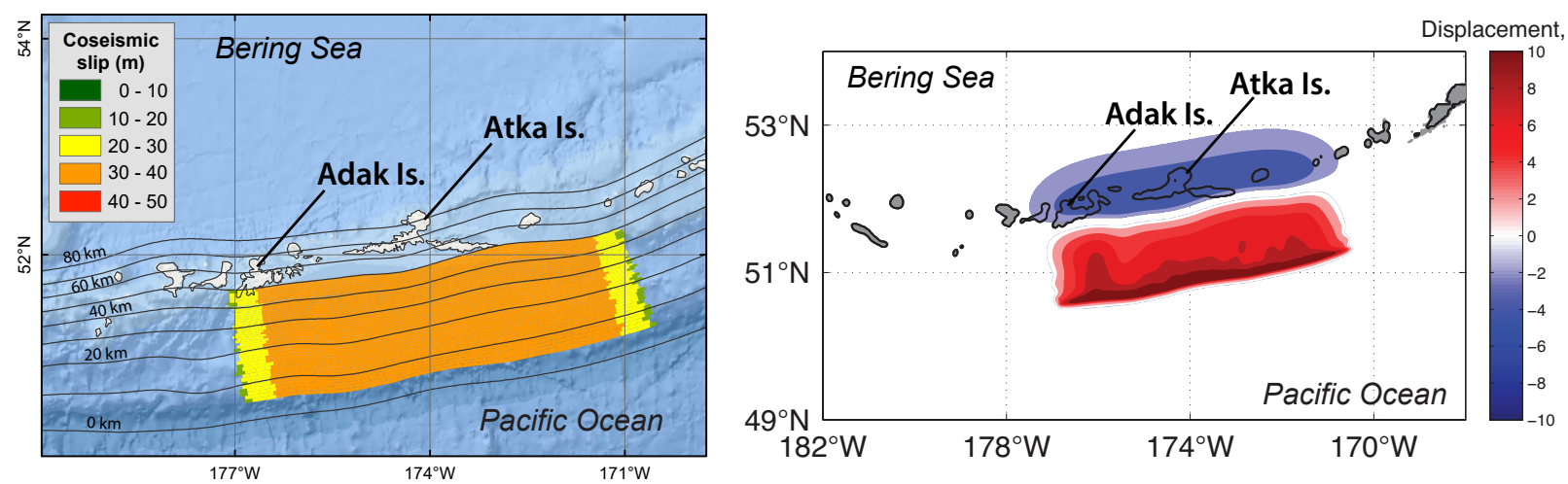

\section{Scenario 7, Atka:}

$M_{w} 9.1$ earthquake in the Andreanof Islands region with $50 \mathrm{~m}$ of maximum slip near the trench and $20 \mathrm{~m}$ of slip in the rest of the rupture
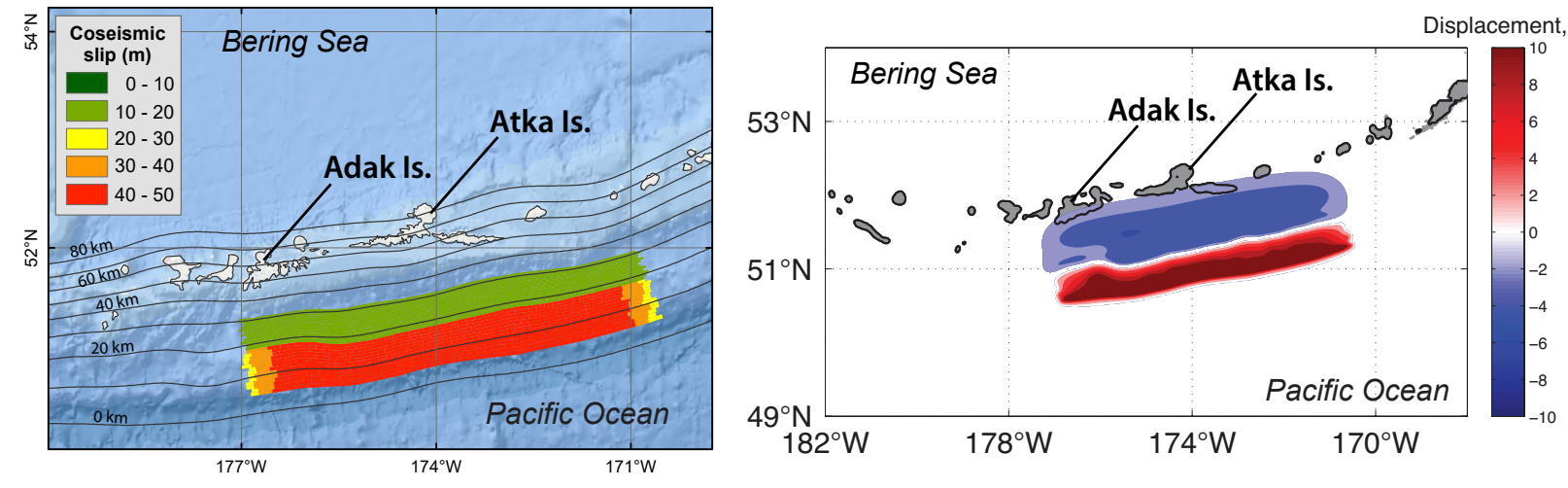

Figure 14C. Estimated slip distributions (left column) and computed vertical coseismic deformations (right column) along the plate interface for scenarios6 and 7 for Atka. Depth contours of the Aleutian subduction interface are shown by black lines. Blue shaded areas are associated with coseismic ground subsidence; areas of uplift are shown in red. 


\section{GROUP I}

Group I earthquake scenarios have maximum slip at depths based on results of the sensitivity study. In scenarios $1-3$, the maximum slip patch is $-10 \mathrm{~km}$ wide (in the down-dip direction) and is centered on the depth contours corresponding to cases B, C, and D of the sensitivity study, respectively. The average and maximum slip, as well as the rupture areas for scenarios $1-3$, are set according to the scaling relations of Papazachos and others (2005) and Moss and Travasarou (2006).

Scenario 1. $M_{W} 8.8$ earthquake in the Andreanof Islands region

Scenario 2. $M_{W} 8.8$ earthquake in the Andreanof Islands region

Scenario 3. $M_{W} 8.8$ earthquake in the Andreanof Islands region
Maximum slip at 15-25 km depth and uniform along-strike slip distribution. This scenario is based on case B of the sensitivity study.

Maximum slip at 25-35 km depth and uniform along-strike slip distribution. This scenario is based on case $C$ of the sensitivity study.

Maximum slip at 35-45 km depth and uniform along-strike slip distribution. This scenario is based on case $D$ of the sensitivity study.

\section{GROUP ||}

Group II earthquakes-scenarios 4 and 5-represent the combination of scenarios 1 and 2, and scenarios 2 and 3, respectively. Instead of having maximum slip patches $-10 \mathrm{~km}$-wide in the down-dip direction, scenarios 4 and 5 have maximum slip patches that are $-20 \mathrm{~km}$-wide in the down-dip direction, effectively combining two results from the sensitivity study. For example, scenario 4 has a $20-\mathrm{km}$ wide area of maximum slip combined from cases B and C of the sensitivity study, and scenario 5 has a $20-\mathrm{km}$ wide area of maximum slip combined from cases $\mathrm{C}$ and $\mathrm{D}$. The average and maximum slip, as well as the rupture areas for scenarios 4 and 5, are set according to the scaling relations of Papazachos and others (2005) and Moss and Travasarou (2006).

Scenario 4. $M_{W} 8.9$ earthquake in the Andreanof Islands region

Scenario 5. $M_{W} 8.9$ earthquake in the Andreanof Islands region
Maximum slip at 15-35 km depth and uniform along-strike slip distribution. This scenario is based on the combination of cases $B$ and $C$ of the sensitivity study.

Maximum slip at 25-45 km depth and uniform along-strike slip distribution. This scenario is based on the combination of cases $C$ and $D$ of the sensitivity study. 


\section{GROUP III}

The third group of scenarios is based on the potential origin of a sand layer in the Makauwahi sinkhole on the island of Kauải, Hawai'i (Butler and others, 2014). The sand is attributed to inundation by a giant paleotsunami following a $\mathrm{M}_{\mathrm{w}}$ 9+ earthquake in the eastern Aleutian Islands. Butler (2012) provides an in-depth examination of previous great Aleutian earthquakes and tsunamis impacting Hawai i. In subsequent research Butler (2014) considered several hypothetical events with $35 \mathrm{~m}$ (114.8 ft) displacement on the megathrust and up to $50 \mathrm{~m}(164.0 \mathrm{ft})$ displacement near the seafloor trench. Given implications of the March 11, 2011, $\mathrm{M}_{\mathrm{W}} 9.0$ Tohoku earthquake and tsunami (Ito and others, 2011), and given similarities between the Alaska and Tohoku subduction margins (Ryan and others, 2012; Kirby and others, 2013), it is prudent to assume that a rupture could propagate to shallow depths and produce a large amount of slip close to the seafloor trench in the Andreanof Islands region.

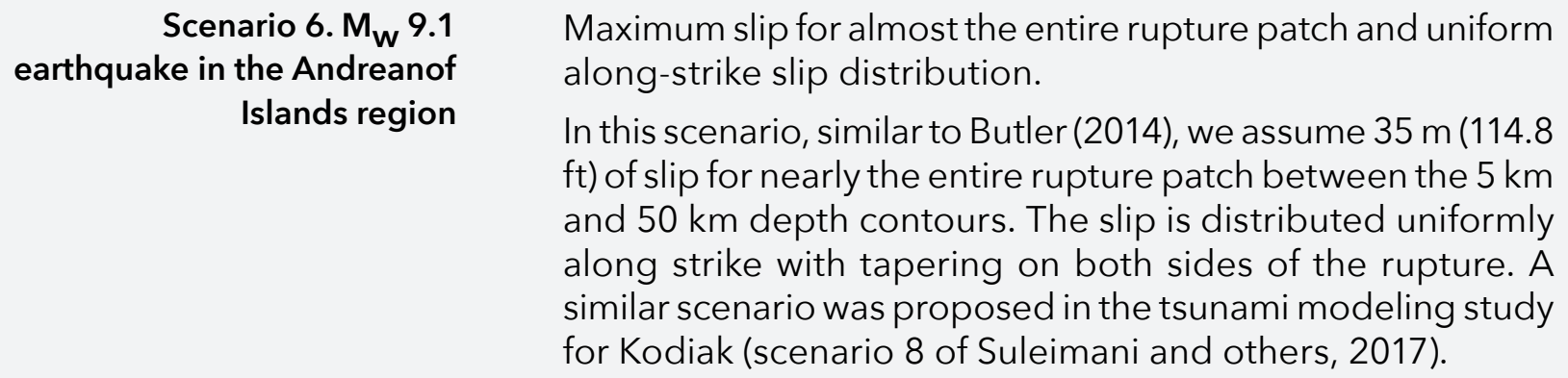

Scenario 7. $M_{w} 9.1$ earthquake in the Andreanof Islands region
$50 \mathrm{~m}$ of maximum slip near the trench and $20 \mathrm{~m}$ of slip in the rest of the rupture (Butler, 2014). The along-strike slip distribution is uniform.

A similar scenario was proposed in the tsunami modeling study for Kodiak (scenario 9 of Suleimani and others, 2017).

\section{GROUP IV}

The fourth group of tsunami scenarios includes two tsunami sources that have been considered in previous tsunami hazard reports: the USGS SAFRR tsunami scenario (Ross and Jones, 2013) and the rupture of the Cascadia subduction zone (Wang and others, 2003; Witter and others, 2011).

Scenario 8. $M_{w} 9.0$ earthquake according to the SAFRR project
Vertical coseismic deformations for this scenario are shown in figure 15.

This scenario is the same as scenario 5 in Suleimani and others' (2015) tsunami modeling study for Elfin Cove, Gustavus,

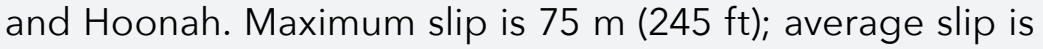
$16 \mathrm{~m}(52 \mathrm{ft})$. 
Scenario 9. $M_{w} 9.1$ earthquake in the Cascadia subduction zone along the British Columbia, Washington, Oregon, and northern California shores
Vertical coseismic deformations for this scenario are shown in figure 16. Wang and others (2003) concluded that the downdip limit of the rupture in the 1700 Cascadia earthquake could not be constrained using the tsunami heights in Japanese historical records. The authors suggested a conservative approach for Cascadia coseismic deformations assuming that full coseismic rupture takes place over the entire locked zone and the slip decreases linearly downdip halfway into the present effective transition zone. The most recently updated and probably more reasonable model assumes that the slip distribution in the downdip direction is bell-shaped (Witter and others, 2011), which is different from what was used to model the coseismic deformation shown in Wang and others (2003; figure 14). In this report, the assumed $M_{w} 9$ rupture recovers 1,200 years of plate convergence with about $36 \mathrm{~m}(118 \mathrm{ft})$ of maximum slip (Witter and others, 2011). Although a rupture of the Cascadia subduction zone is not a worst-case scenario for the Andreanof Islands area, for the sake of community preparedness we simulate a large hypothetical earthquake along the western seaboard of the U.S. This scenario is the same as scenario 16 in the tsunami modeling studies for King Cove and Cold Bay (Suleimani and others, 2016). Maximum slip is $45 \mathrm{~m}$ (148 ft); average slip is $36 \mathrm{~m}(118 \mathrm{ft})$.

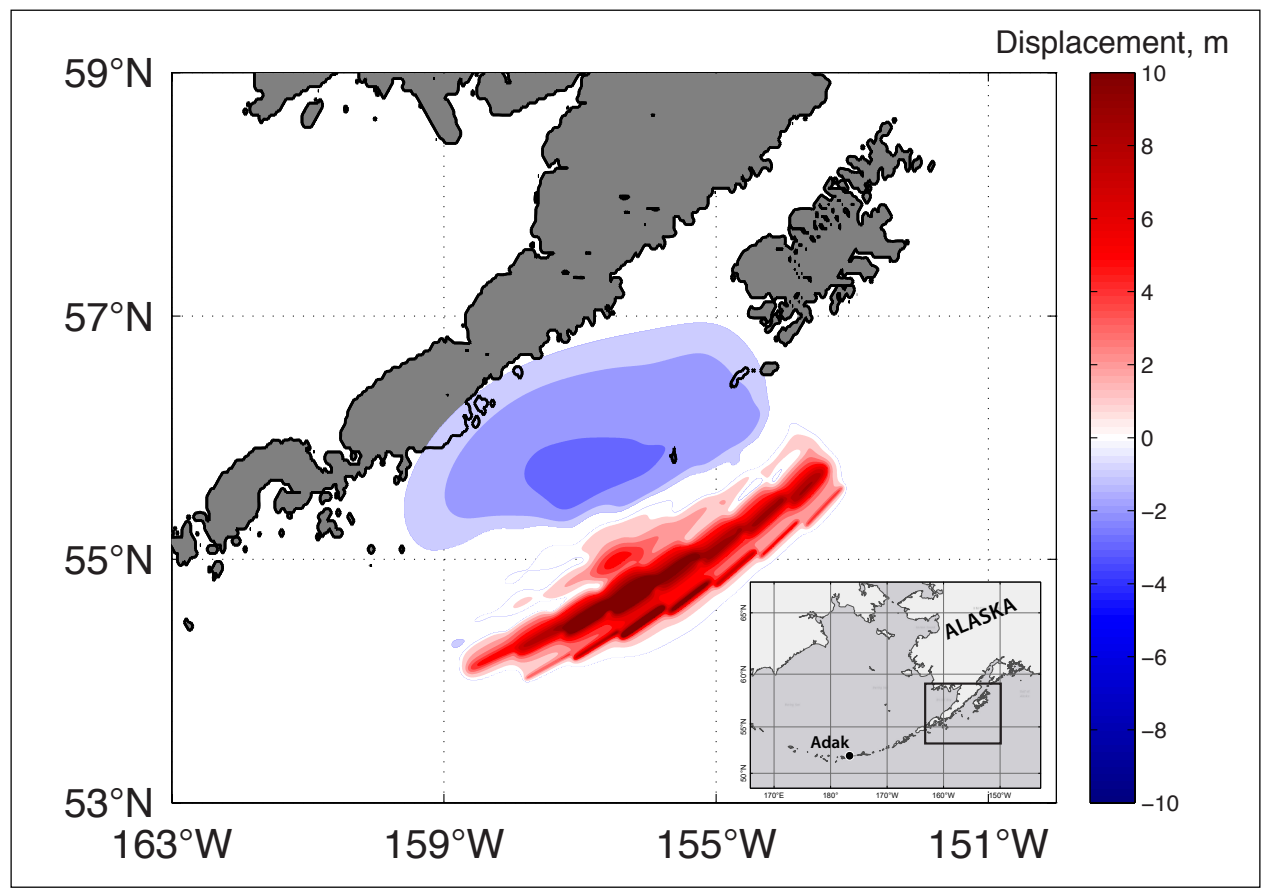

Figure 15. Computed vertical coseismic deformations for scenario 8 , a $M_{W} 9.0$ earthquake according to the SAFRR project. Blue shaded areas are associated with coseismic ground subsidence; areas of uplift are shown in red. 


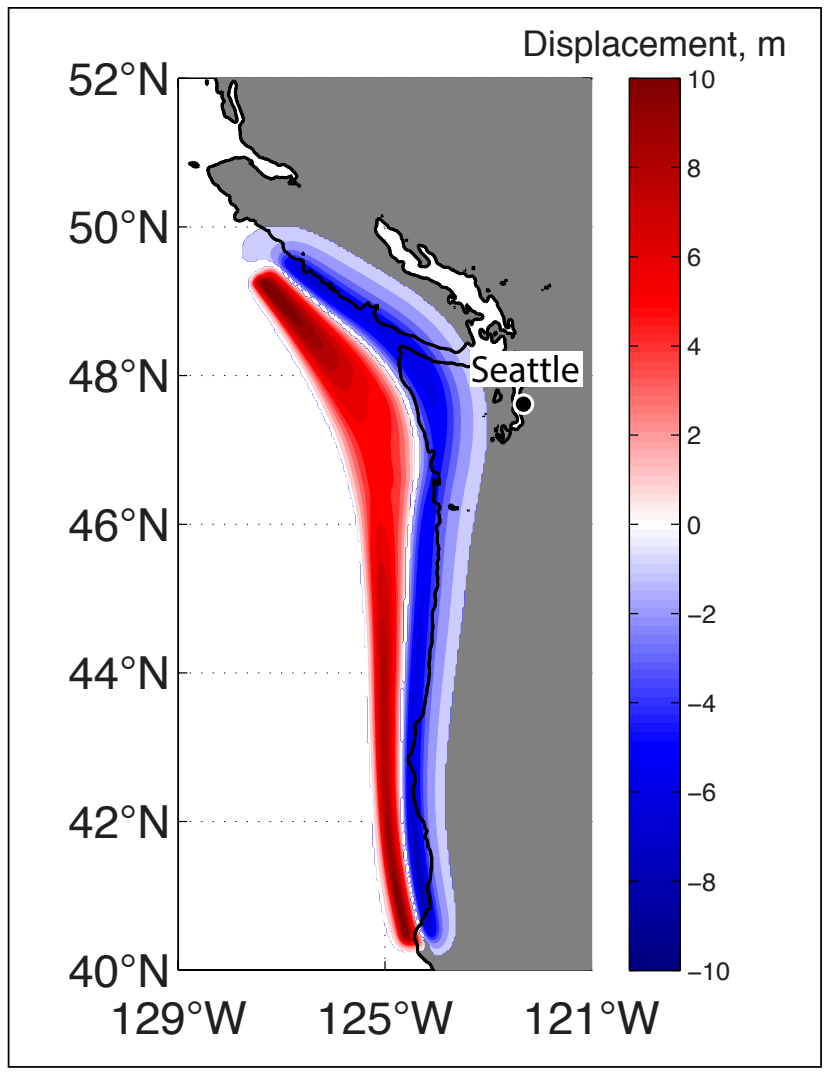

Figure 16. Computed vertical coseismic deformations for scenario 9, a $M_{W} 9.1$ earthquake in the Cascadia subduction zone along the British Columbia, Washington, Oregon, and northern California shores. Blue shaded areas are associated with coseismic ground subsidence; areas of uplift are shown in red.

\section{MODELING RESULTS}

We performed numerical simulations for nine hypothetical earthquake scenarios (table 3). Water dynamics are modeled for each grid listed in table 2 , but the extent of inundation and flow depths are calculated only for the level 4 high-resolution grids. For each scenario group, we selected the scenario that resulted in the largest inundation zone and plotted the corresponding inundation lines (figures 17 and 18).

In both Adak and Atka, scenario 6 resulted in the most significant inundation (figs. 17 and 18). The entire community of Adak (including the airport) is flooded, except for two hills_-one to the north of the subdivision centered around Kuluk Drive, and the second between the shore and the subdivision located along the Bayshore Highway. Atka is also completely inundated by scenario 6 .

Scenarios 3 and 4 inundate almost the same area in Adak as scenario 6, except for two locations. The extent of inundation for these scenarios does not reach Hillside Boulevard west of the airport, and the subdivision centered around Kuluk Drive is not flooded. In Atka, the only area that is not flooded by scenarios from the Groups I and II is the subdivision at the end of Chagix Road.

The fourth group, scenarios 8 and 9, do not result in any appreciable inundation in either community.

Map sheets 1 and 3 show the maximum extent of inundation determined from all scenarios, as well as maximum flow depths over dry land in Adak and Atka. These data reflect an ensemble of the simulated results and are calculated as follows: for each tsunami scenario, the tsunami flow depth is computed at each grid point and at every time step during the model run, and the maximum value is kept; then we compute the composite maximum flow depth from all considered scenarios by again choosing the maximum value for each grid point among all scenarios. The calculated extent of inundation includes the simulated coseismic deformation (i.e., areas of subsidence). The same approach is used to define the composite extent of tsunami inundation. Using this approach, we find that composite flow depths in both Adak and Atka reach $15 \mathrm{~m}(50 \mathrm{ft})$.

In addition to the time series of the modeled water level and velocity dynamics, we have also simulated the maximum long-term subsidence for both Adak and Atka, producing maps of semi-permanent flooding (map sheets 2 and 4). Scenario 6 results in the maximum subsidence of $3.7 \mathrm{~m}(12.1$ $\mathrm{ft})$ in Adak and $3.5 \mathrm{~m}(11.5 \mathrm{ft})$ in Atka. Based on these data, most low-lying areas in Adak could be permanently flooded for years to come as a result of this hypothetical earthquake, while the flooded area in Atka includes only a narrow band of land along the shoreline. 


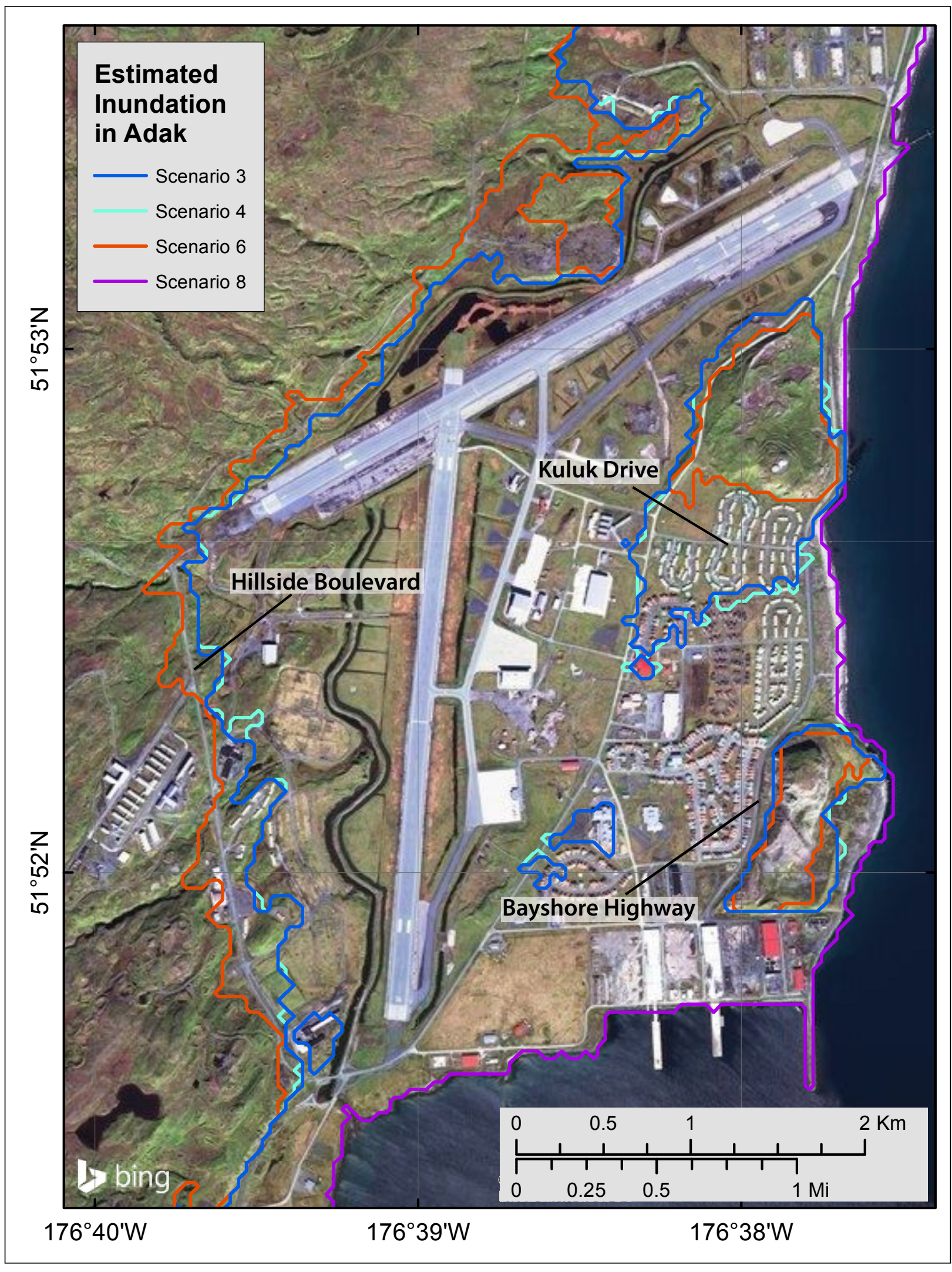

Figure 17. Modeled potential inundation in Adak for selected scenarios. Refer to table 3 for scenario parameters. 


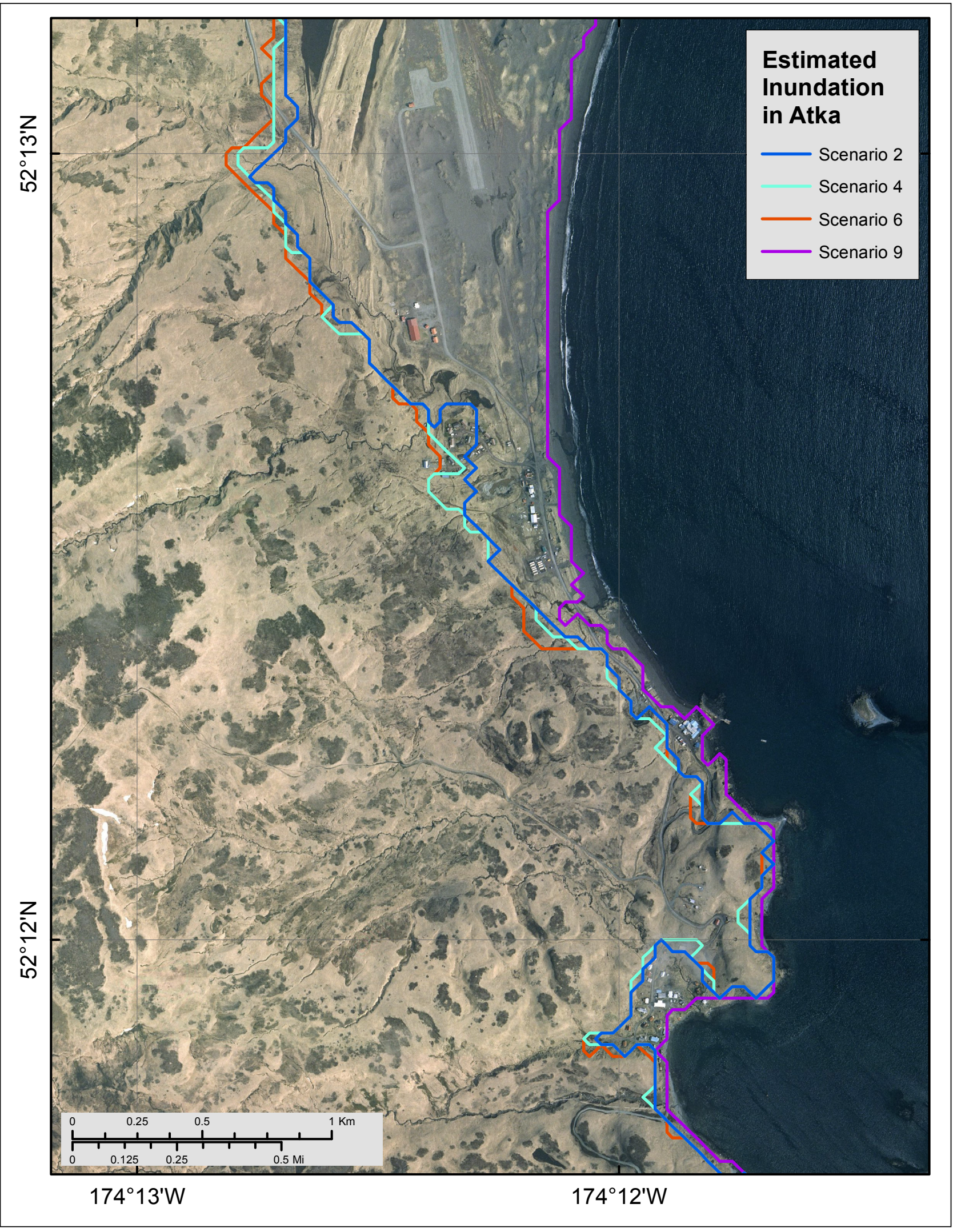

Figure 18. Modeled potential inundation in Atka for selected scenarios. Refer to table 3 for scenario parameters. 


\section{TIME SERIES AND OTHER NUMERICAL RESULTS}

We supplement the inundation maps with time series plots of modeled water levels and velocity dynamics. This information is for emergency managers to assess the duration of tsunami hazard for Adak (appendix A) and Atka (appendix B). Emergency managers should consider the arrival time of the first wave, the maximum wave amplitude, and the duration of wave action during their evacuation and response planning.

For each numbered location in figures A1 and $\mathrm{B} 1$, we plot the sea level and tsunami currents for the duration of our scenarios (figures A2-A4 and B2-B4). Time zero corresponds to the earthquake. Elevations of onshore locations and values of ocean depth at offshore locations are based on the pre-earthquake MHHW datum. Because velocity magnitude is calculated as momentum flux divided by water depth, the velocity value has large uncertainties in shallow water. In these plots, the tsunami velocity is computed only where water depth is greater than $0.3 \mathrm{~m}(1 \mathrm{ft})$.

Results reveal that in some scenarios the first wave could reach Adak and Atka as soon as 15 and 30 minutes after the earthquake, respectively. Additionally, significant wave activity could persist for at least 12 hours after the earthquake, and the predicted average time interval between successive waves is 45 minutes to 1 hour (figures A2-A4 and B2-B4).

Our maximum simulated water levels result from scenario 6 (figures A3 and B3). It reaches about $15 \mathrm{~m}(49 \mathrm{ft}$ ) at the Ferry Pier in Adak (point 2, fig. A1) and about $12 \mathrm{~m} \mathrm{(39} \mathrm{ft)} \mathrm{at} \mathrm{the} \mathrm{Cold}$ Storage in Atka (point 2, fig. B1). It takes about 30 minutes for the water level to reach its maximum height after the earthquake.

The strongest tsunami currents result from scenario 6 in Adak and scenario 1 in Atka. In Adak, currents reaching $9.8 \mathrm{~m} / \mathrm{s}(32.1 \mathrm{ft} / \mathrm{s} ; 19$ knots) occur at Seawall Road (point 8, fig. A1) about 2 hours and 20 minutes after the earthquake. In Atka, maximum currents of $11.9 \mathrm{~m} / \mathrm{s}(39 \mathrm{ft} / \mathrm{s} ; 23$ knots) occur at the Cold Storage site (point 2, fig. B1) about 5 hours after the earthquake. Tsunami activity continues for at least 12 hours after the onset of earthquake shaking. Maximum wave heights at the selected locations are listed in tables A1 and B1 for Adak and Atka, respectively.

Because tsunami impacts will persist for extended periods of time (in some cases more than 24 hours), the modeled waves depicted here will be affected by tidal fluctuations. For example, if the earthquake occurs at low tide, later tsunami oscillations may be compounded by a rising tide. In a worst-case scenario, low-lying areas that were not initially flooded may become inundated as the tide comes in.

\section{SOURCES OF ERRORS AND UNCERTAINTIES}

The hydrodynamic model used to calculate propagation and runup of tectonic tsunamis is a nonlinear, flux-formulated, shallow-water model (Nicolsky and others, 2011; Nicolsky, 2012) and has passed the required tests for official use in producing tsunami inundation maps (Synolakis and others, 2007; National Tsunami Hazard Mitigation Program [NTHMP], 2012). Most of the uncertainties in the numerical calculations originate from the tsunamigenic earthquake sources used in the models. Uncertainties in the earthquakes, such as the precise location, magnitude, and slip distribution, are the largest sources of error. The direction, amplitude, and arrival times of incoming waves are determined by the initial ocean surface conditions immediately following the earthquake. Therefore, the modeling results are particularly sensitive to the details of the tsunamigenic earthquake rupture, and when the earthquake occurs close to a community discrepancies can be exacerbated. Furthermore, our assessment of potential earthquake scenarios is by no means exhaustive, but represents a best estimate of the locations and sizes of potential tsunami-gener- 
ating events. It is possible that other unrecognized earthquake scenarios could present hazards to these communities.

The spatial resolution of grids used to calculate inundation is about $28 \mathrm{~m}(92 \mathrm{ft})$ and is high enough to describe major relief features, meeting NOAA minimum requirements for tsunami modeling (National Tsunami Hazard Mitigation Program [NTHMP], 2010). However, small topographic features are below the resolution of the current model. We also note that digital elevation models contain inherent vertical and horizontal uncertainties that are propagated into modeling results. The depictions of inundation are by no means absolute. One major contributor to uncertainty is the paucity of data in the intertidal zone. The current practice is to create some additional buffer area around the inundation line to use for hazard mitigation and decisions related to tsunami evacuation. However, no established practices exist to directly propagate the DEM uncertainty into the uncertainty of the inundation line (Hare and others, 2011).

\section{SUMMARY}

We present results of numerically modeled hypothetical tectonic tsunami waves for Adak and Atka. Each scenario is geologically reasonable and several of them present potential significant hazard to the communities. Scenario 6, a megathrust earthquake in the Andreanof Islands region with maximum slip at a depth of $15-25 \mathrm{~km}$, produces the largest inundation area in both Adak and Atka. The maximum predicted tsunami wave height is $10-15$ m (33-50 ft) in both Adak and Atka. The numerical simulations reveal that for some scenarios the first wave could reach Adak and Atka as soon as 15 and 30 minutes after the earthquake, respectively. Significant wave activity is likely to continue in the area for at least 12 hours after the earthquake; the predicted average time interval between successive waves is 45 minutes to 1 hour.

The maps that are part of this report have been completed using the best available information. However, in preparing these maps many assumptions have been made. We considered a suite of tsunami inundation scenarios and, based on these data, have developed an estimate of the maximum credible tsunami inundation. Actual conditions during a tsunami event may vary, so the report's accuracy cannot be guaranteed. The depicted inundation limits should be used as a guideline for emergency planning and response action. Inundation during an actual event will depend on earthquake specifics, on-land construction, and tide level, and may differ from areas shown on map sheets. The results are intended to assist state and local agencies in planning for emergency evacuation and tsunami response actions in the event of a major tsunamigenic earthquake. These results are not intended for land-use regulation or building-code development.

\section{ACKNOWLEDGMENTS}

This report was funded by Award NA15NWS4670027 by a National Tsunami Hazard Mitigation Program grant to Alaska Division of Homeland Security and Emergency Management and University of Alaska Fairbanks from the Department of Commerce/National Oceanic at Atmospheric Administration. This does not constitute an endorsement by NOAA. Numerical calculations for this work were supported by High Performance Computing (HPC) resources at the Research Computing Systems unit at the Geophysical Institute, University of Alaska Fairbanks. We are grateful to Jonathan Allan and Richard Koehler for their valuable comments and suggestions that helped improve the report. 


\section{REFERENCES}

Butler, Rhett, 2012, Re-examination of the potential for great earthquakes along the Aleutian island arc with implication for tsunamis in Hawai'i: Seismological Research Letters, v. 83, no. 1, p. 30-39. doi.org/10.1785/gssrl.83.1.29

2014, Great Aleutian tsunamis: Honolulu, HI, University of Hawai' $i$ at Manoa, Hawai' $i$ Institute of Geophysics \& Planetology, PeerReviewed Report HIGP-2014-1, 170 p. www. higp.hawaii.edu/reports/2014

Butler, Rhett, Burney, D., and Walsh, D. 2014, Paleo-tsunami evidence on Kaua'i and numerical modeling of a great Aleutian tsunami: Geophysical Research Letters, v. 41, no. 19, p. 6,795-6,802. doi.org/10.1002/2014GL061232

Carignan, K.S., Taylor, L.A., Eakins, B.W., Warnken, R.R., Medley, P.R., and Lim, E., 2009, Digital elevation model of Adak, Alaska-Procedures, data sources and analysis: National Oceanic and Atmospheric Administration Technical Memorandum NESDIS NGDC-31, U.S. Dept. of Commerce, Boulder, CO, 29 p. www.ngdc. noaa.gov/dem/squareCellGrid/download/258

Cross, R.S., and Freymueller, J.T., 2007, Plate coupling variation and block translation in the Andreanof segment of the Aleutian arc determined by subduction zone modeling using GPS data: Geophysical Research Letters, Solid Earth, v. 34, no. 6, L06304, 5 p. doi.org/10.1029/2006GL028970

2008, Evidence for and implications of a Bering plate based on geodetic measurements from the Aleutians and western Alaska, Journal of Geophysical Research, v. 113, no. B7, 19 p. doi.org/10.1029/2007JB005136

Department of Commerce, Community, and Economic Development (DCCED)/Division of Community and Regional Affairs (DCRA), 2015, Community Database Online, accessed November 22, 2016. dcra-cdo-dcced.opendata. arcgis.com/

Dunbar, P.K., and Weaver, C.S., 2008, U.S. states and territories national tsunami hazard assessment-Historical record and sources for waves: Technical Report, National Oceanic and
Atmospheric Administration and U.S. Geological Survey, 59 p. nthmp.tsunami.gov/documents/ Tsunami_Assessment_Final.pdf

Friday, D.Z., Taylor, L.A., Eakins, B.W., Carignan, K.S., Caldwell, R.J., Grothe, P.R., and Lim, E., 2011, Digital elevation model of Atka, AlaskaProcedures, data sources and analysis: Boulder, CO, U.S. Department of Commerce, NOAA Technical Memorandum NESDIS NGDC-48, 20 p. www.ngdc.noaa.gov/dem/squareCellGrid/ download/252

Hare, Rob, Eakins, Barry, Amante, Chris, and Taylor, L.A., 2011, Modeling bathymetric uncertainty: US HYDRO 2011 conference, Tampa, FL, April 25-28, 2011, Proceedings. ushydro.thsoa.org/ us11 papers.htm

Hayes, G.P., Wald, D.J., and Johnson, R.L., 2012, Slab1.0-A three-dimensional model of global subduction zone geometries: Journal of Geophysical Research, v. 117, no. B1, 15 p. doi.og/10.1029/2011JB008524

Ito, Y., Tsuji, T., Osada, Y., Kido, M., Inazu, D., Hayashi, Y., Tsushima, H., Hino, R., and Fujimoto, H., 2011, Frontal wedge deformation near the source region of the 2011 Tohoku-Oki earthquake: Geophysical Research Letters, v. 38, no. 7, 5 p. doi.org/10.1029/2011GL048355

Johnson, J.M., Tanioka, Yuichiro, Ruff, L.J., Satake, Kenji, Kanamori, Hiroo, and Sykes, L.R., 1994, The 1957 great Aleutian earthquake: Pure and Applied Geophysics, v. 142, no. 1, p. 3-28. doi.org/10.1007/BF00875966

Kirby, Stephen, Scholl, David, von Huene, Roland, and Wells, Ray, 2013, Alaska earthquake source for the SAFRR tsunami scenario, chapter $B$, in Ross, S.L., and Jones, L.M., eds., The SAFRR (Science Application for Risk Reduction) Tsunami Scenario: U.S. Geological Survey OpenFile Report 2013-1170, 40 p. pubs.usgs.gov/ of/2013/1170/b/

Lander, J.F., 1996, Tsunamis affecting Alaska, 1737-1996: Boulder, CO, National Oceanic and Atmospheric Administration, National Geophysical Data Center (NGDC), Key to Geophysical Research Documentation, v. 31, 155 p. ftp://ftp.ngdc.noaa.gov/hazards/publications/ Kgrd-31.pdf 
Lim, E., Eakins, B.W., and Wigley, R., 2011, Coastal relief model of southern Alaska-Procedures, data sources and analysis: National Oceanic and Atmospheric Administration (NOAA) Technical Memorandum NESDIS NGDC43, 22 p. docs.lib.noaa.gov/noaa_documents/ NESDIS/NGDC/TM/NOAA_TM_NESDIS_ NGDC_43.pdf

Moss, Robb E.S., and Travasarou, Thaleia, 2006, Tsunamigenic probabilistic fault displacement hazard analysis for subduction zonesProceedings of the 8th U.S. National Conference on Earthquake Engineering: Earthquake Engineering Research Institute, Paper 238, 9 p.

National Centers for Environmental Information (NCEI/WDS), in progress, Global historical tsunami database at NCEI, $2100 \mathrm{BC}$ to present (interactive map): National Centers for Environmental Information, NOAA. doi.org/10.7289/V5PN93H7

National Tsunami Hazard Mapping Program (NTHMP), 2010, Guidelines and best practices for tsunami inundation modeling for evacuation planning: National Oceanic and Atmospheric Administration (NOAA), NTHMP Mapping \& Modeling Subcommittee.

National Tsunami Hazard Mapping Program (NTHMP), 2012, Proceedings and results of the 2011 NTHMP Model Benchmarking Workshop: Boulder, CO, U.S. Department of Commerce/NOAA/NTHMP, NOAA Special Report, 436 p. nthmp.tsunami.gov

Nicolsky, D.J., 2012, Alaska tsunami model, in Proceedings and Results of the 2011 NTHMP Model Benchmarking Workshop: Boulder, CO, U.S. Department of Commerce/NOAA/ NTHMP, NOAA Special Report, p. 55-87. nthmp.tsunami.gov

Nicolsky, D.J., Suleimani, E.N., Freymueller, J.T., and Koehler, R.D., 2015, Tsunami inundation maps of Fox Islands communities, including Dutch Harbor and Akutan, Alaska: Alaska Division of Geological \& Geophysical Surveys Report of Investigation 2015-5, 67 p., 2 sheets, scale $1: 12,500$. doi.org/10.14509/29414

Nicolsky, D.J., Suleimani, E.N., and Hansen, R.A.,
2011, Validation and verification of a numerical model for tsunami propagation and runup: Pure and Applied Geophysics, v. 168, no. 6, p. 1,1991,222. doi.org/10.1007/s00024-010-0231-9

Nicolsky, D.J., Suleimani, E.N., and Koehler, R.D., 2016, Tsunami inundation maps for the communities of Chignik and Chignik Lagoon, Alaska: Alaska Division of Geological \& Geophysical Surveys Report of Investigation 2016-8, 48 p., 2 sheets, scale 1:12,500. doi.org/10.14509/29675

Nicolsky, D.J., Suleimani, E.N., Koehler, R.D., and Salisbury, J.B., 2017, Tsunami inundation maps for Juneau, Alaska: Alaska Division of Geological \& Geophysical Surveys Report of Investigation 2017-9, 66 p., 5 sheets. doi.org/10.14509/29741 Okada, Yoshimitsu, 1985, Surface deformation due to shear and tensile faults in a half-space: Bulletin of the Seismological Society of America, v. 75, no. 4, p. 1,135-1,154.

Papazachos, B.C., Scordilis, E.M., Panagiotopoulos, D.G., Papazachos, C.B., and Karakaisis, G.F., 2005, Global relations between seismic fault parameters and moment magnitude of earthquakes: Bulletin of the Geological Society of Greece, v. 36, p. 1,482-1,489.

Ross, S.L., and Jones, L.M., eds., 2013, The SAFRR Tsunami Scenario: U.S. Geological Survey Open-File Report 2013-1170, 897 p. pubs.usgs.gov/of/2013/1170/

Ryan, Holly, von Huene, Roland, Scholl, Dave, and Kirby, Steve, 2012, Tsunami hazards to U.S. coasts from giant earthquakes in Alaska: Eos Transactions, American Geophysical Union, v. 93, no. 19, p. 185-186.

Shao, Guangfu, Li, Xiangyu, Ji, Chen, and Maeda, Takahiro, 2011, Focal mechanism and slip history of $2011 \mathrm{M}_{\mathrm{W}} 9.1$ off the Pacific coast of Tohoku earthquake, constrained with teleseismic body and surface waves: Earth Planets and Space, v. 63 , no. 7 , p. 559-564. doi.org/10.5047/ eps.2011.06.028

Suleimani, E.N., Combellick, R.A., Marriott, D., Hansen, R.A., Venturato, A.J., and Newman, J.C., 2005, Tsunami hazard maps of the Homer and Seldovia areas, Alaska: Alaska Division 
of Geological \& Geophysical Surveys Report of Investigation 2005-2, 28 p., 2 sheets, scale 1:12,500. doi.org/10.14509/14474

Suleimani, E.N., Nicolsky, D.J., and Koehler, R.D., 2015, Tsunami inundation maps of Elfin Cove, Gustavus, and Hoonah, Alaska: Alaska Division of Geological \& Geophysical Surveys Report of Investigation 2015-1, 79 p., 3 sheets. doi.org/10.14509/29404

2017, Updated tsunami inundation maps of the Kodiak area, Alaska: Alaska Division of Geological \& Geophysical Surveys Report of Investigation 2017-8, 38 p., 10 sheets. doi.org/10.14509/29740

Suleimani, E.N., Nicolsky, D.J., Koehler, R.D., Freymueller, J.T., and Macpherson, A.E., 2016, Tsunami inundation maps for King Cove and Cold Bay communities, Alaska: Alaska Division of Geological \& Geophysical Surveys Report of Investigation 2016-1, 73 p., 2 sheets, scale 1:12,500. doi.org/10.14509/29565

Synolakis, C.E., Bernard, E.N., Titov, V.V., Kânoğlu, U., and González, F.I., 2007, Standards, criteria, and procedures for NOAA evaluation of tsunami numerical models: Seattle, National Oceanic and Atmospheric Administration (NOAA)/Pacific Marine Environmental Laboratory (PMEL), Technical Memorandum OAR PMEL-135, 55 p. $\quad$ www.pmel.noaa.gov/pubs/PDF/syno3053/ syno3053.pdf

Tang, Liujuan, Titov, V.V., Bernard, E.N., Wei, Yong, Chamberlin, C.D., Newman, J.C.,
Mofjeld, H.O., Arcas, Diego, Eble, M.C., Moore, Christopher, Uslu, Burak, Pells, Clint, Spillane, Michael, Wright, Lindsey, and Gica, Edison, 2012, Direct energy estimation of the 2011 Japan tsunami using deep-ocean pressure measurements: Journal of Geophysical Research, v. 117, no. C8, 28 p. doi.org/10.1029/2011JC007635

Tanioka, Yuichiro, and Gonzalez, F.I., 1998, The Aleutian earthquake of June 10, $1996\left(\mathrm{M}_{\mathrm{W}} 7.9\right)$ ruptured parts of both the Andreanof and Delarof segments: Geophysical Research Letters, v. 25, no. 12, p. 2,245-2,248. doi.org/10.1029/98GL01578 Wang, Kelin, Wells, R.E., Mazzotti, Stephane, Hyndman, R.D., and Sagiya, Takeshi, 2003, A revised dislocation model of interseismic deformation of the Cascadia subduction zone: Journal of Geophysical Research, v. 108, no. B1, p. 2,026-2,038. doi.org/10.1029/2001JB001227

Watada, S., S. Kusumoto, and K. Satake, 2014, Traveltime delay and initial phase reversal of distant tsunamis coupled with the self-gravitating elastic Earth, JGR Solid Earth, v. 119, no. 5, p. 4,287-4,310. doi.org/10.1002/2013JB010841

Witter, R.C., Zhang, Y., Wang, K., Priest, G.R., Goldfinger, C., Stimely, L.L., English, J.T., and Ferro, P.A., 2011, Simulating tsunami inundation at Bandon, Coos County, Oregon, using hypothetical Cascadia and Alaska earthquake scenarios: Oregon Department of Geology and Mineral Industries Special Paper $43,57 \mathrm{p}$. 


\section{APPENDIX A}

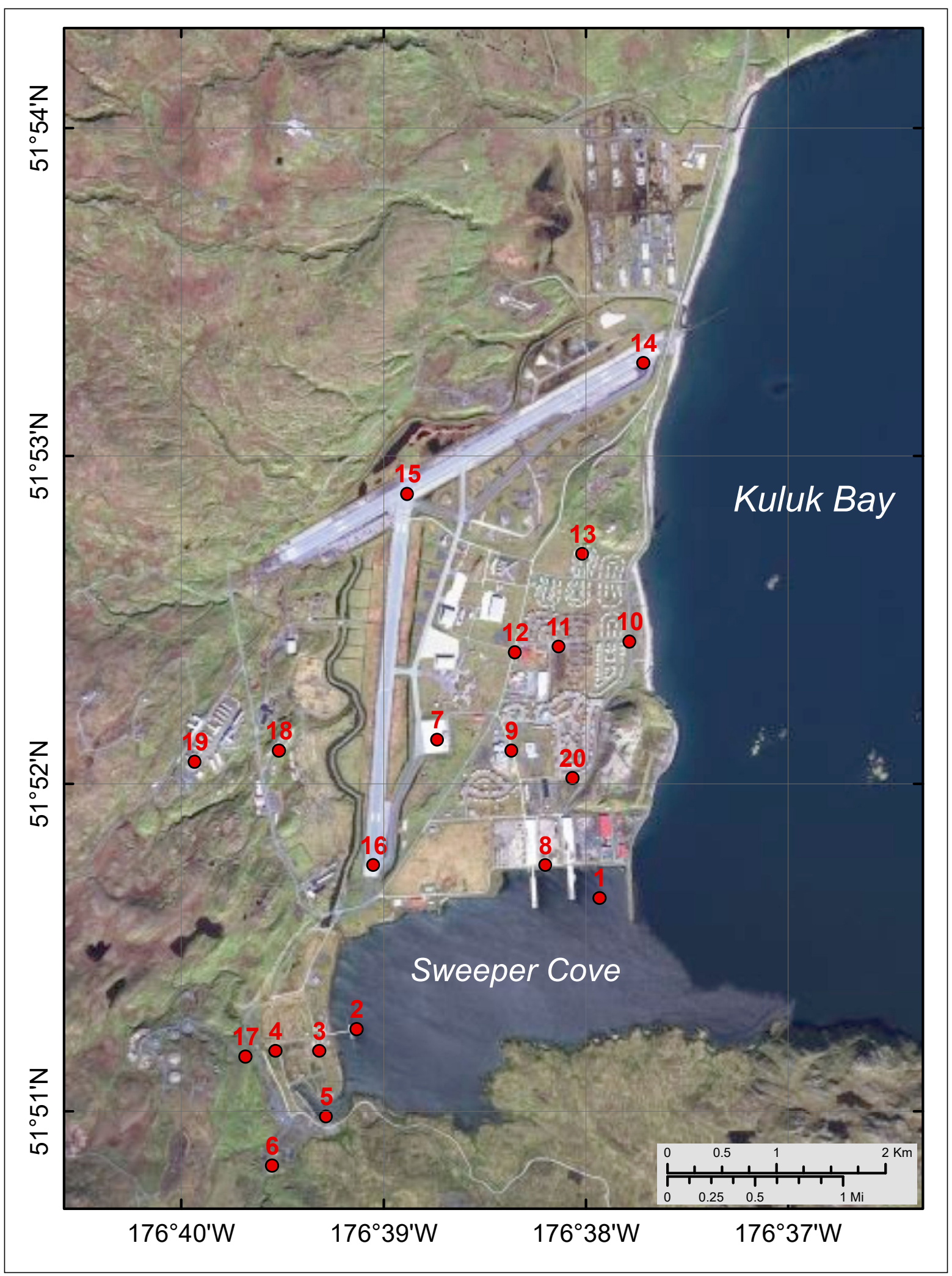

Figure A1. Locations of time series points in Adak. The longitudinal and latitudinal coordinates of the time series points are listed in table A1. 


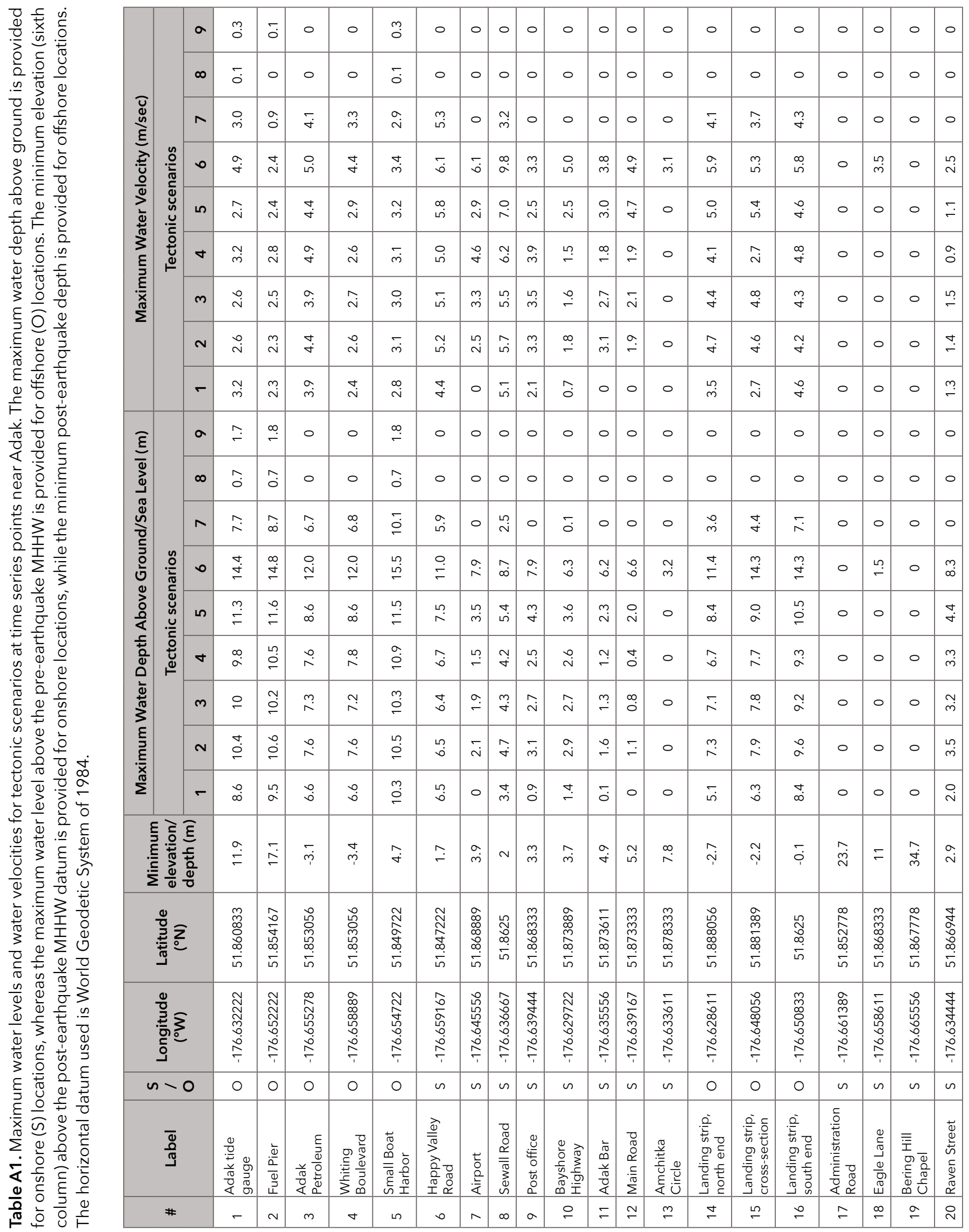




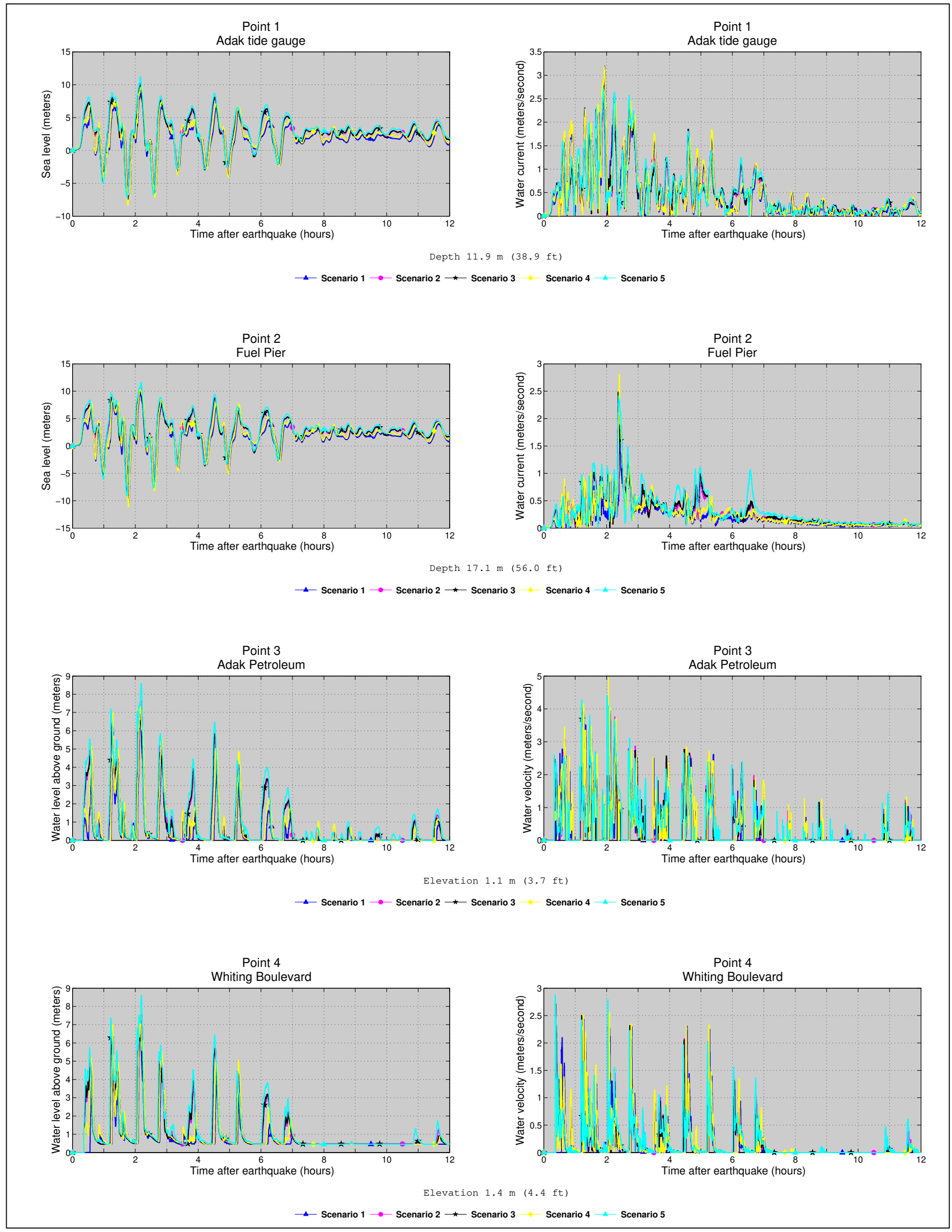

Figure A2. Time series of water level (left) and velocity (right) for scenarios 1-5 at Adak locations shown in figure A1. The pre-earthquake elevation/depth with respect to the MHHW is stated for each location. For offshore locations, to show the height of an arriving tsunami, the vertical datum is such that zero corresponds to the pre-earthquake sea level. 


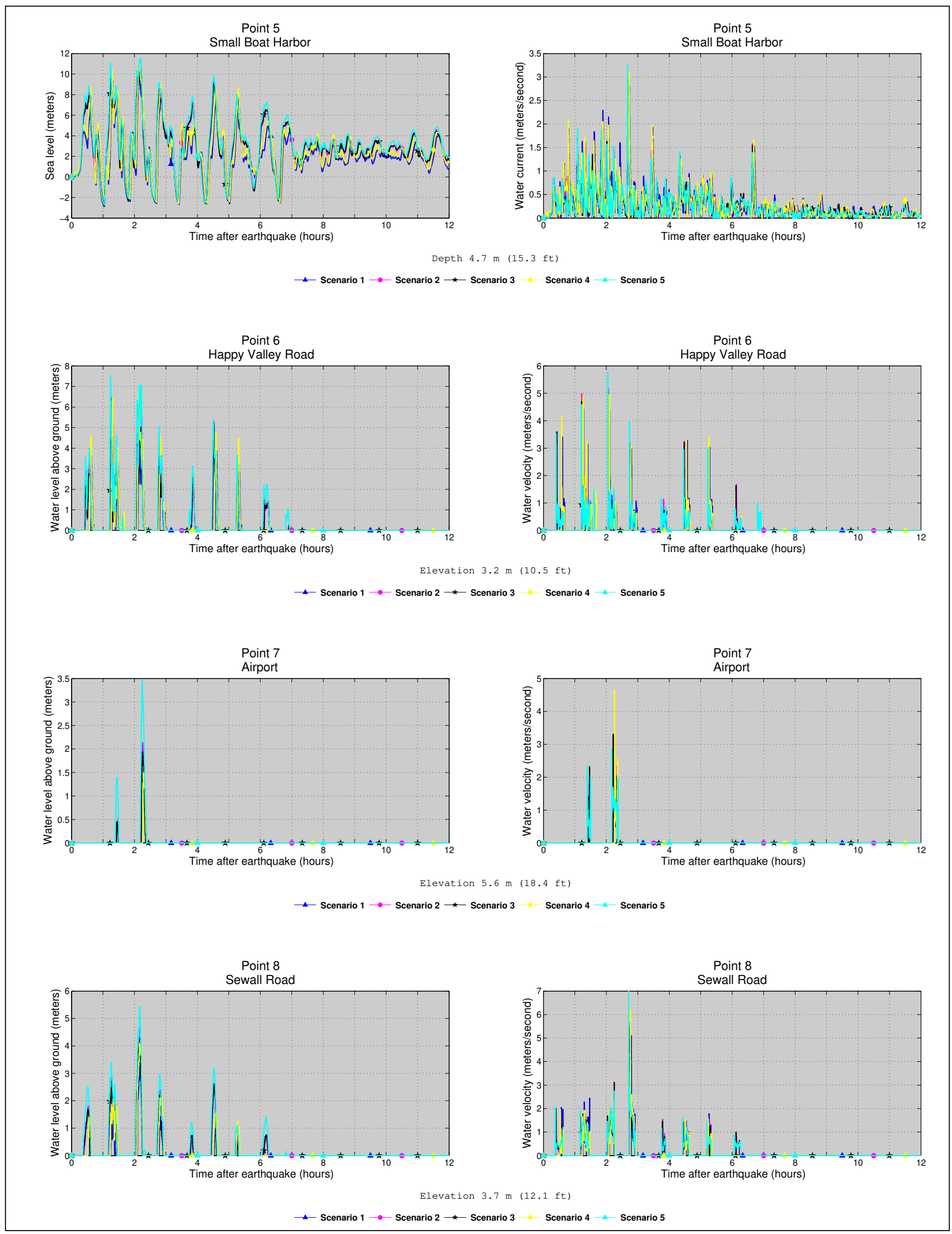

Figure A2, continued. Time series of water level (left) and velocity (right) for scenarios 1-5 at Adak locations shown in figure A1. The pre-earthquake elevation/depth with respect to the $\mathrm{MHHW}$ is stated for each location. For offshore locations, to show the height of an arriving tsunami, the vertical datum is such that zero corresponds to the pre-earthquake sea level. 


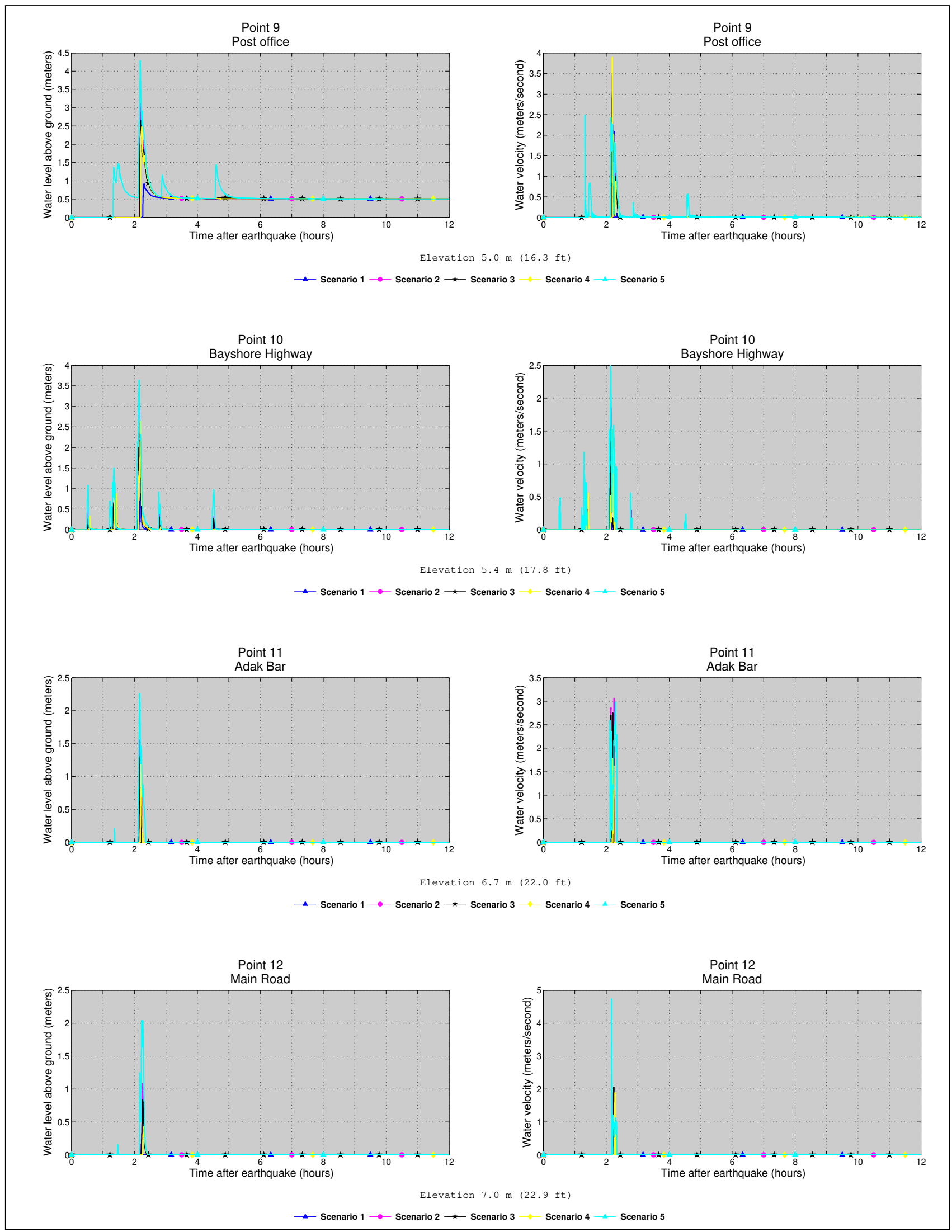

Figure A2, continued. Time series of water level (left) and velocity (right) for scenarios 1-5 at Adak locations shown in figure A1. The pre-earthquake elevation/depth with respect to the $\mathrm{MHHW}$ is stated for each location. For offshore locations, to show the height of an arriving tsunami, the vertical datum is such that zero corresponds to the pre-earthquake sea level. 


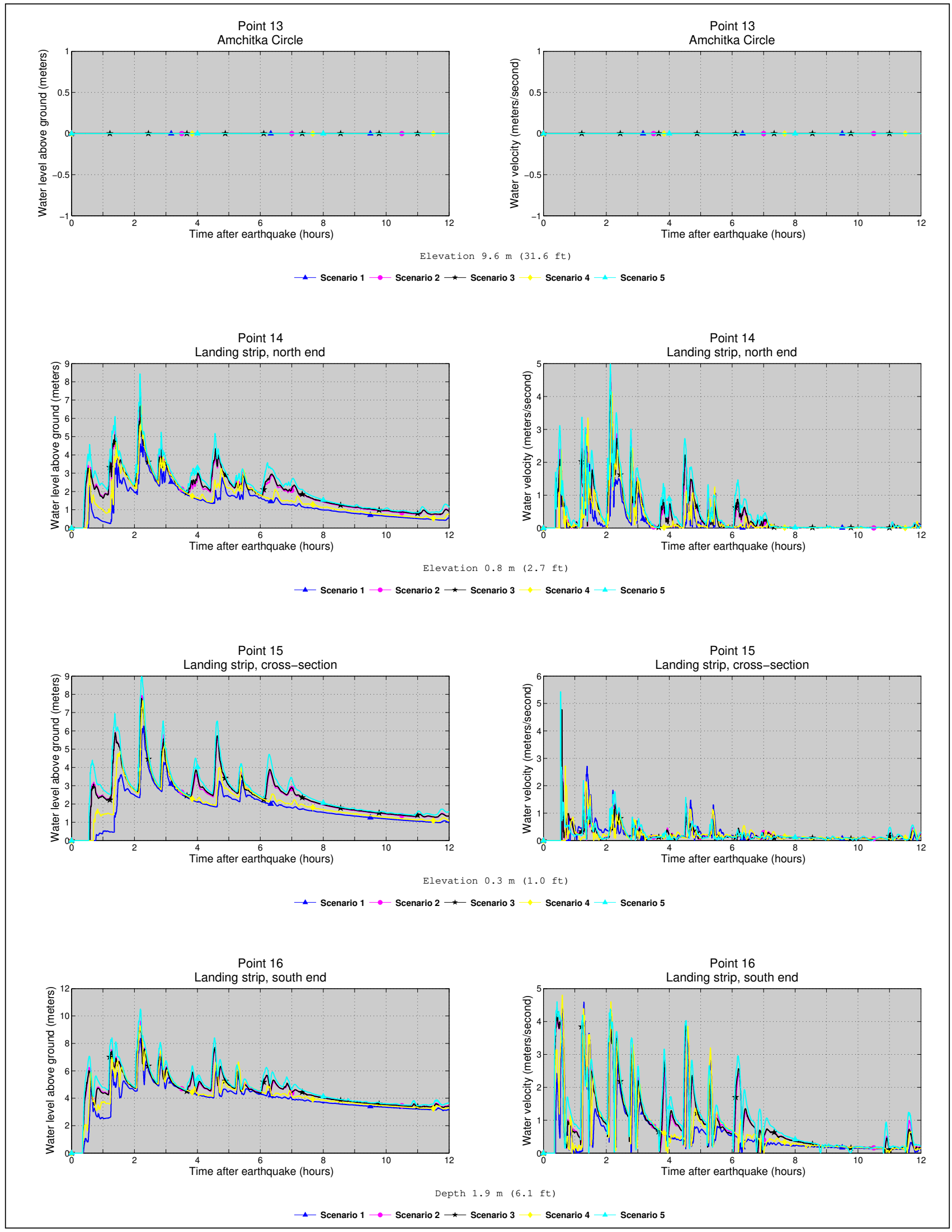

Figure A2, continued. Time series of water level (left) and velocity (right) for scenarios 1-5 at Adak locations shown in figure A1. The pre-earthquake elevation/depth with respect to the $\mathrm{MHHW}$ is stated for each location. For offshore locations, to show the height of an arriving tsunami, the vertical datum is such that zero corresponds to the pre-earthquake sea level. 


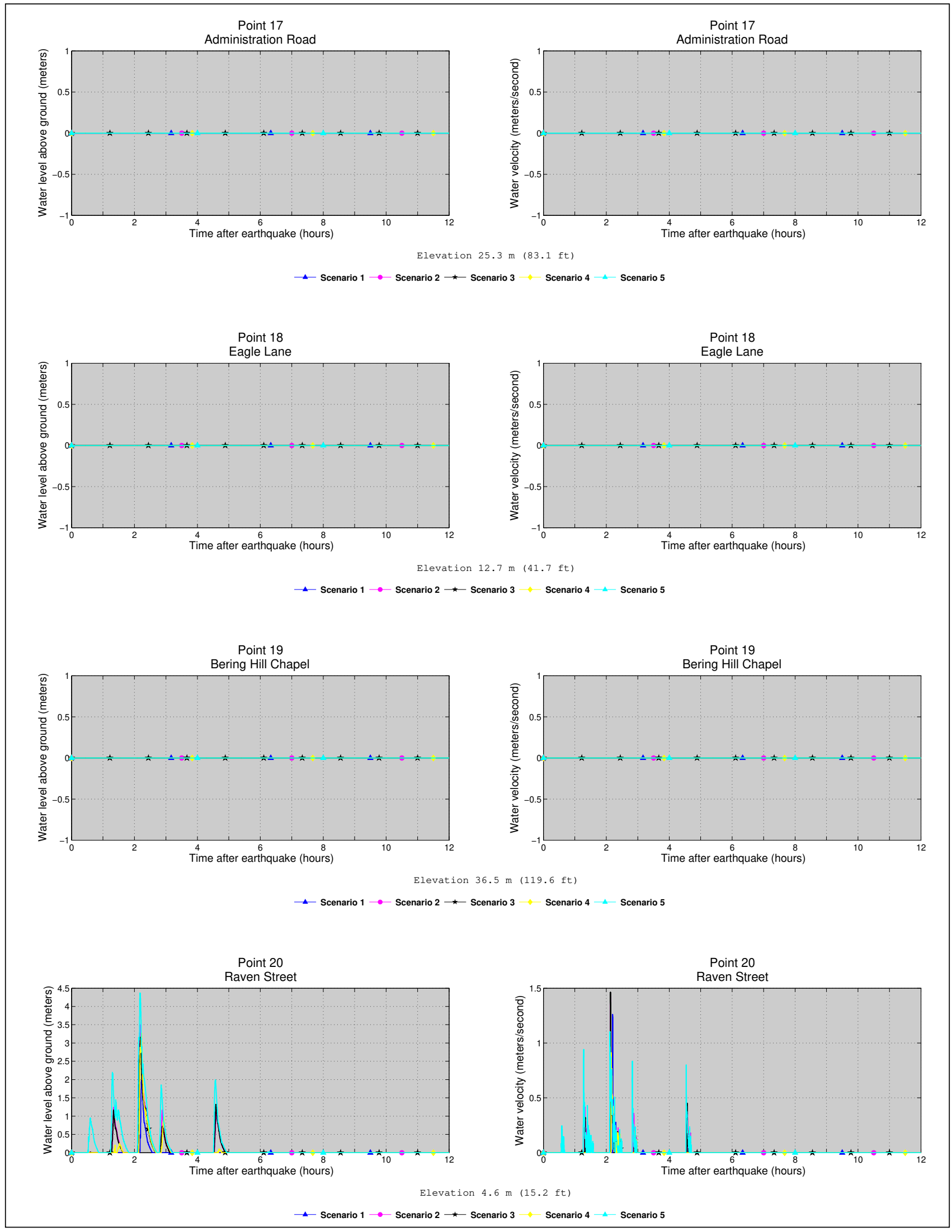

Figure A2, continued. Time series of water level (left) and velocity (right) for scenarios 1-5 at Adak locations shown in figure A1. The pre-earthquake elevation/depth with respect to the $\mathrm{MHHW}$ is stated for each location. For offshore locations, to show the height of an arriving tsunami, the vertical datum is such that zero corresponds to the pre-earthquake sea level. 


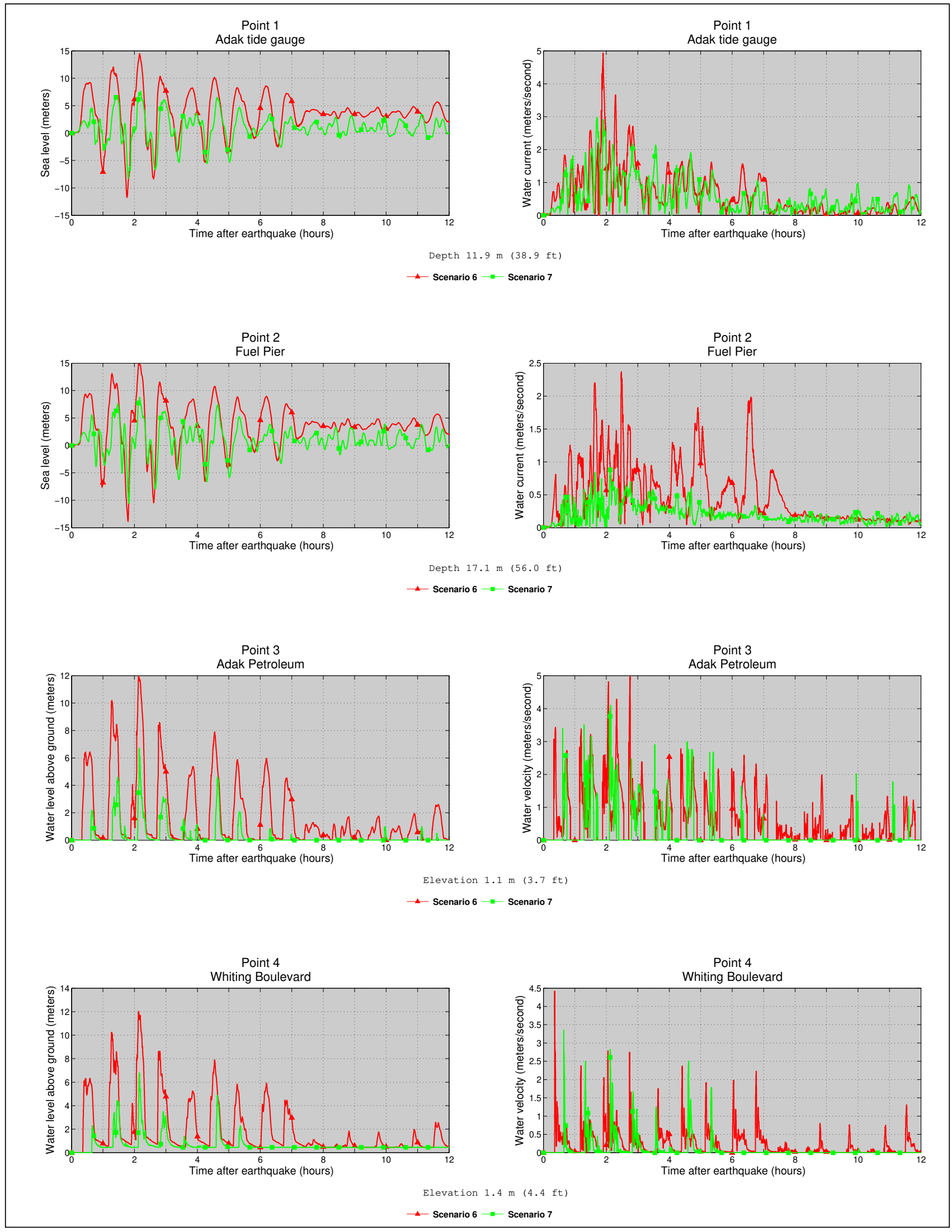

Figure A3. Time series of water level (left) and velocity (right) for scenarios 6 and 7 at Adak locations shown in figure A1. The pre-earthquake elevation/depth with respect to the $\mathrm{MHHW}$ is stated for each location. For offshore locations, to show the height of an arriving tsunami, the vertical datum is such that zero corresponds to the pre-earthquake sea level. 


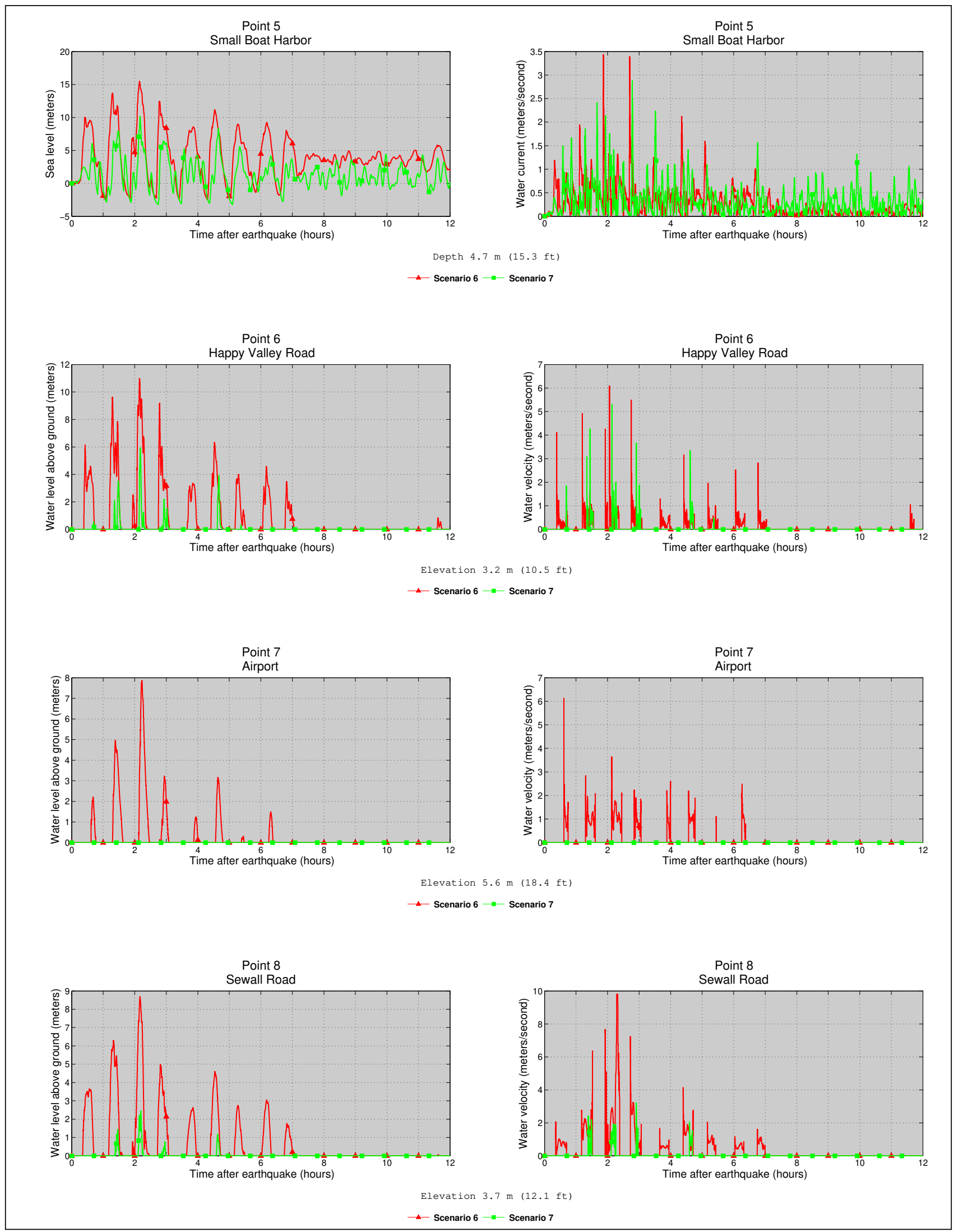

Figure A3, continued. Time series of water level (left) and velocity (right) for scenarios 6 and 7 at Adak locations shown in figure A1. The pre-earthquake elevation/depth with respect to the $\mathrm{MHHW}$ is stated for each location. For offshore locations, to show the height of an arriving tsunami, the vertical datum is such that zero corresponds to the pre-earthquake sea level. 


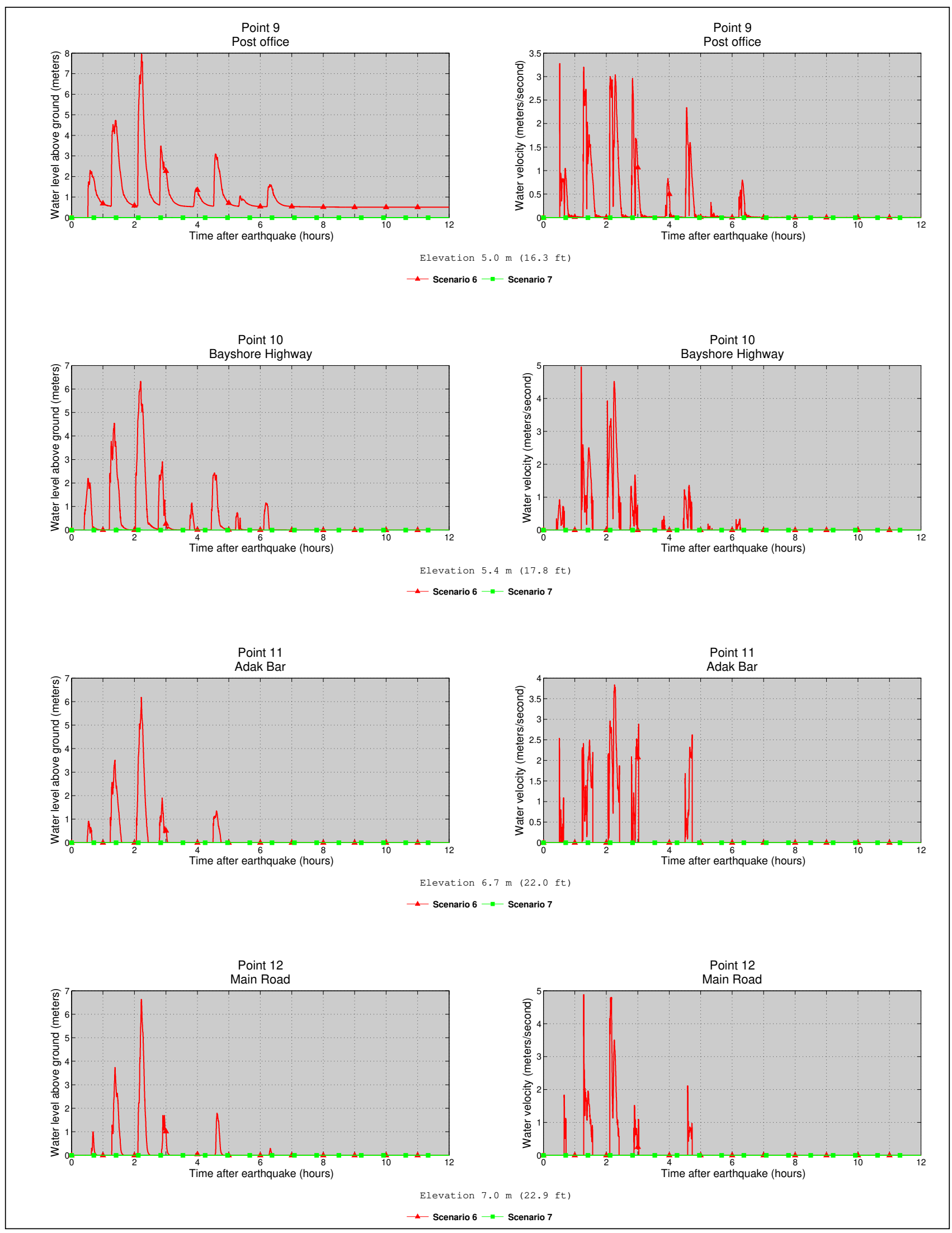

Figure A3, continued. Time series of water level (left) and velocity (right) for scenarios 6 and 7 at Adak locations shown in figure A1. The pre-earthquake elevation/depth with respect to the $\mathrm{MHHW}$ is stated for each location. For offshore locations, to show the height of an arriving tsunami, the vertical datum is such that zero corresponds to the pre-earthquake sea level. 


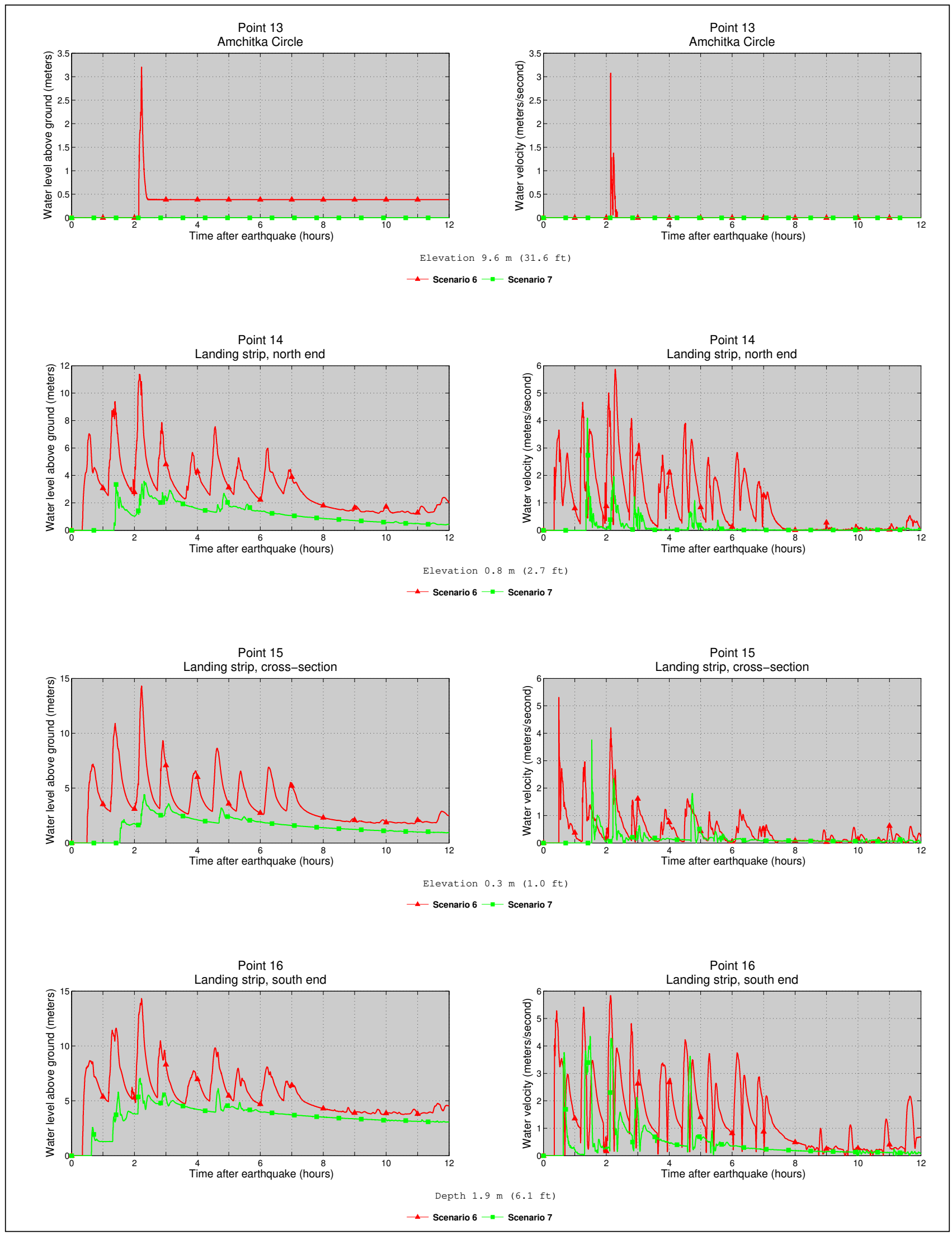

Figure A3, continued. Time series of water level (left) and velocity (right) for scenarios 6 and 7 at Adak locations shown in figure A1. The pre-earthquake elevation/depth with respect to the $\mathrm{MHHW}$ is stated for each location. For offshore locations, to show the height of an arriving tsunami, the vertical datum is such that zero corresponds to the pre-earthquake sea level. 


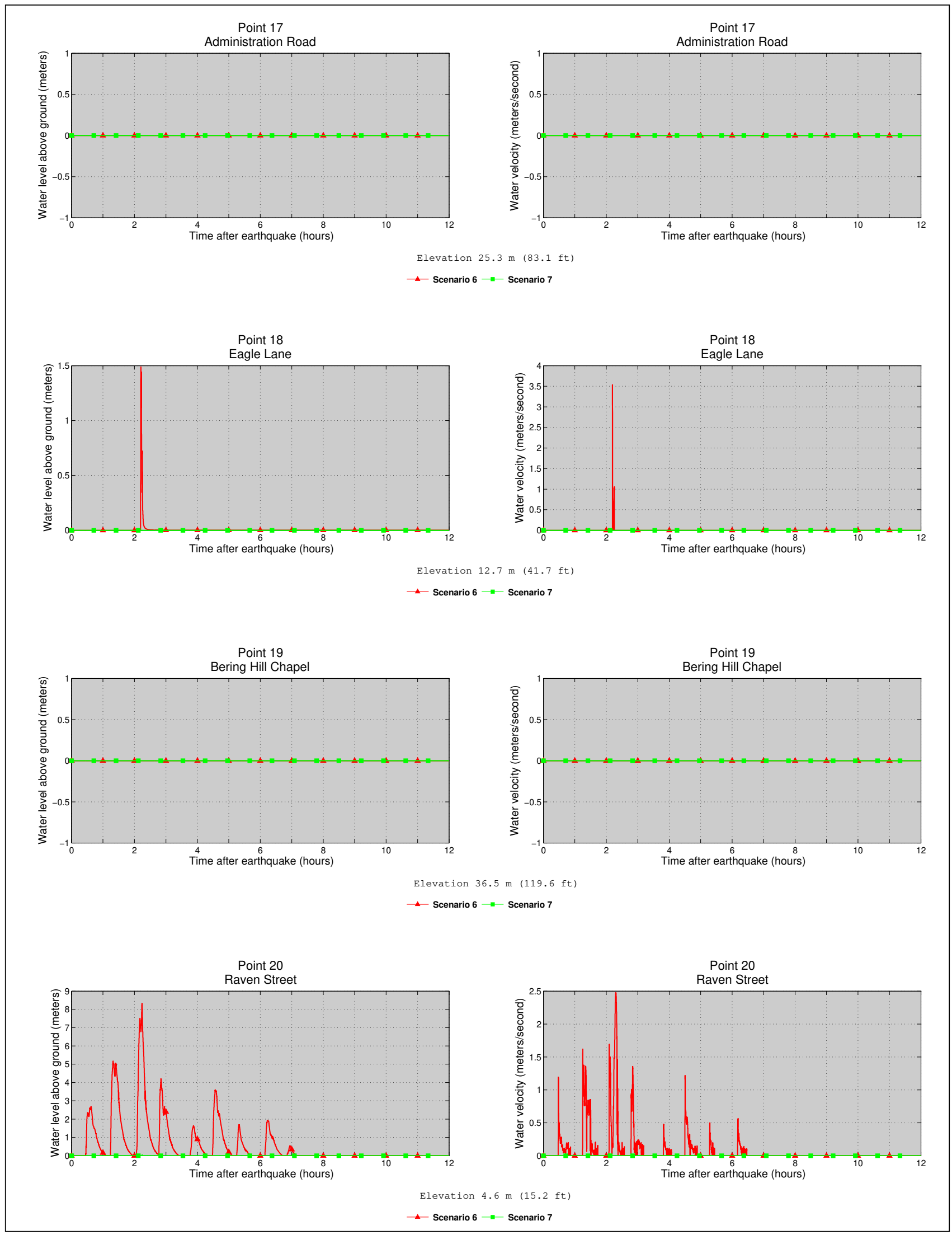

Figure A3, continued. Time series of water level (left) and velocity (right) for scenarios 6 and 7 at Adak locations shown in figure A1. The pre-earthquake elevation/depth with respect to the $\mathrm{MHHW}$ is stated for each location. For offshore locations, to show the height of an arriving tsunami, the vertical datum is such that zero corresponds to the pre-earthquake sea level. 


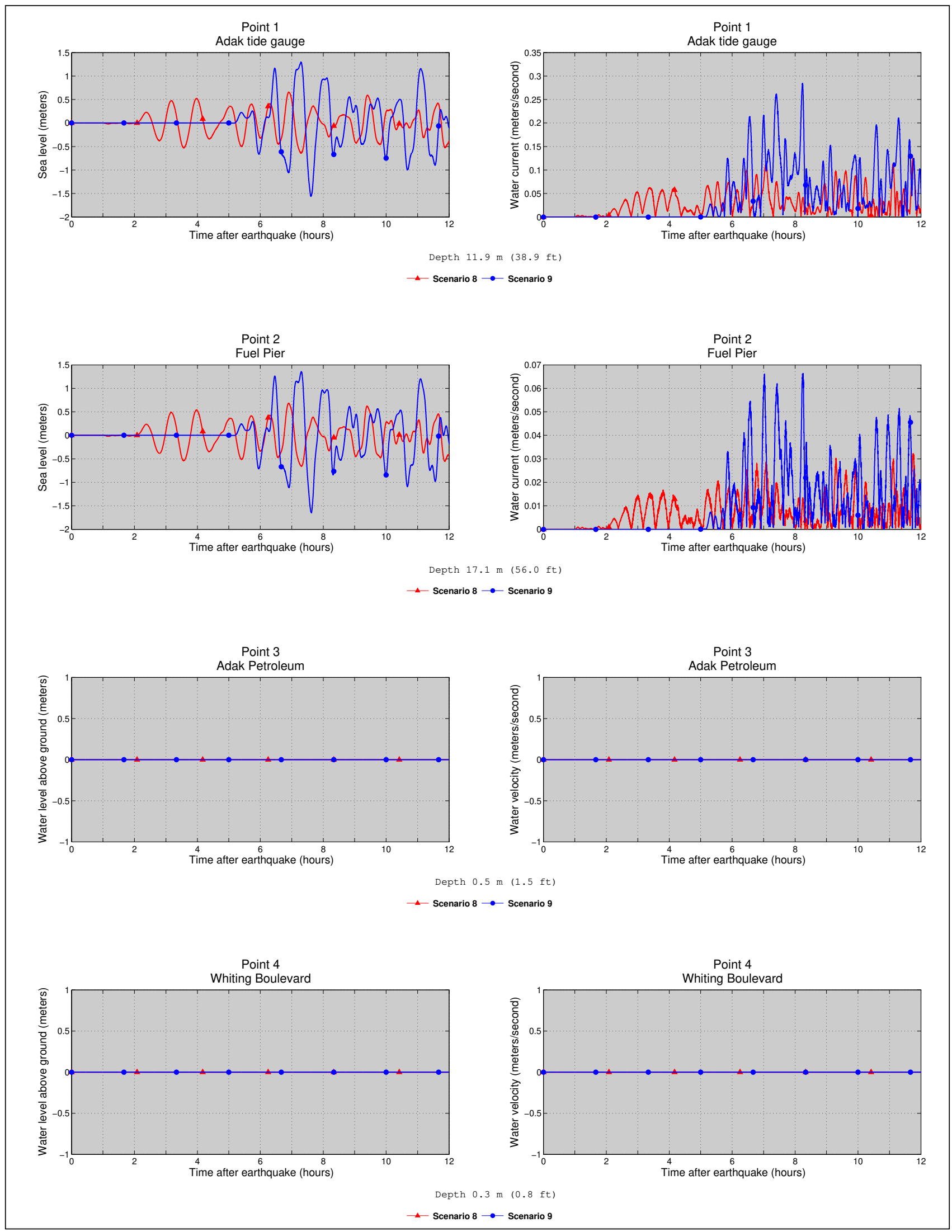

Figure A4. Time series of water level (left) and velocity (right) for scenarios 8 and 9 at Adak locations shown in figure A1. The pre-earthquake elevation/depth with respect to the $\mathrm{MHHW}$ is stated for each location. For offshore locations, to show the height of an arriving tsunami, the vertical datum is such that zero corresponds to the pre-earthquake sea level. 


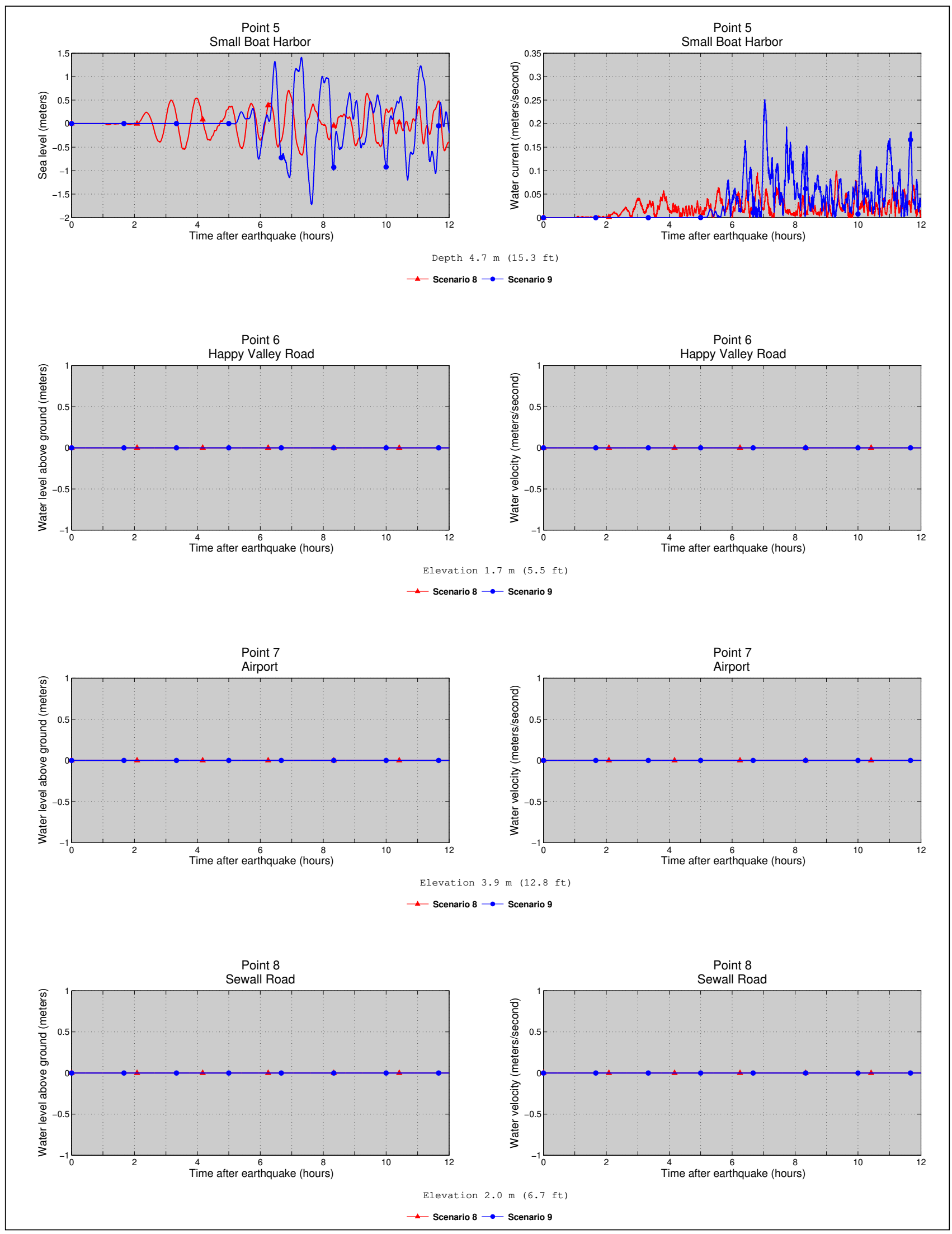

Figure A4, continued. Time series of water level (left) and velocity (right) for scenarios 8 and 9 at Adak locations shown in figure A1. The pre-earthquake elevation/depth with respect to the $\mathrm{MHHW}$ is stated for each location. For offshore locations, to show the height of an arriving tsunami, the vertical datum is such that zero corresponds to the pre-earthquake sea level. 


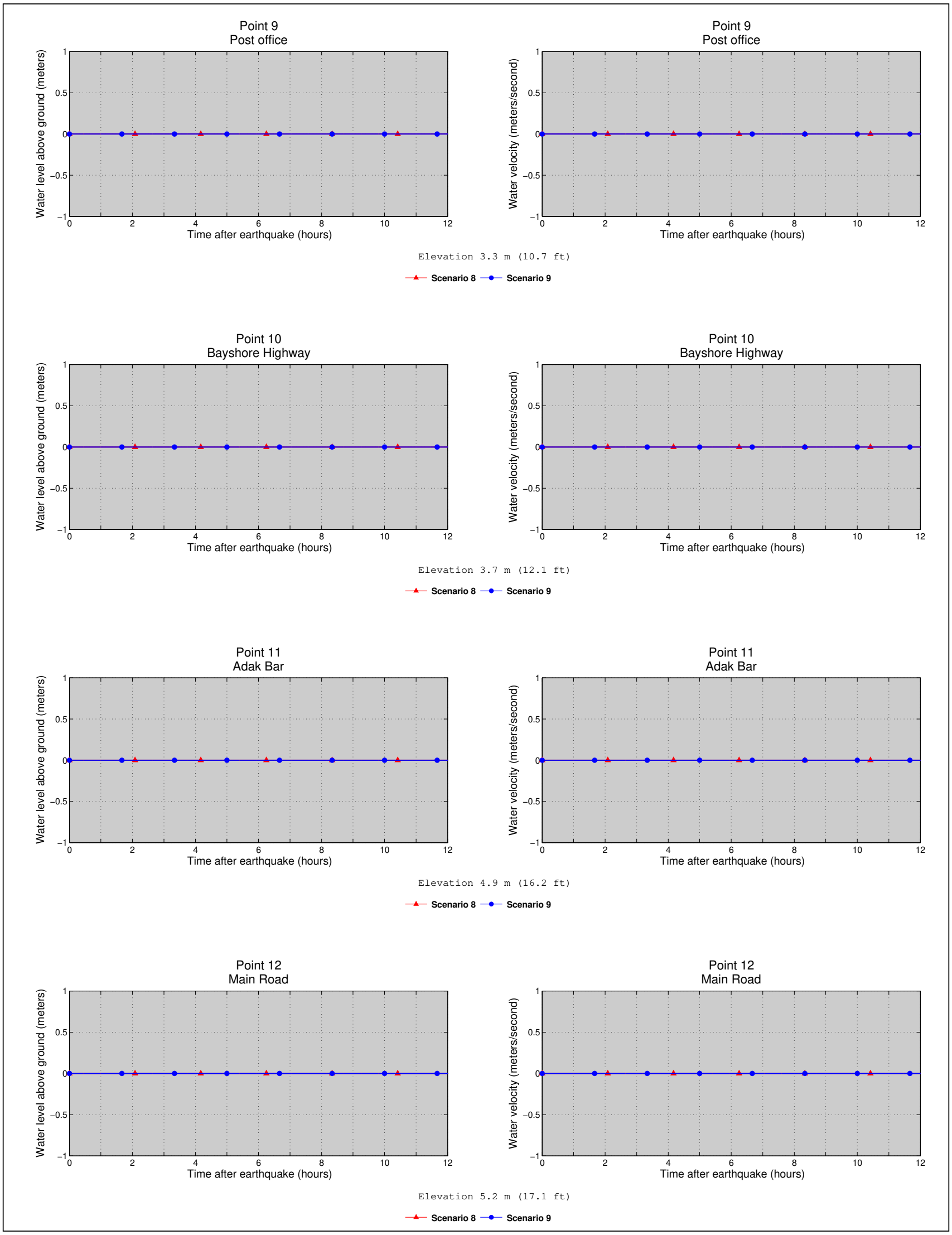

Figure A4, continued. Time series of water level (left) and velocity (right) for scenarios 8 and 9 at Adak locations shown in figure A1. The pre-earthquake elevation/depth with respect to the $\mathrm{MHHW}$ is stated for each location. For offshore locations, to show the height of an arriving tsunami, the vertical datum is such that zero corresponds to the pre-earthquake sea level. 


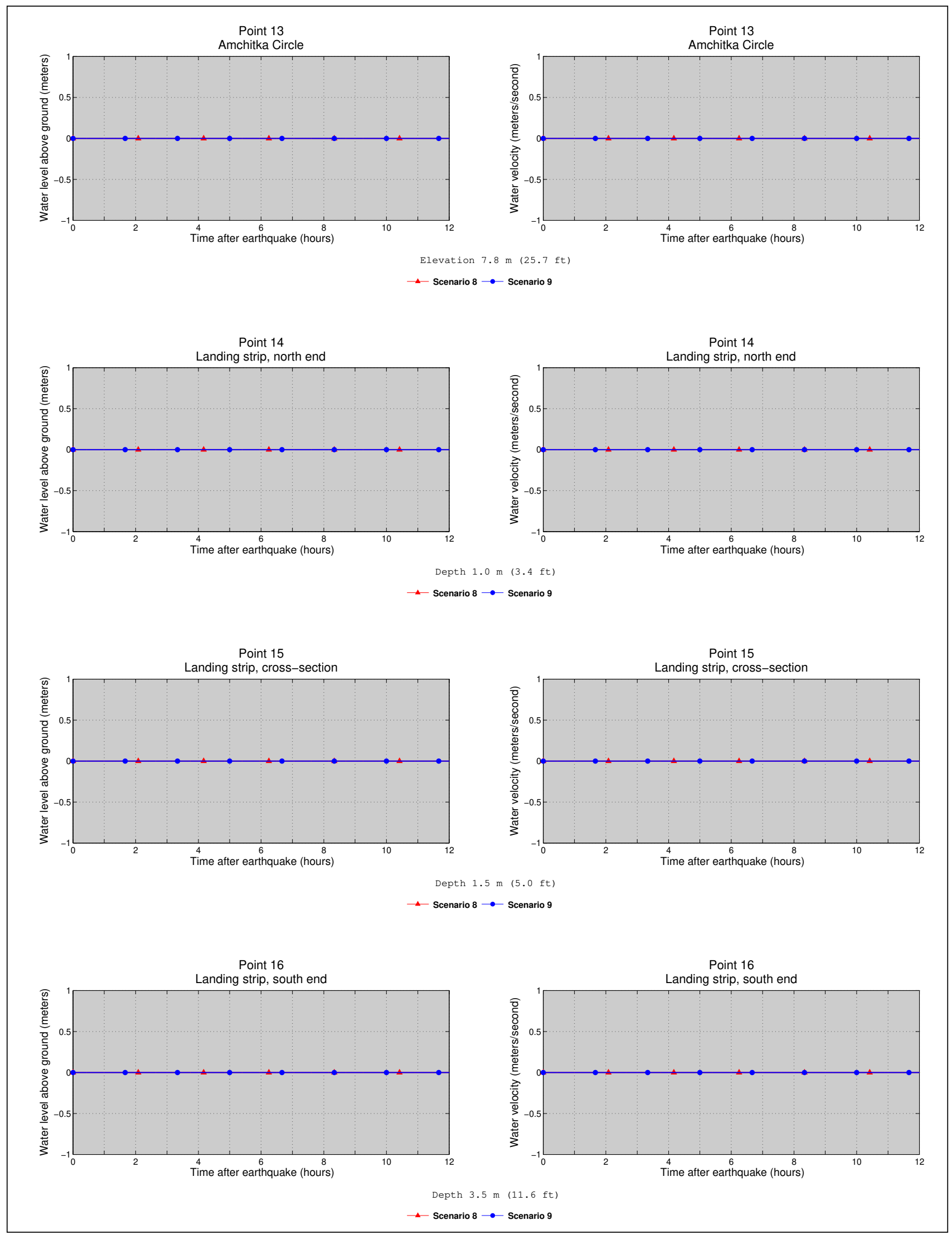

Figure A4, continued. Time series of water level (left) and velocity (right) for scenarios 8 and 9 at Adak locations shown in figure A1. The pre-earthquake elevation/depth with respect to the $\mathrm{MHHW}$ is stated for each location. For offshore locations, to show the height of an arriving tsunami, the vertical datum is such that zero corresponds to the pre-earthquake sea level. 


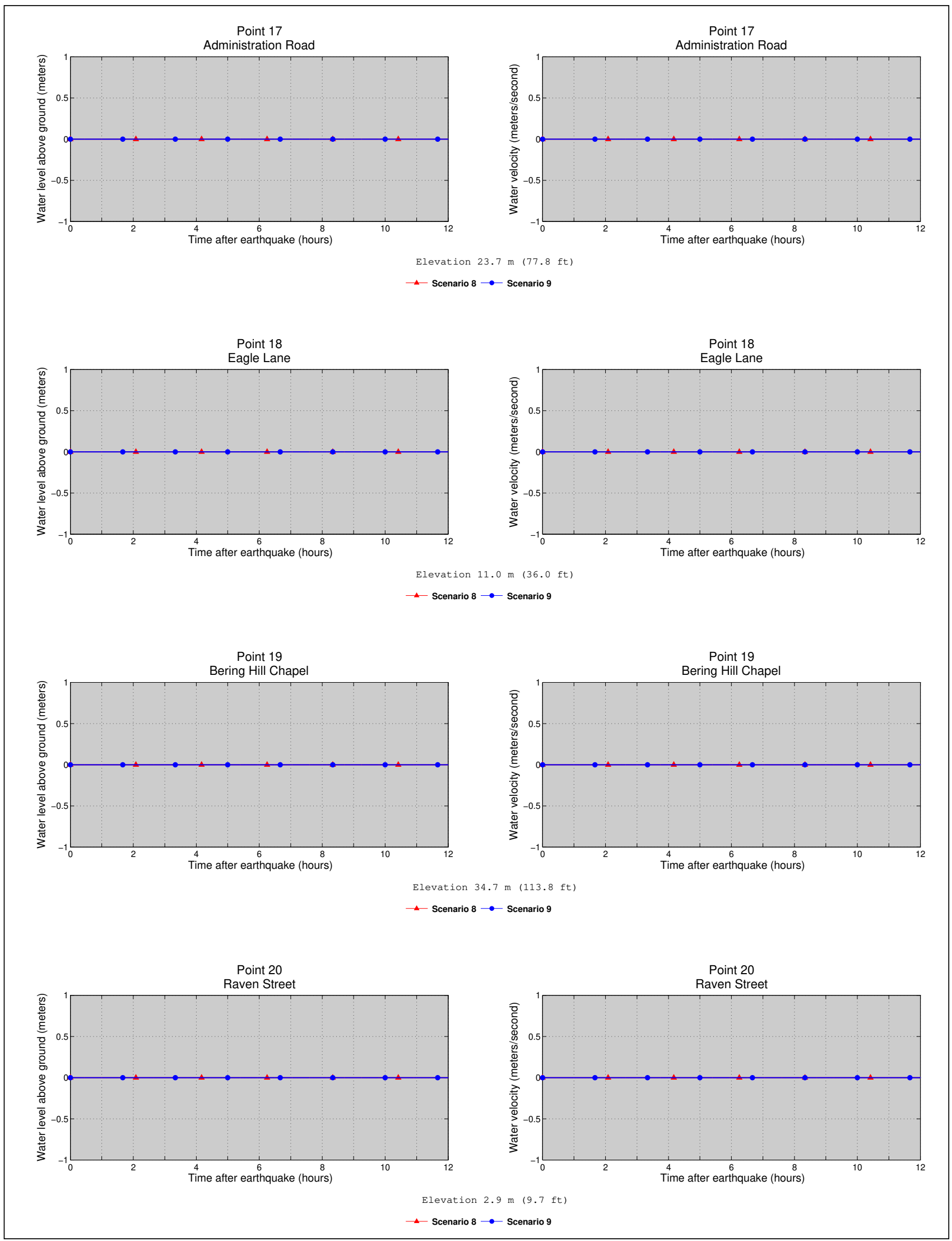

Figure A4, continued. Time series of water level (left) and velocity (right) for scenarios 8 and 9 at Adak locations shown in figure A1. The pre-earthquake elevation/depth with respect to the $\mathrm{MHHW}$ is stated for each location. For offshore locations, to show the height of an arriving tsunami, the vertical datum is such that zero corresponds to the pre-earthquake sea level. 


\section{APPENDIX B}

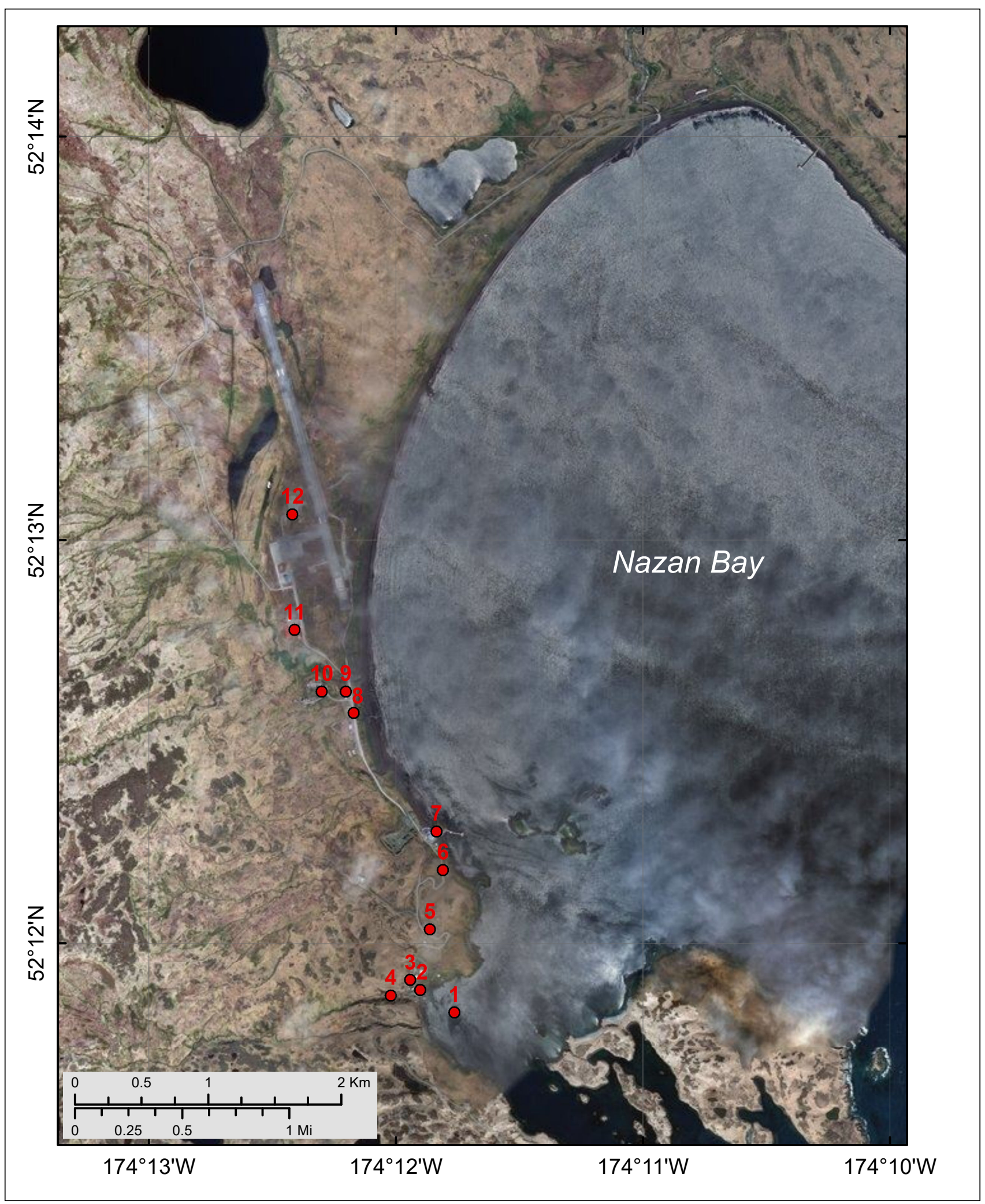

Figure B1. Locations of time series points in Atka. The longitudinal and latitudinal coordinates of the time series points are listed in table B1. 


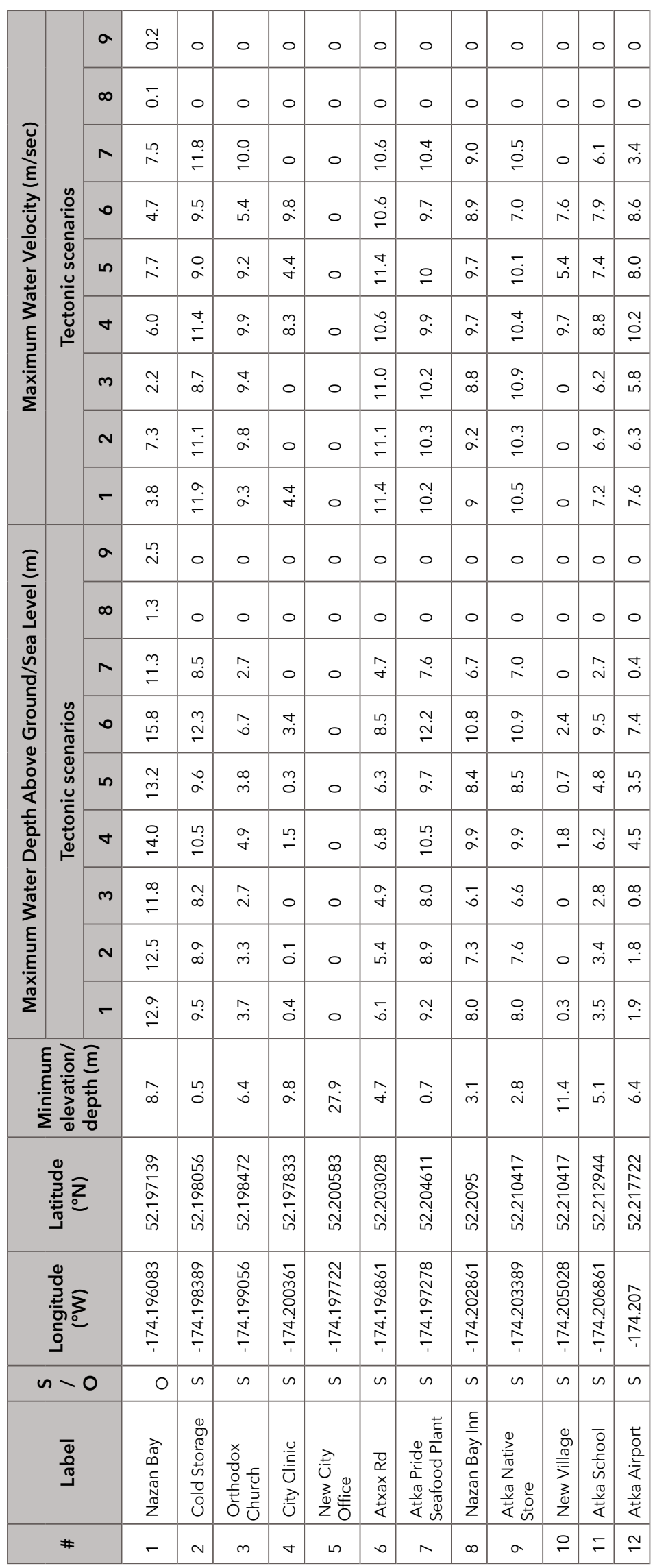




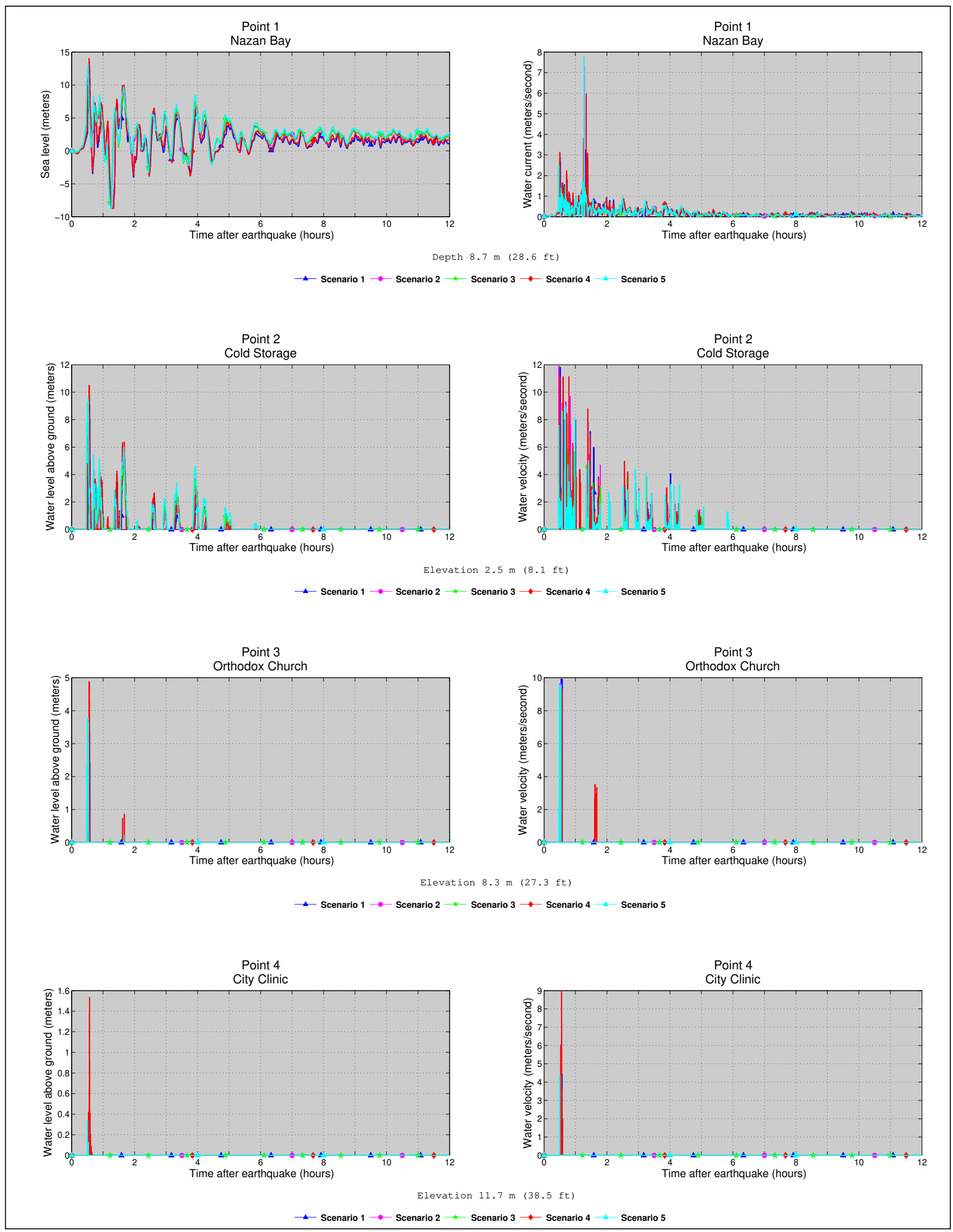

Figure B2. Time series of water level (left) and velocity (right) for scenarios 1-5 at Atka locations shown in figure B1. The pre-earthquake elevation/depth with respect to the MHHW is stated for each location. For offshore locations, to show the height of an arriving tsunami, the vertical datum is such that zero corresponds to the pre-earthquake sea level. 


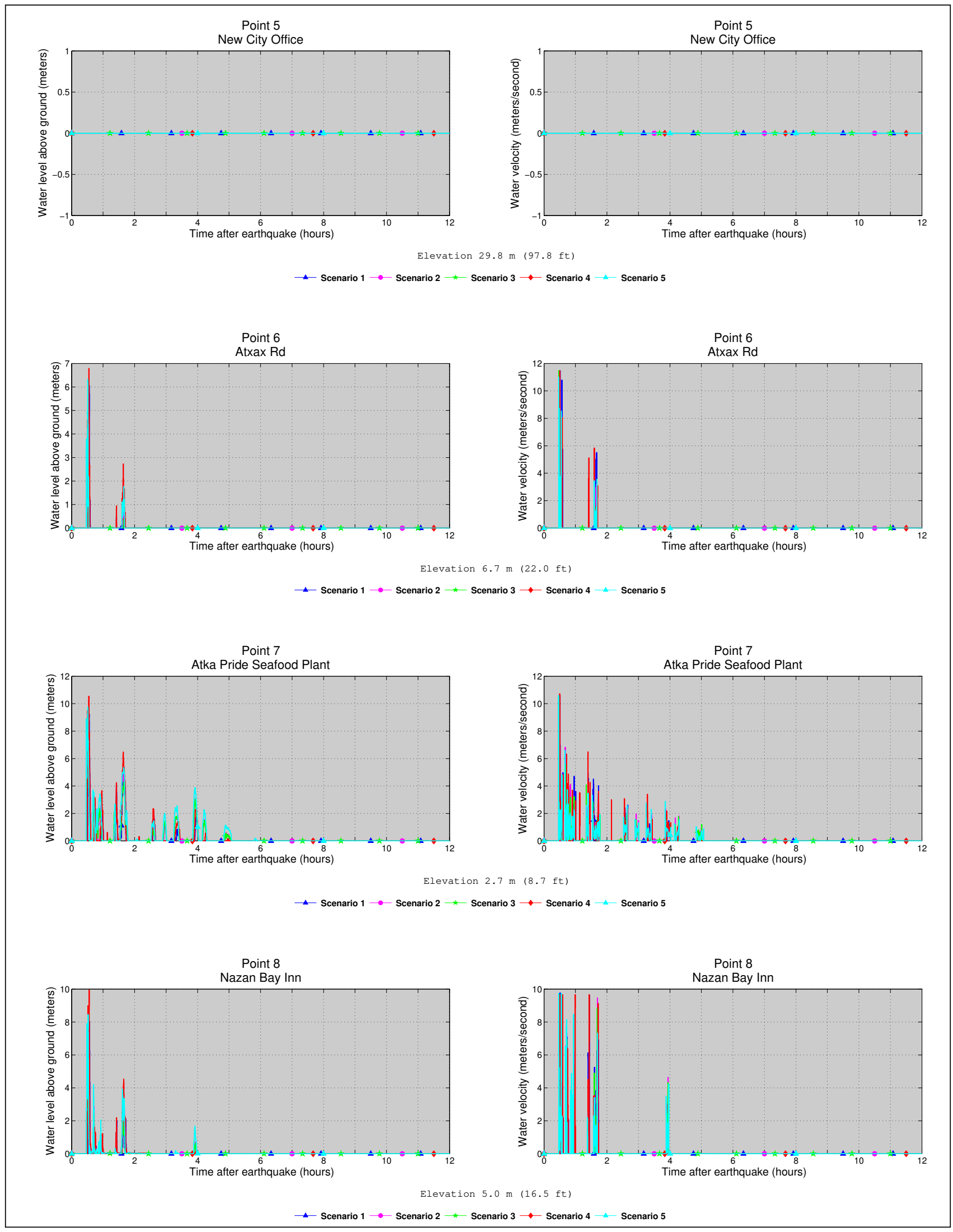

Figure B2, continued. Time series of water level (left) and velocity (right) for scenarios 1-5 at Atka locations shown in figure B1. The pre-earthquake elevation/depth with respect to the $\mathrm{MHHW}$ is stated for each location. For offshore locations, to show the height of an arriving tsunami, the vertical datum is such that zero corresponds to the pre-earthquake sea level. 


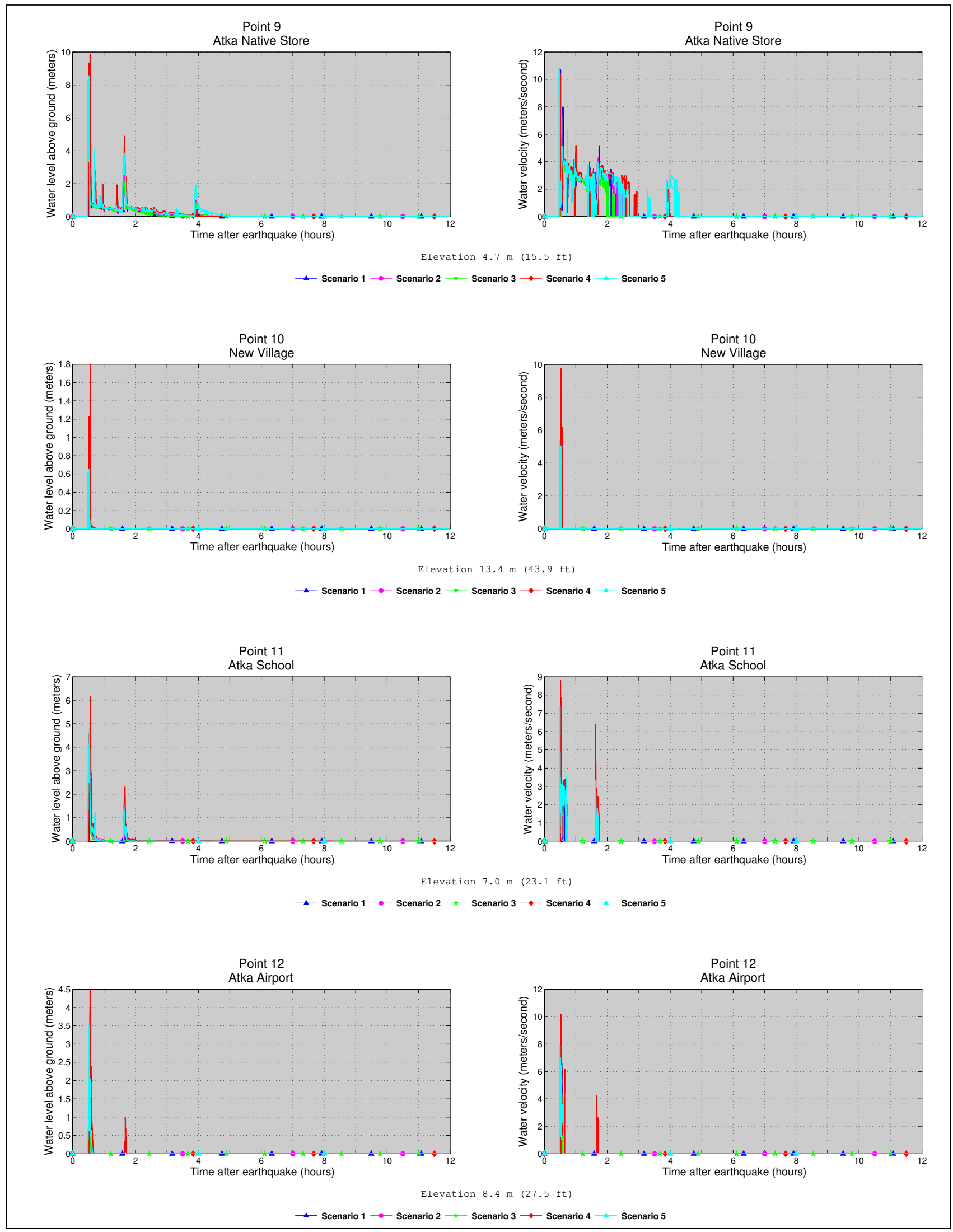

Figure B2, continued. Time series of water level (left) and velocity (right) for scenarios 1-5 at Atka locations shown in figure B1. The pre-earthquake elevation/depth with respect to the $\mathrm{MHHW}$ is stated for each location. For offshore locations, to show the height of an arriving tsunami, the vertical datum is such that zero corresponds to the pre-earthquake sea level. 


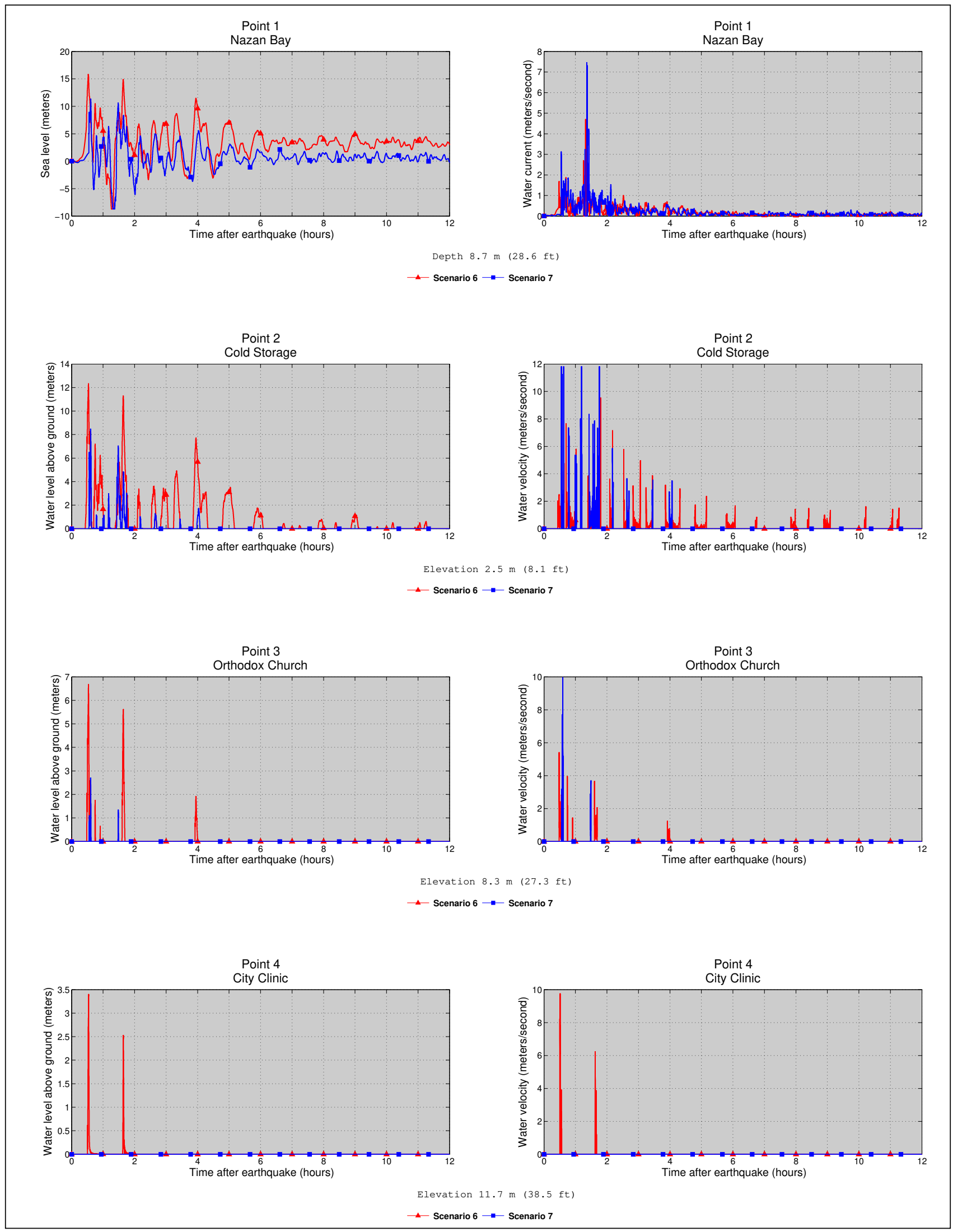

Figure B3. Time series of water level (left) and velocity (right) for scenarios 6-7 at Atka locations shown in figure B1. The pre-earthquake elevation/depth with respect to the $\mathrm{MHHW}$ is stated for each location. For offshore locations, to show the height of an arriving tsunami, the vertical datum is such that zero corresponds to the pre-earthquake sea level. 


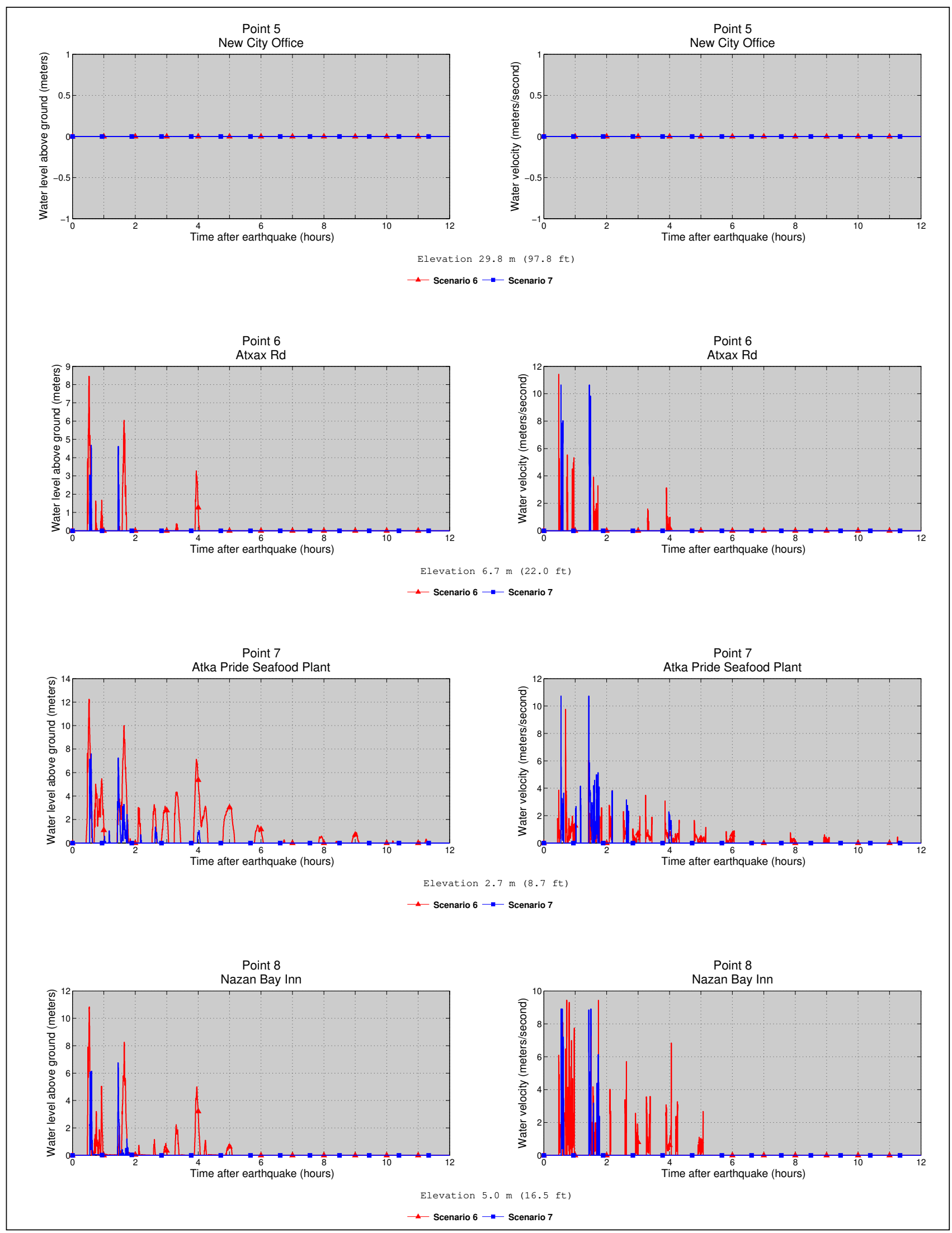

Figure B3, continued. Time series of water level (left) and velocity (right) for scenarios 6-7 at Atka locations shown in figure B1. The pre-earthquake elevation/depth with respect to the $\mathrm{MHHW}$ is stated for each location. For offshore locations, to show the height of an arriving tsunami, the vertical datum is such that zero corresponds to the pre-earthquake sea level. 


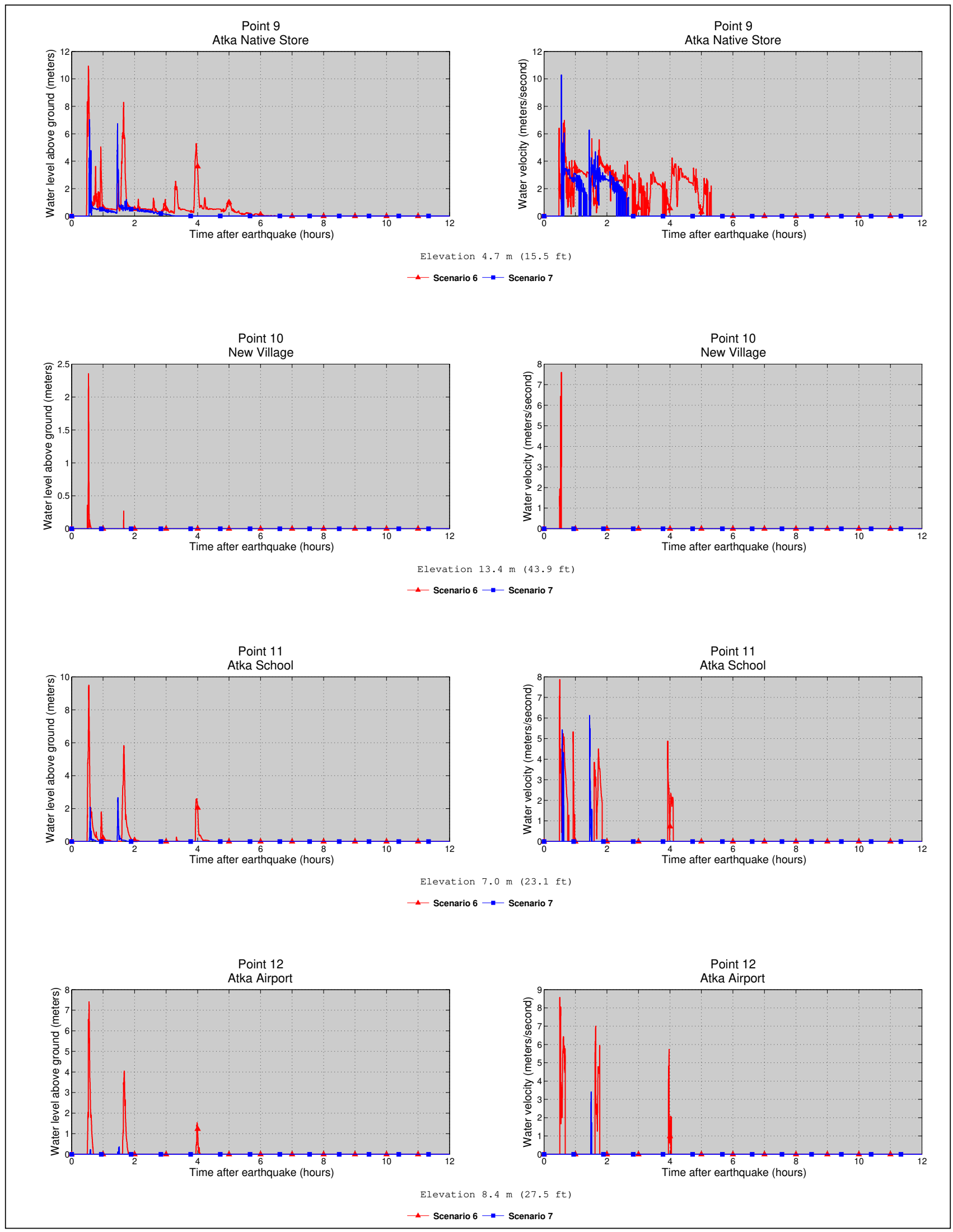

Figure B3, continued. Time series of water level (left) and velocity (right) for scenarios 6-7 at Atka locations shown in figure $\mathrm{B} 1$. The pre-earthquake elevation/depth with respect to the $\mathrm{MHHW}$ is stated for each location. For offshore locations, to show the height of an arriving tsunami, the vertical datum is such that zero corresponds to the pre-earthquake sea level. 


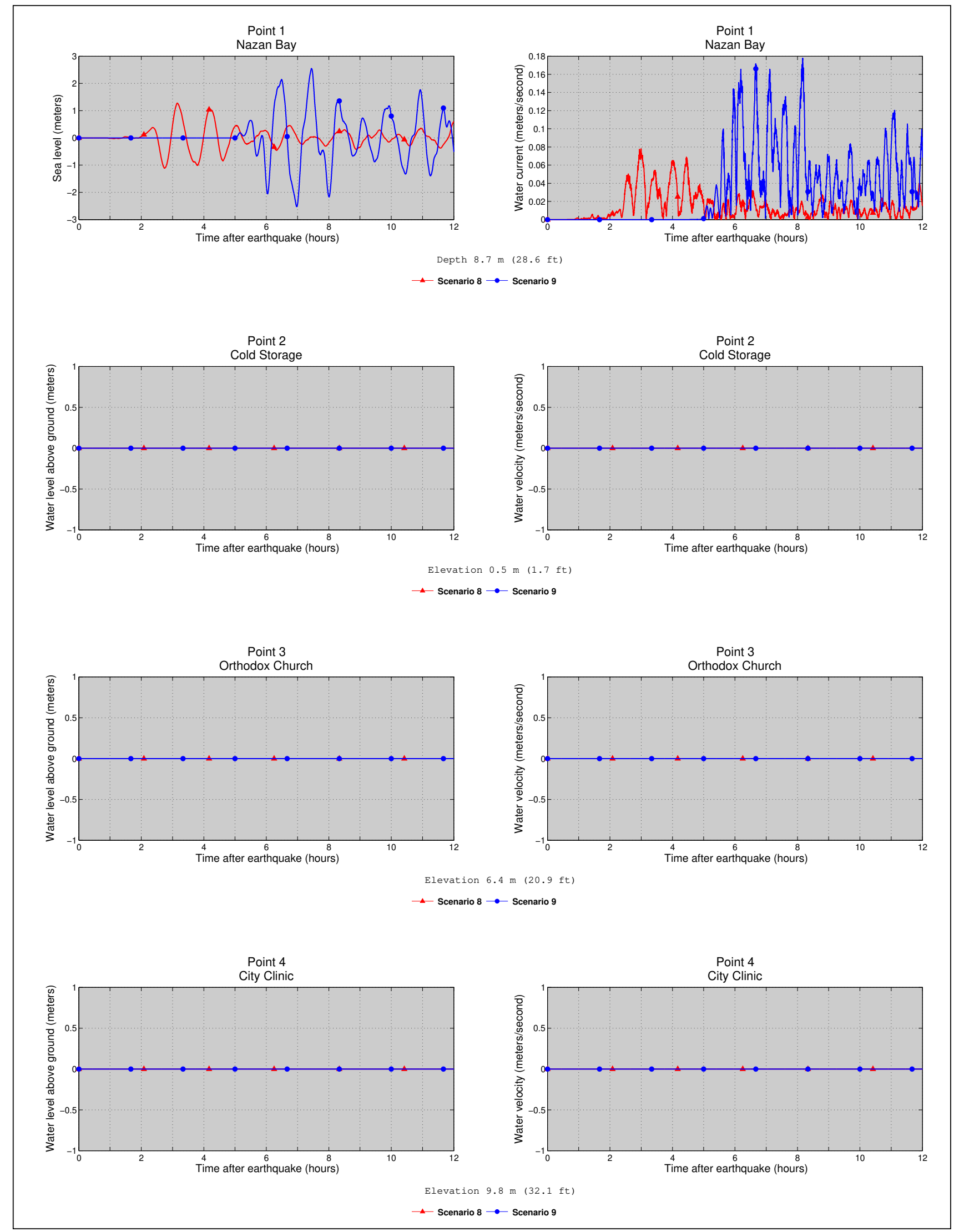

Figure B4. Time series of water level (left) and velocity (right) for scenarios 8 and 9 at Atka locations shown in figure B1. The pre-earthquake elevation/depth with respect to the MHHW is stated for each location. For offshore locations, to show the height of an arriving tsunami, the vertical datum is such that zero corresponds to the pre-earthquake sea level. 


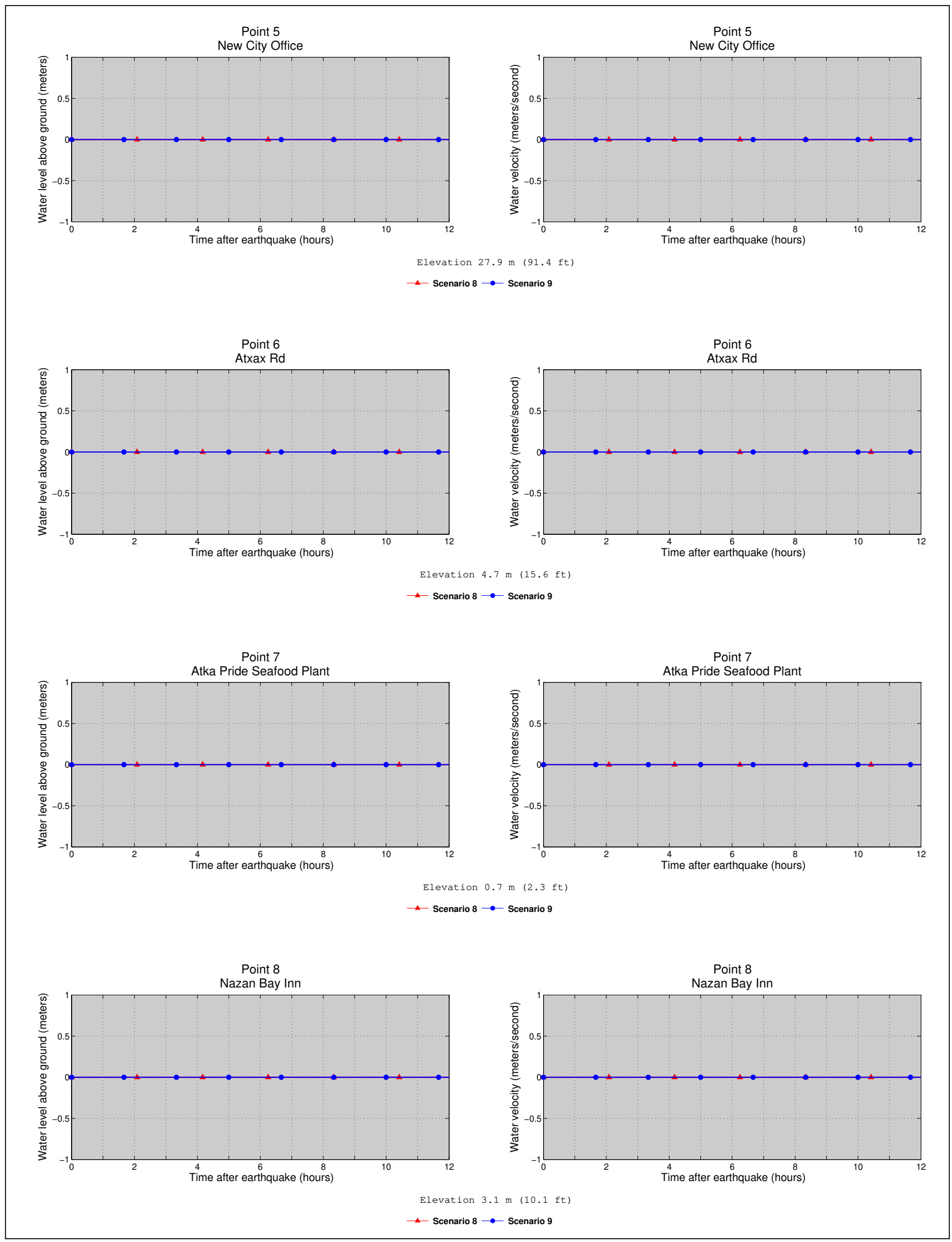

Figure B4, continued. Time series of water level (left) and velocity (right) for scenarios 8 and 9 at Atka locations shown in figure B1. The pre-earthquake elevation/depth with respect to the MHHW is stated for each location. For offshore locations, to show the height of an arriving tsunami, the vertical datum is such that zero corresponds to the pre-earthquake sea level. 


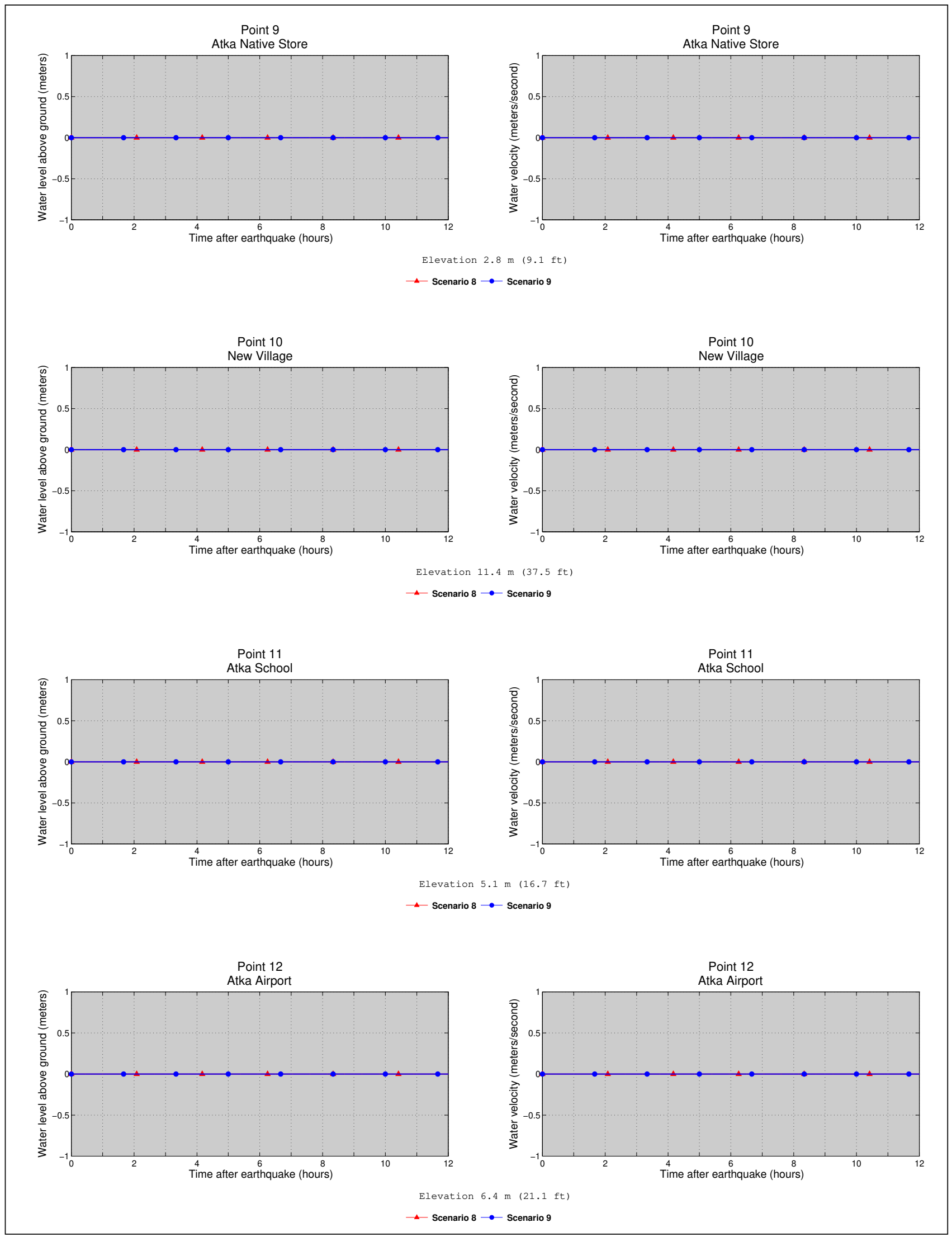

Figure B4, continued. Time series of water level (left) and velocity (right) for scenarios 8 and 9 at Atka locations shown in figure B1. The pre-earthquake elevation/depth with respect to the MHHW is stated for each location. For offshore locations, to show the height of an arriving tsunami, the vertical datum is such that zero corresponds to the pre-earthquake sea level. 